\title{
SOURCES OF SELECTED CHEMICAL COMPONENTS IN ATMOSPHERIC AEROSOLS IN FINLAND
}
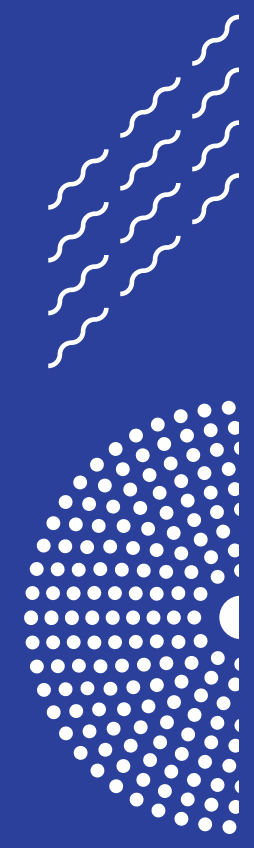
FINNISH METEOROLOGICAL INSTITUTE

CONTRIBUTIONS

No. 178

\title{
Sources of Selected Chemical Components in Atmospheric Aerosols in Finland
}

\author{
Mika Vestenius \\ Department of Chemistry \\ Faculty of Science \\ University of Helsinki \\ Helsinki, Finland
}

ACADEMIC DISSERTATION in chemistry

To be presented, with the permission of the Faculty of Science of the University of Helsinki, for public criticism, in Finnish Meteorological Institute Brainstorm auditorium at Dynamicum (Erik Palménin Aukio 1, Helsinki) on October 29, 2021, at 12 noon.

Finnish Meteorological Institute

Helsinki, 2021 
Author's address: Mika Vestenius

Finnish Meteorological Institute (FMI)

P.O. Box 503, FI-00101 Helsinki, Finland

mika.vestenius@fmi.fi

Supervisors

Research Professor Hannele Hakola

Atmospheric Composition Research

Finnish Meteorological Institute, Finland

Dr. Heidi Hellén

Atmospheric Composition Research

Finnish Meteorological Institute, Finland

Reviewers Associate Professor Topi Rönkkö

Aerosol Physics Laboratory

Tampere University, Finland

Docent Jorma Joutsensaari

Aerosol Physics Group

University of Eastern Finland, Kuopio, Finland

Custos Professor Marja-Liisa Riekkola

Department of Chemistry

University of Helsinki, Finland

Opponent

Associate Professor Marianne Glasius

Department of Chemistry

Aarhus University, Denmark

FINNISH METEOROLOGICAL INSTITUTE CONTRIBUTIONS No. 178

ISSN 0782-6117

ISBN 978-952-336-147-8 (paperback)

ISBN 978-952-336-146-1 (pdf)

https://doi.org/10.35614/isbn.9789523361461

http://ethesis.helsinki.fi

Helsingin yliopiston digitaaliset opinnäytteet

Helsinki 2021

Helsinki, 2021 Edita Prima Oy 


\section{Published by: Finnish Meteorological Institute}

(Erik Palménin aukio 1), P.O. Box 503

FIN-00101 Helsinki, Finland

\section{Author}

Mika Vestenius

Title

Sources of Selected Chemical Components in Atmospheric Aerosols in Finland
Finnish Meteorological Institute, Contributions No. 178

Date: October 2021

\begin{abstract}
Air pollution is an important environmental risk to human health and ecosystems around the world. Particulate matter (PM), especially fine particulate matter, is an important part of this air pollution problem. Particle composition varies greatly and depends on the emission source. In addition to inorganic components, organic particulate fraction can contain several hundred organic compounds from anthropogenic and natural sources. The health risk of particulate is related to the particle size and the compounds inside or on the surface of the aerosol particles.
\end{abstract}

The overall aim of this thesis was to study the selected chemical substances of atmospheric aerosol from both anthropogenic and natural sources. Concentrations of polycyclic aromatic hydrocarbons (PAH) and biogenic organic acids in aerosol were measured, and their effect on the local air quality was estimated. The sources of PAHs, trace elements, biogenic volatile organic compounds (BVOCs), and persistent organic compounds (POPs) in air were studied using positive matrix factorization (PMF), which was used as the main source apportionment tool in three of five papers and for the unpublished data in this thesis.

Particles from burning emissions, e.g., diesel particles and particles from biomass burning, are the most toxic in our daily environment. Because of intensive wood use for heating and in sauna stoves, residential biomass burning is the major PAH air pollution source in Finland. Sources of atmospheric PAH pollution and its influence on local air quality were estimated at Virolahti background air quality station and in the Helsinki Metropolitan Area (HMA). The main source of PAHs at Virolahti were found to be combustion- and traffic-related source from the direction of St. Petersburg. Instead, local traffic appeared to have a very small influence on PAH levels in HMA, as local residential wood burning was found to be the main b(a)p source in Helsinki Metropolitan Area.

Biogenic VOCs like monoterpenes and sesquiterpenes are highly reactive and oxidize rapidly in the atmosphere, producing secondary organic aerosol (SOA). We showed that positive matrix factorization (PMF) is a useful tool in estimating separate sources in a quasistationary dynamic system like ambient VOC concentrations in the boreal forest. Selected biogenic organic acids were measured from fine particles in the boreal forest in order to estimate their influence on aerosol production. Results indicated that sesquiterpene emissions from boreal forest are probably underestimated and their oxidation products probably have more important role in the SOA production that previously estimated.

The Kola Peninsula area was found to be the major source of heavy metal pollution at Pallas. However, as Norilsk Nickel has now partly shut down its metallurgical operations, the trace element and $\mathrm{SO}_{2}$ emissions from the Kola Peninsula should be declining in the future.

The ambient concentrations of POP compounds are globally declining but, in the Arctic, for some compounds this is not the case. In the source apportionment study for Pallas 1996-2018 POPs data, relatively big portion of measured POPs at Pallas came within the marine source from clean areas from the north. These long-lived compounds, which have migrated into the Arctic from the southern areas along the air and sea currents for many decades, are now released back into the atmosphere from the melting Arctic ice cover due to global warming. For these compounds, the Arctic has turned from the sink to the source.

Publishing unit

Finnish Meteorological Institute, Atmospheric Composition Unit

Classification (UDC)

502.3:613.15; 543.275; 661.715;

$551.510 .4 ; 614.71$

Keywords

air quality, atmospheric aerosols, hydrocarbons, chemical composition, atmosphere, air pollution, polycyclic aromatic hydrocarbons, persistent organic pollutants, PM, measurements, monitoring, source apportionment, organic aerosols

ISSN 0782-6117

ISBN 978-952-336-146-1 (pdf)

DOI: https://doi.org/10.35614/isbn.9789523361461 
Julkaisija: Ilmatieteen laitos

(Erik Palménin aukio 1)

PL 503, 00101 Helsinki

Tekijä

Mika Vestenius

Nimeke

Valittujen orgaanisten yhdisteiden lähteitä ilmankehän aerosoleissa Suomessa

\section{Tiivistelmä}

Ilmansaasteet ovat merkittävä riski luonnolle ja inmisten terveydelle. Hiukkaset, erityisesti pienhiukkaset, ovat merkittävä osa ilmansaasteongelmaa. Ilmakehän hiukkasten koostumus vaihtelee suuresti päästölähteen mukaan. IImakehässä oleva hiukkanen voi sisältää epäorgaanisten yhdisteiden lisäksi useita satoja orgaanisia yhdisteitä, jotka voivat olla peräisin luonnollisista tai inmisperäisistä lähteistä. Hiukkasten aiheuttama terveysriski muodostuu hiukkasten koosta ja niiden sisältämistä myrkyllisistä yhdisteistä.

Tämän väitöskirjan tarkoituksena oli tutkia valittuja ilmakehän aerosolissa olevia, luonnosta ja ihmisen toiminnasta peräisin olevia kemiallisten yhdisteiden pitoisuuksia ja niiden lähteitä. Työssä selvitettiin polysyklisten aromaattisten hilivetyjen (PAH yhdisteiden) ja biogeenisten orgaanisten happojen pitoisuuksia ilmakehän aerosolissa ja niiden vaikutusta paikalliseen ilmanlaatuun. PAH-yhdisteiden, hivenaineiden ja biogeenisten orgaanisten yhdisteiden lähteitä ilmassa tutkittiin positiivisen matriisin faktorisointi -menetelmällä kolmessa tähän työhön liittyvässä artikkelissa. Myös ennen julkaisemattomia tuloksia pysyvien orgaanisten yhdisteiden (POP) lähteistä Arktisella alueella esitetään tässä työssä.

Polttoperäiset, erityisesti dieselin ja biomassan palamisesta peräisin olevat hiukkaset ovat tyypillisesti myrkyllisimpiä hiukkasia elinympäristössämme. Kotitalouksien puunpoltto lämmityksessä ja mm. saunan lämmityksen yhteydessä on PAH-yhdisteiden päälähde Suomessa. PAH-yhdisteiden lähteitä ja niiden vaikutusta paikalliseen ilmanlaatuun arvioitiin Virolahdella ja pääkaupunkiseudulla. Selvisi että päälähde Virolahden PAH-pitoisuuksiin hengitettävissä hiukkasissa $\left(\mathrm{PM}_{10}\right)$ liittyy Pietarin polttoperäisiin ja liikenteen päästöihin. Kuitenkin Helsingin seudulla puun pienpoltto osoittautui merkittävimmäksi b(a)p -lähteeksi. Pääkaupunkiseudun liikenteen osuus b(a)p pitoisuuksiin on pieni.

Biogeenisistä haihtuvista orgaanisista yhdisteistä (BVOC-yhdisteistä) esimerkiksi mono- ja seskviterpeenit ovat hyvin reaktiivisia ja tuottavat sekundäärisia orgaanisia aerosolihiukkasia. Tässä työssä osoitettiin, että PMF-reseptorimallinnusta voidaan käyttää myös ilmakehässä nopeasti muuntuvien yhdisteiden lähteiden arviointiin boreaalisessa metsässä. Biogeenisten orgaanisten happojen, jotka ovat terpeenien hapetustuotteita, pitoisuuksia mitattiin hiukkasista boreaalisessa metsässä, jotta voitaisiin arvioida näiden vaikutusta aerosolin muodostukseen. Työssä todettiin, että seskviterpeenien osuutta aerosolin muodostukseen on aikaisemmin todennäköisesti aliarvioitu.

Kuolan niemimaalla oleva metalliteollisuus osoittautui raskasmetallien päälähteeksi Pallaksen alueella. Norilsk Nickel on kuitenkin osittain sulkemassa metallurgisia toimintojaan Suomen lähialueilla, joten sen aiheuttamat rikkidioksidi- ja raskasmetallipäästöt tulevat todennäköisesti pienenemään lähitulevaisuudessa.

POP-yhdisteiden pitoisuudet ilmakehässä ovat pienentyneet yleisesti kaikkialla maailmassa, mutta joidenkin yhdisteiden kohdalla näin ei ole tapahtunut Arktisella alueella. Tässä työssä julkaistun reseptorimallinnusanalyysin mukaan merkittävä osa Pallaksella mitatuista POP-yhdisteistä tulee pohjoisten ilmavirtausten mukana puhtailta alueilta, joilla ei ole näiden yhdisteiden merkittäviä ensisijaisia lähteitä. Nämä pitkäikäiset yhdisteet, jotka ovat kertyneet vuosikymmenien ajan Arktiselle alueelle ilman- ja merivirtausten mukana, ovat ilmaston lämpenemisen myötä ja Arktisen jääpeitteen sulamisen myötä nyt vapautumassa uudelleen ilmakehään. Arktinen alue on näiden yhdisteiden osalta muuttunut nielusta lähteeksi.

\section{Julkaisijayksikkö}

IImatieteen laitos, IImakehän koostumuksen tutkimus

\section{Luokitus (UDK) \\ 502.3:613.15; 543.275;}

$661.715 ; 551.510 .4 ; 614.71$

DOI: https://doi.org/10.35614/isbn.9789523361461

\author{
Asiasanat \\ IImakehä, IImanlaatu, ilmansaasteet, ilmakehän aerosolit, \\ orgaaninen aerosoli, aerosolin kemiallinen koostumus, hiilivedyt, \\ polysykliset aromaattiset hiilivedyt, pysyvät orgaaniset yhdisteet, \\ ilmakehän mittaukset, reseptorimallitus \\ ISBN 978-952-336-146-1 (pdf) \\ ISBN 978-952-336-147-8 (paperback)
}




\section{Acknowledgements}

The research of this thesis was carried out at the Air Quality group in the Atmospheric Composition Research unit of the Finnish Meteorological Institute.

For the opportunity to work at FMI, I express my gratitude to the former and current unit leaders, Professor Jaakko Kukkonen, Docent Heikki Lihavainen, as well as Professor Hannele Hakola who has also acted as my thesis supervisor and group leader in earlier years. Hannele, special thanks for hiring me, believing in me and this thesis, especially in the final stage, giving the push to do it. I am deeply grateful to my previous group leader Docent Heidi Hellén for the support over the years. I also wish to thank my current unit leader Harri Pietarila and group leader Katja Lovén, for the opportunity to write this work also during work time. Professor Marja-Liisa Riekkola at the Department of Chemistry at Helsinki University is kindly thanked for getting me interested in analytical chemistry as a Master student, introducing me to FMI, and finally for supporting me through my postgraduate studies.

My sincere thanks to Associate Professor Topi Rönkkö (Tampere University) and Docent Jorma Joutsensaari (University of Eastern Finland), for reviewing and commenting this thesis. I highly appreciate that Associate Professor Marianne Glasius from the Aarhus University has kindly promised to be my opponent in the public examination of this thesis.

I would like to acknowledge all my co-authors for discussions, input, and improvements to my work. These articles and this thesis would not exist without your help. I want to thank all my colleagues, for co-operation and support during the various phases in my work career, and for many fruitful discussions. Special thanks to Ulla and Katja for believing in me and giving support in the last writing phase. Katriina, Karri, Anne-Mari, Anne, Janne, Simon, Arno, Minna, Philip, Helena, Matias and many other colleagues inside and outside FMI, thanks for creating the pleasant and inspiring atmosphere at work. Sometimes work might feel overwhelming, but usually it is easier to fix things together, whether they are issues with an instrument or with data, etc. Thanks to all of you for the enjoyable moments in the lab, in the field and outside the office, especially at coffee and lunch breaks.

Music and playing in the band have been essential in my life outside FMI. Thanks Hautis and my other muso colleagues in Discover the Band, and in the other bands, for bringing lots of joy and happiness into my life.

Finally, my warmest gratitude is expressed to my family. Thank You Mom, and Dad, for always believing in me and for your endless support. Thanks Sis, for your support and many laughs and good questions like, what is the point of this work ;-) My family, my dear wife Sarri, your love, support and flexibility during the years has been outstanding. Thank You for that. You Sarri, and my precious children, Sakari, Iris, and Syksy, are the best and the most important things in my life.

Helsinki, October 2021

Mika Vestenius 


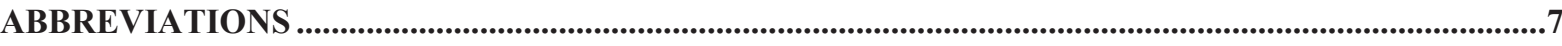

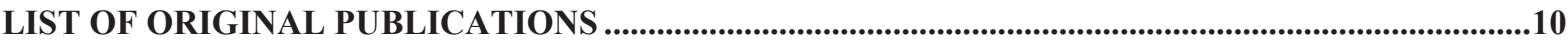

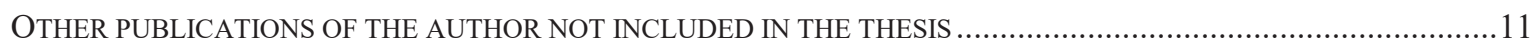

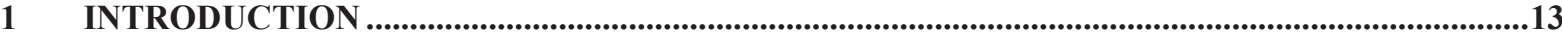

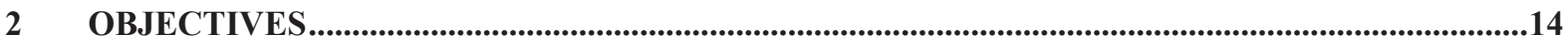

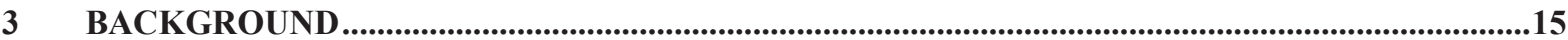

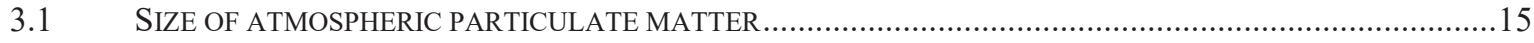

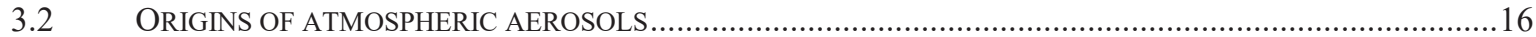

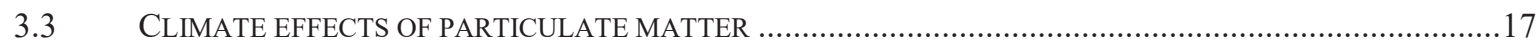

3.4 CHEMICAL COMPOSITION OF PARTICULATE MATTER .............................................................. 17

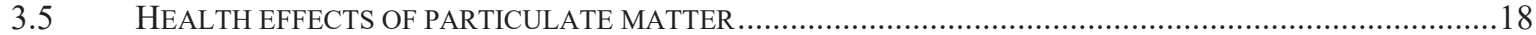

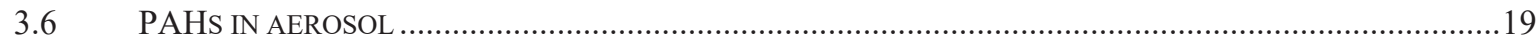

P.7 PERSISTENT ORGANIC COMPOUNDS IN THE ENVIRONMENT …....................................................23

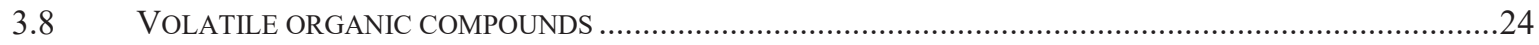

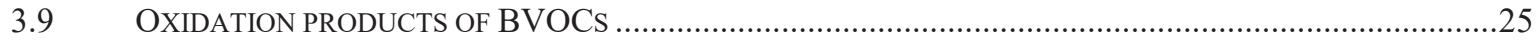

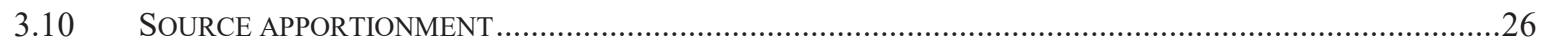

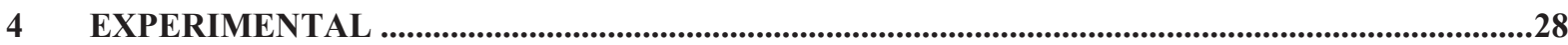

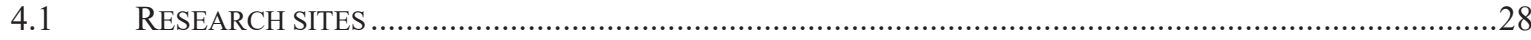

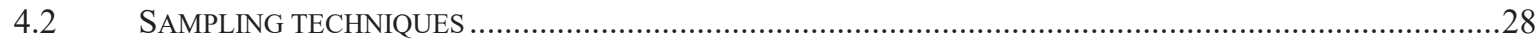

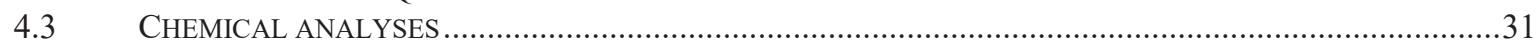

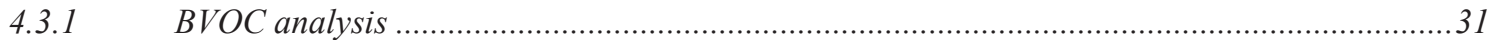

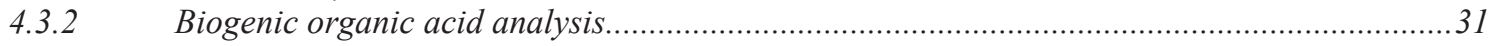

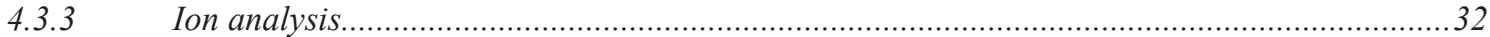

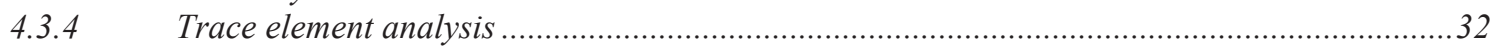

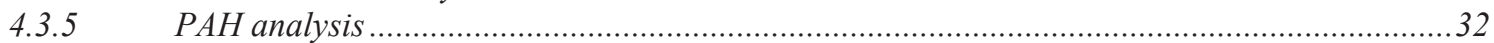

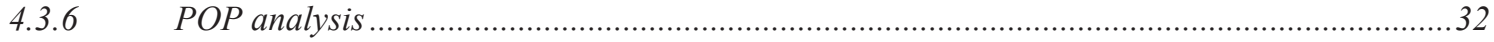

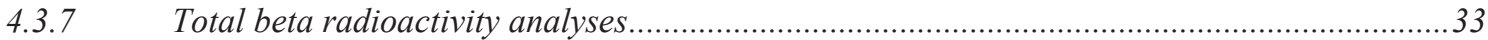

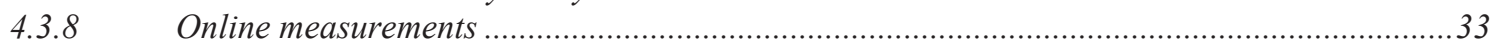

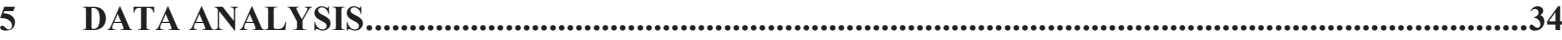

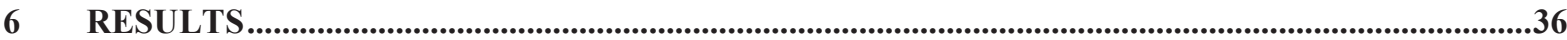

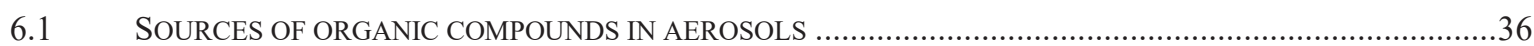

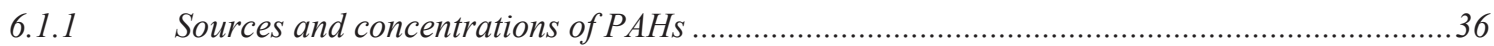

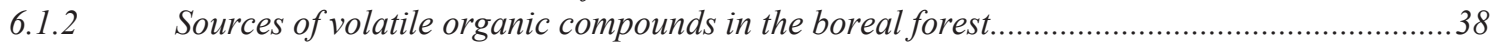

6.1.3 Biogenic acids in aerosol in the boreal forest ................................................................41

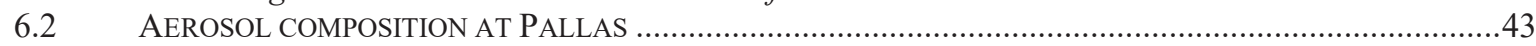

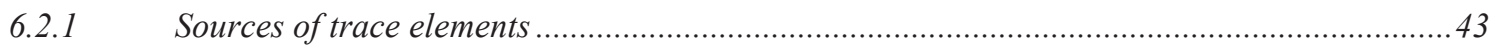

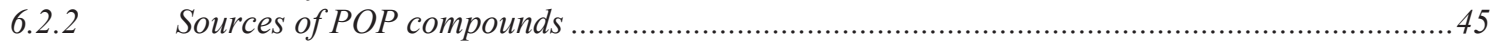

7 REVIEW OF PAPERS AND AUTHOR'S CONTRIBUTION ............................................................51

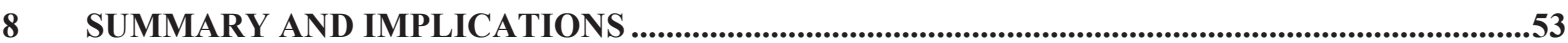

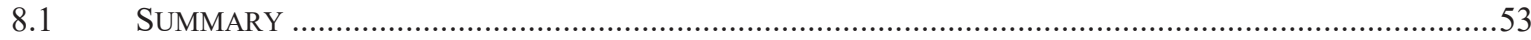

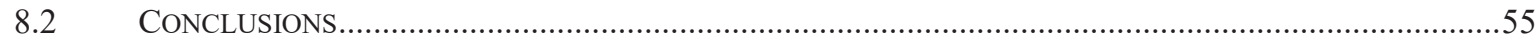

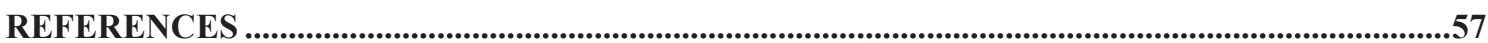




\section{ABBREVIATIONS}

$\left(\mathrm{NH}_{3} \_\mathrm{NH} 4\right) \mathrm{N}$ sum of ammonia and ammonium, calculated as nitrogen

4-ACMH 4-acetyl-methylcyclohexanone

AMAP Arctic Monitoring Assessment Program

As Arsenic

b(a)p Benzo(a)pyrene

BVOC Biogenic organic compound

$\mathrm{Ca} \quad$ Calcium

CBPF Conditional bivariate probability function

$\mathrm{Cd} \quad$ Cadmium

CEN European Committee for Standardization

CFC Chlorofluorocarbon/-s

$\mathrm{Cl} \quad$ Chlorine

CLRTAP Convention on Long-range Transboundary Air Pollution

CMB Chemical mass balance

Co Cobalt

CO Carbon monoxide

$\mathrm{Cr} \quad$ Chromium

CRM Certified reference material

$\mathrm{Cu} \quad$ Copper

DCM Dichloromethane

DDD Dichlorodiphenyldichloroethane

DDE Dichlorodiphenyldichloroethylene

DDT Dichlorophenyltrichloroethane

EC Elemental carbon

EC European Commission

EMEP European Monitoring and Evaluation Programme

EPA Environmental protection Agency, USEPA

ETC/ACM European Topic Centre on Air Pollution and Climate Change Mitigation

EU European Union

$\mathrm{Fe} \quad$ Iron

FMI Finnish Meteorological Institute

GC-MS Gas chromatograph-mass spectrometer

GC/ECD Gas chromatograph equipped with electron capture detector

GDP Gross domestic product

HCB Hexachlorobenzene

HM Heavy Metal/-s

HMA Helsinki Metropolitan Area

HPLC-ESI-ITMS High-performance liquid chromatograph - ion trap mass spectrometer equipped with electrospray injector

HPLC/FLD High-performance liquid chromatograph equipped with fluorescence detector

IC Ion chromatograph/chromatography

ICP-MS Inductively coupled plasma mass spectrometer/spectrometry

IVL Svenska Miljöinstitutet, Swedish Environmental Research Institute

K Potassium

LRT Long-range transport

MACR Methacrolein 


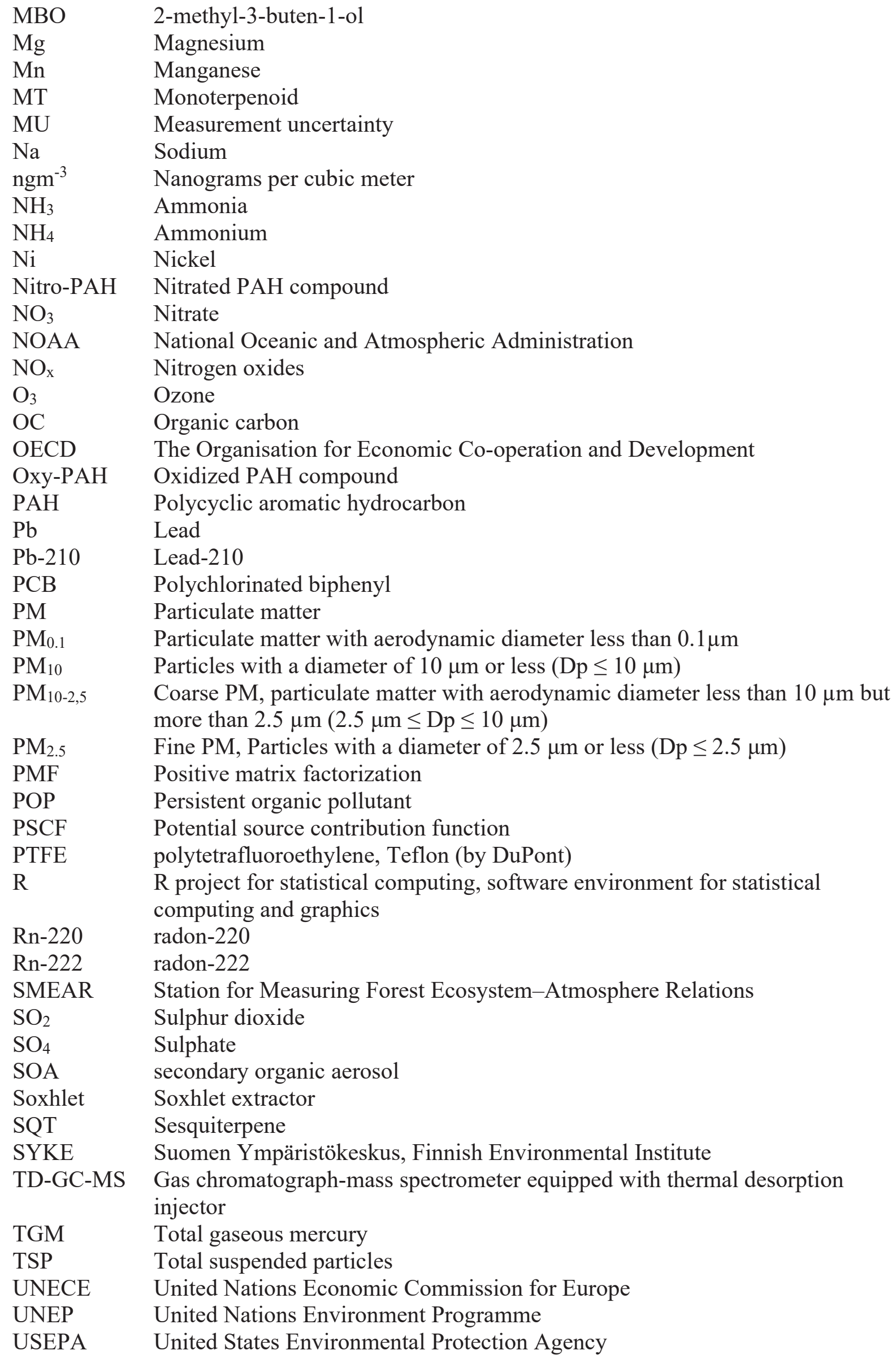




$\begin{array}{ll}\text { UV } & \text { ultraviolet } \\ \text { V } & \text { Vanadium } \\ \text { VOC } & \text { volatile organic compound } \\ \text { WHO } & \text { World Health Organization } \\ \text { WMO } & \text { World Meteorological Organization } \\ \text { Zn } & \text { Zinc } \\ \alpha \text {-chlordan } & \text { alpha-chlordan } \\ \alpha-H C H & \text { alpha-hexachlorocyclohexane } \\ \gamma \text {-chlordan } & \text { gamma-chlordan } \\ \gamma-\mathrm{HCH} & \text { gamma-hexachlorocyclohexane } \\ \mu \mathrm{gm}{ }^{-3} & \text { micrograms per cubic meter } \\ \mu \mathrm{m} & \text { micrometer, } 10^{-6} \mathrm{~m}\end{array}$




\section{LIST OF ORIGINAL PUBLICATIONS}

This thesis consists of an introductory review followed by five original research articles. In addition, unpublished results about the sources of persistent organic pollutants at Pallas are included. The research articles are reproduced with the kind permission of the journals concerned. References to the articles are indicated in the text by their Roman numerals.

I Vestenius M., Hopke P.K., Lehtipalo K., Petäjä T., Hakola H., Hellén H., Assessing volatile organic compounds sources in a boreal forest using positive matrix factorization (PMF). Atmospheric Environment 259 (2021), 118503, ISSN 13522310, doi:10.1016/j.atmosenv.2021.118503.

II Kyllönen K., Vestenius M., Anttila P., Makkonen U., Aurela M., Wängberg I., Nerentorp Mastromonaco M., Hakola H. Trends and source apportionment of atmospheric heavy metals at a subarctic site during 1996-2018. Atmospheric Environment 236 (2020), 117644, doi:10.1016/j.atmosenv.2020.117644.

III Hellén H., Kangas L., Kousa A., Vestenius M., Teinilä K., Karppinen A., Kukkonen J., Niemi J.V. Evaluation of the impact of wood combustion on benzo[a]pyrene (b(a)p) concentrations; ambient measurements and dispersion modeling in Helsinki, Finland. Atmospheric Chemistry and Physics 17 (2017), 3475-3487, doi:10.5194/acp-17-34752017.

IV Vestenius M., Hellén H., Levula J., Kuronen P., Helminen K.J., Nieminen T., Kulmala M., Hakola H. Acidic reaction products of monoterpenes and sesquiterpenes in atmospheric fine particles in a boreal forest. Atmospheric Chemistry and Physics 14 (2014), 7883-7893, doi: 10.5194/acp-14-7883-2014.

V Vestenius M., Leppänen S., Anttila P., Kyllönen K., Hatakka J., Hellén H., Hyvärinen A., Hakola H. Background concentrations and source apportionment of polycyclic aromatic hydrocarbons in south-eastern Finland. Atmospheric Environment 20 (2011), 45, 3391-3399, doi:10.1016/j.atmosenv.2011.03.050.

Unpublished data: Vestenius M., Sources of persistent organic pollutants (POPs) at sub-Arctic site during 1996-2018. (Addition to the data presented in Paper II) 
Other publications of the author not included in the thesis

Belis C., Pernigotti D., Pirovano O., Favez O., Jaffrezo J-L., Kuenen J., Denier van der Gon H., Reizer M., Riffault V., Alleman L., Almeida M., Amato F., Angyal A., Argyropoulos G., Bande S., Beslic I., Besombes J-L., Chiara Bove M., Brotto P., Calori G., Cesari D., Colombi C., Contini D., De Gennaro G., Di Gilio A., Diapouli E., El Haddad I., Elbern H., Eleftheriadis K., Ferreira J., Garcia Vivanco M., Gilardoni S., Golly B., Hellebust S., Hopke P., Izadmanesh Y., Jorquera H., Krajsek K., Kranenburg R., Lazzeri P., Lenartz F., Lucarelli F., Maciejewska K., Manders A., Manousakas M-I., Masiol M., Mircea M., Mooibroek D., Nava S., Oliveira D., Paglione M., Pandolfi M., Perrone M.G., Petralia E., Pietrodangelo A., Pillon S., Pokorna P., Prati P., Salameh D., Samara C., Samek L., Saraga D., Sauvage S., Schaap M., Scotto F., Sega K., Siour G., Tauler R., Valli G., Vecchi R., Venturini E., Vestenius M., Waked A., Yubero E., Evaluation of receptor and chemical transport models for PM10 source apportionment. Atmospheric Environment X, Vol. 5 (2020), 100053, ISSN 2590-1621, https://doi.org/10.1016/j.aeaoa.2019.100053.

Jaars K., Vestenius M., Zyl P.G., Beukes J.P., Hellén H., Vakkari V., Venter M., Josipovic M., Hakola H. Receptor modelling and risk assessment of volatile organic compounds measured at a regional background site in South Africa. Atmospheric Environment Vol. 172 (2018), 133148. https://www.sciencedirect.com/science/article/pii/S1352231017307124, doi: 10.1016/j.atmosenv.2017.10.047.

Anttila P., Brorström-Lundén E., Hansson K., Hakola H., Vestenius M. Assessment of the spatial and temporal distribution of persistent organic pollutants (POPs) in the Nordic atmosphere. Atmospheric Environment 140 (2016), 22-33.

Joensuu J., Altimir N., Hakola H., Rostas M., Raivonen M., Vestenius M., Aaltonen H., Riederer M., Bäck J. Role of needle surface waxes in dynamic exchange of mono- and sesquiterpenes. Atmospheric Chemistry and Physics 16 (2016), 7813-7823.

Belis C., Karagulian F., Amato F., Almeida M., Artaxo P., Beddows D.C.S., Bernardoni V., Bove M.C., Carbone S., Cesari D., Contini D., Cuccia E., Diapouli E., Eleftheriadis K., Favez O., El Haddad I., Harrison R.M., Hellebust S., Hovorka J., Jang E., Jorquera H., Kammermeier T., Karl M., Lucarelli F., Mooibroek D., Nava S., Nojgaard J.K., Paatero P., Pandolfi M., Perrone M.G., Petit J.E., Pietrodangelo A., Pokorna P., Prati P., Prevot A.S.H., Quass U., Querol X., Saraga D., Sciare J., Sfetsos A., Valli G., Vecchi R., Vestenius M., Yubero E., Hopke P.K. A new methodology to assess the performance and uncertainty of source apportionment models II: The results of two European intercomparison exercises. Atmospheric Environment 123 (2015), 240-250.

Hooda R., Hyvärinen A., Vestenius M., Gilardoni S., Sharma V.P., Vignati E., Kulmala M., Lihavainen H. Atmospheric aerosols local-regional discrimination for a semi-urban area in India. Atmospheric Research 168 (2015), 13-23, doi: 10.1016/j.atmosres.2015.08.014.

Saarnio K., Frey A., Niemi J.V., Timonen H., Rönkkö T., Karjalainen P., Vestenius M., Teinilä 
K., Pirjola L., Niemelä V., Keskinen J., Häyrinen A., Hillamo R. Chemical composition and size of particles in emissions of a coal-fired power plant with flue gas desulfurization. Journal of Aerosol Science 73 (2014), 14-26, doi:10.1016/j.jaerosci.2014.03.004.

Häkkinen S.A.K., Äijälä M., Lehtipalo K., Junninen H., Backman J., Virkkula A., Nieminen T., Vestenius M., Hakola H., Ehn M., Worsnop D.R., Kulmala M., Petäjä T., Riipinen I. Longterm volatility measurements of submicron atmospheric aerosol in Hyytiälä, Finland. Atmospheric Chemistry and Physics 12 (22) (2012), 10771-10786.

Haapanala S., Hakola H., Hellén H., Vestenius M., Levula J., Rinne J. Is forest management a significant source of monoterpenes into the boreal atmosphere? Biogeosciences 9 (2012), 1291-1300.

Paatero J., Vaattovaara P., Vestenius M., Meinander O., Makkonen U., Kivi R., Hyvärinen A., Asmi E., Tjenström M., Leck K. Finnish Contribution to the Arctic Summer Cloud Ocean Study (ASCOS) Expedition, Arctic Ocean 2008. Geophysica 45 (1-2) (2009), 119-146.

Kuronen M., Harjula R., Jernström J., Vestenius M., Lehto J. Effect of the framework charge density on zeolite ion exchange selectivities. Physical Chemistry Chemical Physics 2 (11) (2000), 2655-2659. 


\section{INTRODUCTION}

Air pollution was recognized as a health problem centuries ago. Burning was and still is a common way to produce energy and get rid of unwanted waste - as long it burns. Urbanization, the growing population with all its side effects, has brought many kinds of environmental problems even centuries ago, and the order of magnitude of environmental pollution has expanded greatly along with global industrialization.

Air pollution is a global phenomenon. It is an important environmental risk to human health and ecosystems around the world. Related health issues like respiratory and cardiovascular diseases, asthma, and allergies are serious problems for humans. Related ecosystem problems include, e.g., eutrophication and, nowadays to a lesser extent, acidification. It has been estimated that four million lives are lost annually due to ambient air pollution exposure (EC 2021, WHO 2006). In addition to health and ecosystem burdens, air pollution also has a large effect on economics. The OECD has recently estimated that a $1 \mu \mathrm{g} / \mathrm{m}^{3}$ decrease in annual mean ambient $\mathrm{PM}_{2.5}$ concentration would increase Europe's gross domestic product (GDP) by $0.8 \%$ (OECD 2019). The environmental burden and danger to human health and ecosystems caused by air pollution has been largely recognized, and limit and target values as well as guidance values have been set by, e.g., the European Union (EU), United States Environmental Protection Agency (USEPA), and World Health Organization (WHO).

However, as the air pollution situation has been improved greatly in Western countries, emissions and concentrations have increased in many areas worldwide. Also in Europe, air quality guidelines are still commonly exceeded, and air quality remains poor in many areas despite reductions in emissions and ambient concentrations. In developing countries, the situation is still far worse in many cases.

There have also been success stories; annual average ambient $\mathrm{SO}_{2}$ levels have decreased over $70 \%$ in Europe in the last two decades due to decreased emissions (ETC/ACM 2020). Successful restrictions on emissions of chlorofluorocarbons (CFCs) have successfully managed to decrease the amount of chlorinated and fluorinated hydrocarbons that work as catalysts in ozone depletion in the upper atmosphere. International restrictions of the use and production of persistent organic pollutants (POPs) have decreased their concentrations in the environment, and the concentrations show a decreasing trend for many POPs (e.g., Anttila et al. 2016). However, for burning originated polycyclic aromatic hydrocarbons (PAHs), there is no declining trend for the ambient concentrations of these compounds due to continuous emissions (EMEP 2020).

When looking for the most effective way to improve local air quality, the best solution is not always clear. It can be difficult to assess the most effective and reasonable measures to achieve the best improvement of local air quality. Defining the main local emission sources of pollutants in different kinds of environments can be challenging. There are many kinds of potential sources like traffic, different kinds of industrial and construction activities, local biomass 
burning in cooking and residential activities, power plants, and long-range transported pollution, etc. Source apportionment can be a useful tool for assigning dominant pollution sources. Using the source apportionment tool with measurement campaign results can give useful information to decision makers regarding what kinds of actions would be most effective.

Global warming also creates new problems. Air pollution that has accumulated into arctic ice for decades in the northern latitudes is now being released back into the atmosphere due to the warming climate. Certain persisted organic compounds, e.g., polychlorinated biphenyls (PCB compounds) were used for decades before their cumulative danger to the ecosystem due to their toxicity and low degradation rate was realized. This type of pollution has been spread all over the globe, eventually accumulating into previously clean arctic areas via air and sea currents from the southern latitudes. The ambient concentrations of these compounds are globally declining due to restrictions on production and use of these compounds, but some compounds' concentrations in the Arctic are not declining. It has been estimated that, due to the warming climate, some of these compounds are now released back into the atmosphere from arctic waters and ice (e.g., Wöhrnschimmel et al. 2012, Bidleman et al. 2015, Wong 2021).

\section{OBJECTIVES}

The overall aim of this thesis was to study selected chemical substances of atmospheric aerosol from both anthropogenic and natural sources. Concentrations of polycyclic aromatic hydrocarbons and biogenic organic acids in aerosol were measured, and their effect on the local air quality was estimated. Sources of PAHs, trace elements, biogenic volatile organic compounds, and persistent organic compounds were studied using positive matrix factorization (PMF), which was used as the main source apportionment tool in three of five papers and for the unpublished data in this thesis.

The specific objectives of this thesis were to study:

- the levels of polycyclic aromatic hydrocarbons in ambient air at the background site and determine their main sources (Paper V) and to study the influence of wood burning on PAH levels in the Helsinki Metropolitan Area (HMA) (Paper III)

- the variation of the concentrations of biogenic organic acids measured in the fine particles in the boreal forest (Paper IV)

- sources of biogenic organic compounds (BVOCs) in the boreal forest (Paper I); these compounds are, e.g., precursors of the organic acids measured in Paper IV

- whether PMF can be used for the source apportionment of reactive BVOC systems in the boreal forest (Paper I)

- the sources of trace elements (Paper II) and persistent organic pollutants (unpublished results) at Pallas using PMF and trajectory analysis methods. 


\section{BACKGROUND}

Poor air quality is caused by air pollutants, which can be of anthropogenic or natural origin (Figure 1). Air pollutants emitted straight from the source to the atmosphere are called primary air pollutants. These include sulfur dioxide, nitrogen oxides, carbonaceous and noncarbonaceous particles, carbon monoxide, and volatile organic compounds (VOCs). Secondary air pollutants are formed in the atmosphere from precursor gases either from anthropogenic or natural origin. These are, for example, sulfate- and nitrate-containing compounds, secondary organic particulate matter, ozone, and nitrogen dioxide (WHO 2006).
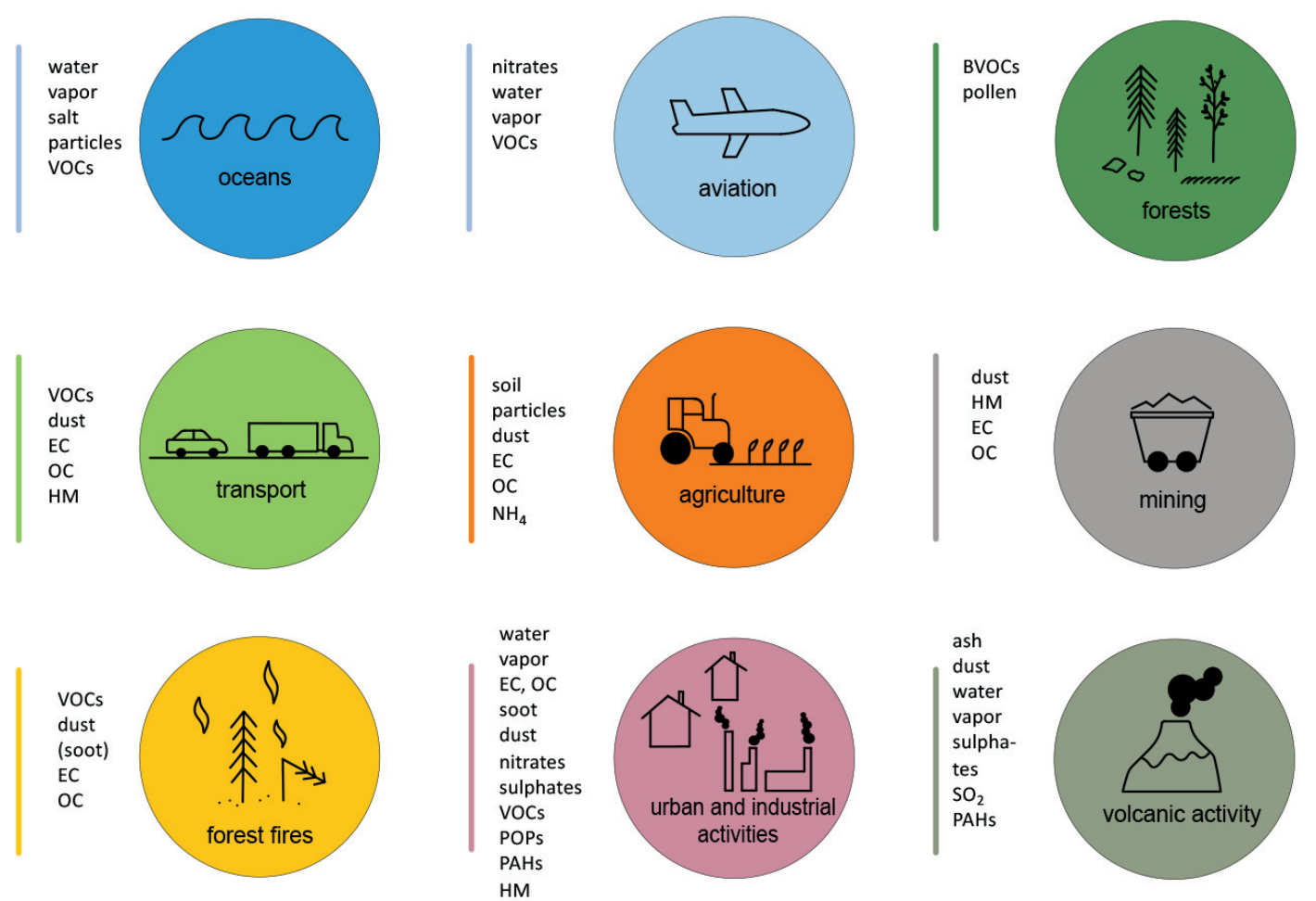

Figure 1. Some major air pollution and aerosol sources. Water vapor and sea salt are not air pollution as such, but they take part to particle formation and growth (e.g., Rosenfeld et al., 2002). Illustration by Syksy Vestenius. Used with permission.

\subsection{Size of atmospheric particulate matter}

Particle size is an important characteristic of particulate matter. It affects particle transport in the atmosphere and influences the climate effects, visibility, and health effects of PM. Particles are classified according to their size. $\mathrm{PM}_{10}$ (particulate matter with an aerodynamic diameter less than $10 \mu \mathrm{m}$ ) can penetrate the lungs and stay there, causing cardiovascular symptoms; therefore, this size class is called inhalable particles. $\mathrm{PM}_{2.5}$ (particles with an aerodynamic diameter less than $2.5 \mu \mathrm{m}$ ) can penetrate farther into the lungs (alveoli), and $\mathrm{PM}_{0.1}$ (particles with an aerodynamic diameter less than $0.1 \mu \mathrm{m}$ ) can enter the blood. $\mathrm{PM}_{2.5}$ is also called fine 
particles or fine particulate matter. This work focuses on $\mathrm{PM}_{10}$ and $\mathrm{PM}_{2.5}$, and also on volatile organic compounds (VOCs), which can act as precursors of particles (e.g., Shrivastava et al. 2017).

\subsection{Origins of atmospheric aerosols}

Natural aerosol sources include windblown soil, natural weathering of crustal rock, burning emissions from volcanic activities and forest fires, sea spray and biogenic originated secondary aerosol formation, where primary volatile organic compounds emitted from vegetation react in the atmosphere and form aerosol (Kulkarni et al, 2011).

Anthropogenic particulate matter sources can be roughly categorized as four main sources: fuel combustion for energy production, industrial processes, nonindustrial fugitive sources (roadway dust, winter sanding, etc., wind erosion, constructions, and other land use) and transportation sources (Seinfeld and Pandis 1998). Fugitive aerosol sources are not able to point out a definable point such as a stack. Industrial processes often contain burning of fuels and heating of materials such as smelters, which cause burning and other kinds of emissions, such as soot and heavy metal-containing aerosol emissions. Transportation sources consist of trafficrelated particles from vehicle exhaust and particles from tires, clutch, and brakes wear. Road traffic emissions greatly contribute to PM concentrations and to human exposure of PM, especially in urban areas (Pant and Harrison 2013). Fine PM from fuel burning, especially diesel soot, is the most dangerous type of PM in relation to health issues (Park et al. 2018).

Residential wood burning also has a significant effect on $\mathrm{PM}_{2.5}$ pollution. Kukkonen et al. (2020) studied the influence of residential wood burning on $\mathrm{PM}_{2.5}$ concentrations in four Nordic cities (Helsinki, Oslo, Umeå, and Copenhagen); they found that the effect on $\mathrm{PM}_{2.5}$ concentration in these cities varied from $0 \%$ to $20 \%$ in Helsinki and up to $60 \%$ in Oslo. In Helsinki, elevated $\mathrm{PM}_{2.5}$ concentrations typically existed in detached one-family house areas outside the city center, where wood is used as a supplementary heating source and in sauna stoves. Elevated concentrations were also found near major roads. In Oslo, the highest concentrations were measured in the eastern part of the city, but residential wood burning had a significant effect on $\mathrm{PM}_{2.5}$ concentrations also in central Oslo area.

Coarse particles $\left(D_{\mathrm{p}} 2.5-10 \mu \mathrm{m}\right)$ have an aerodynamic diameter greater than $2.5 \mu \mathrm{m}$ but smaller than $10 \mu \mathrm{m}$. Coarse particles are formed by mechanical processes; they usually consist of natural dust particles and anthropogenic particles, which typically include mineral-containing soil particles, sea salt particles, resuspended road dust, and biological particles like pollen (Kulkarni et al.,2011). Coarse particles are removed from the atmosphere by, e.g., precipitation, and their residence time in the atmosphere is short, from a few hours to one day.

Fine particles $\left(D_{p}<2.5 \mu\right.$ m), i.e., $P_{2.5}$, can stay in the atmosphere much longer. Fine particles can also originate from natural and anthropogenic sources. Important sources of fine mode 
particles include burning emissions, e.g., combustion of fossil fuels and biomass burning, as well as gas-to-particle conversion. Oxidation products of volatile organic compounds, measured in Paper IV, exist and grow in fine mode. Also, most PAH compounds typically exist in fine mode, although they are measured in $\mathrm{PM}_{10}$ fraction. Fine particles can travel with air masses for thousands of kilometers; long-range transport is an important source of fine particles in remote areas (e.g., Laakso et al. 2003, Makkonen 2014, Kulkarni et al. 2011, Seinfeld and Pandis, 1998).

\subsection{Climate effects of particulate matter}

Particulate matter has direct and indirect climate effects. Aerosol particles in the atmosphere scatter incoming radiation back to space, and some of them absorb solar radiation. This is called the direct aerosol effect, and it has a negative climate forcing effect (Haywood and Boucher, 2000). However, light absorbing particles such as black carbon effectively absorb solar radiation and warm the surrounding atmosphere, melt snow and ice and have effect on eath's albedo, thus BC has positive climate forcing effect (Bond et al. 2013; Qian et al. 2015).

Some aerosols act as cloud condensation nuclei, thus affecting cloud albedo and its lifetime; that is called indirect effect. One example of particles that may form cloud condensation nuclei is biogenic organic compounds emitted from plants, that oxidize in the air and may produce particles via condensation on the existing particles, or they can create new aerosol particles through gas-to-particle conversion. This happens, e.g., in boreal forests, where biogenic organic compounds emitted from plants are oxidized and produce aerosol, when the ambient conditions are favorable. If particles grow big enough, they can form activated cloud droplets (Kulmala et al. 1999). As approximately one-third of the northern hemisphere is covered by boreal forests, their effect on the global climate is probably significant (e.g., Tunved et al. 2006, Papers I and IV).

\subsection{Chemical composition of particulate matter}

Aerosols contain various chemical compounds, many of which are harmful to the environment or human health. The danger of PM is related to the kinds of toxic compounds it includes, so in addition to particle size, the chemical composition of PM is directly related to health effects.

The chemical composition of PM depends strongly on its source. Atmospheric particles, in general, consist of sulphates, nitrates, ammonium, elemental carbon (EC), organic carbon (OC), crustal species, heavy metals, sea salt, and water. EC, OC, ammonium, sulphate, and some metals are generally found in fine particles, whereas crustal materials like silicon, calcium, magnesium, aluminum, and iron and biogenic particles such as pollen and spores are usually in coarse fraction (Saarnio 2013). 
Organic carbonaceous aerosol (OC) is typically the largest fraction in the fine particles in European urban background areas (e.g., Seinfeld 2002, Sillanpää et al. 2006, Crippa et al. 2013, Aurela 2016). OC can be emitted directly from sources as primary organic aerosol or be formed in the atmosphere as secondary organic aerosol, SOA. SOA is formed in the atmosphere by nucleation or condensation on existing particles (e.g., Jimenez et al. 2009). Sillanpää et al. (2005) and Crippa (2013) showed that combustion emissions from vehicles and other fossil fuel, such as oil and coal burning, as well as biomass burning mainly impacted on OC concentration in urban background areas in Europe. Glasius et al. (2018) studied the organic aerosol composition in six background areas in Northern Europe and showed that during wintertime, biomass burning, especially wood burning for residential heating, has had a major impact $(>40 \%)$ on the carbonaceous aerosol (OC and elemental carbon EC) concentration in Northern Europe.

Organic particulate fraction can contain several hundred organic compounds, including semiand low-volatile organic compounds, e.g., PAH compounds, and sugar anhydrides (e.g., levoglucosan) that may be from anthropogenic combustion, or natural burning sources (e.g., wildfires and volcanic activity).

In addition, organic fraction includes terpenoids and sesquiterpenoids that are emitted from biogenic sources, and their oxidation products, that are formed in the atmosphere (e.g., Johnson et al. 2006). In this work, we concentrate on biogenic organic compounds, PAHs and POPs, and also on atmospheric trace elements. Even though these compounds make up only a small portion of fine particle mass, they have an important effect on the local air quality.

\subsection{Health effects of particulate matter}

Particulate matter has been found to cause important environmental risk to human health (e.g., Hänninen et al. 2014), especially in those with cardiovascular diseases (Pope and Dockery 2006, WHO 2006, EC 2021, and others).

The European Union has noted a need to reduce several air pollutants. To protect human health and the environment and to minimize harmful effects, the EU has set several limit and target values for air pollutants (EU 2008).

The toxicity of the compounds inside the particle or on the surface of the aerosol particles plays an important role in the toxicity of atmospheric PM. Park et al. (2018) studied fine PM emitted from different sources and found that fine particles are not equally toxic; the toxicity varies even at similar $\mathrm{PM}_{2.5}$ concentrations and depends heavily on the source of the aerosol and on the particles' chemical composition. They found that particles from burning emissions, e.g., diesel and biomass burning particles, were most toxic among the studied compounds. These toxic burning particles commonly contain a lot of organic material, e.g., PAHs, which were studied in Papers III and V in this thesis. Fossil fuel burning traces, especially from coal burning 
and diesel smoke in fine particles, were found to be significantly associated with ischemic heart disease mortality in the U.S. during 1982-2004 (Thurston et al. 2016). Sarigiannis et al. (2015) measured PAHs in $\mathrm{PM}_{10}$ and $\mathrm{PM}_{2.5}$ in urban background and urban traffic environments; they found that biomass burning particles are more toxic than PMs originating in traffic in terms of PAH content per mass. Larger, higher molecular weight PAH compounds are found to be more toxic, and these heavier PAHs tend to partition to particles more easily compared to the lighter ones (Mesquita et al. 2014). Also, burning at low temperatures, such as residential biomass burning, was found to produce more toxic organic compounds when compared to, e.g., coal burning at higher temperatures in power plants (Park et al. 2018).

Many trace elements studied in Paper II are also toxic to humans even in small amounts; for example, arsenic, cadmium, nickel, and lead are carcinogens, and limit and target values have been set to restrict concentrations of those trace elements in the air (e.g., EU 2004, 2008). These elements also occur naturally in the environment but are mainly released into the atmosphere by anthropogenic activities, e.g., burning of fuels. In the atmosphere, they exist in fine particles. POPs are man-made organic compounds that are resistant to degradation in the environment. Due to their features, such as toxicity to the environment and human health and bioaccumulation potential, the accumulation of POPs in the Arctic is of international concern (e.g., AMAP 2009; Letcher 2010).

\subsection{PAHs in aerosol}

PAHs are formed in combustion processes and are part of organic carbon fraction in fine particles (e.g., Saarnio 2013, Sillanpää et al. 2005, Sillanpää et al. 2006, Irei et al. 2017). However, PAH compounds in Europe are usually measured from $\mathrm{PM}_{10}$ aerosol fraction, that contains both fine and coarse fractions, according to the standard EN 15549:2008. FMI measures PAHs in the background areas in Finland, and the measurements and source apportionment of PAHs at Virolahti are presented in Paper V.

PAHs are formed during the incomplete combustion of organic material and are emitted into the atmosphere from several natural and anthropogenic emission sources. PAH molecules consist of two or more fused benzene rings, which may be arranged in linear, angular or cluster form and contain only carbon and hydrogen. PAH compounds can exist in both gas and particulate phases in the atmosphere. Lighter, highly volatile PAHs consisting of two or three aromatic rings exist in the gas phase, whereas heavier compounds with more aromatic rings are incorporated into particles in the atmosphere. However, gas-to-particle partitioning also depends on the ambient temperature (Seinfeld and Pandis 1998). These organic compounds form a complex toxic mixture of polycyclic organic matter that, either directly emitted or formed afterward in air, are of concern because of their toxicity to animals and humans. Many of these are possible human carcinogens due to their carcinogenetic nature. 
Natural PAH sources include emissions from volcanic activity and forest fires, whereas anthropogenic sources consist of fossil fuel and biomass burning (Ravindra et al. 2008). Wood combustion, especially in residential heating, is a significant PAH source in urban areas (Simoneit 1984, Cotham and Bidleman 1995), particularly in Northern Europe and, thus, also in Finland (Hellén et al. 2008, Hedberg et al. 2002, Glasius et al. 2008, 2018, Paper III).

Because of its origin, PAH concentration in the atmosphere typically has a clear annual cycle, being largest in wintertime and smaller during the warm season. During the cold season, emissions are higher due to residential heating using biomass and fossil fuels (Balmer et al. 2019). In addition to emissions, concentrations of PAH in the atmosphere are affected by light intensity, atmospheric conditions such as temperature inversion of the boundary layer, which prevents atmospheric mixing of pollutants, and long-range transport (e.g., Ravindra 2008; Lammel 2015).

The lifetime of PAHs is relatively low in the atmosphere, especially in gas-phase PAHs. Atmospheric oxidants, such as the hydroxyl radical and ozone, react with PAHs, and their lifetimes vary from a few hours to days. PAH degradation products, e.g., nitro- and oxy-PAHs, are formed in the atmosphere after combustion. As these PAH derivatives are not on the EU air pollutants list, there are no limits or target values determined for them, and there is no obligation to measure them in the air. However, the risk of these PAH derivatives should not be neglected (Alves et al. 2017).

In field measurements, it was found that particulate phase PAHs can be transported long distances in the atmosphere (Shimada et al. 2020). For particulate-phase PAHs, the atmospheric lifetimes may be increased due to secondary organic aerosol (SOA) coatings protecting PAHs from degradation by the ozone. Shimada et al. (2020) found that SOA coatings effectively shielded against PAH degradation, and especially PAHs originating from coal combustion were transported over long distances.

PAH compounds deposited in the soil can also stay there for long periods of time and then return to the atmosphere by evaporation from the soil in suitable conditions. Lighter compounds with higher volatility, such as lighter PAHs that exist mainly in the gas phase and compounds with higher water solubility, have a greater tendency toward this so-called grasshopper effect. In the grasshopper effect semivolatile compounds undergo more than one condensingevaporation cycle through the atmosphere, and while staying in ground (land or ocean), are shielded from atmospheric oxidative or light induced destructive stress (Lammel 2015, Shimada et al. 2020, Shrivastava et al. 2017).

Benzo(a)pyrene (b(a)p) is chosen as a marker for PAH cancer risk, and the European Commission has determined a target value of $1 \mathrm{ngm}^{-3}$ for annual average $\mathrm{b}(\mathrm{a}) \mathrm{p}$ concentration in $\mathrm{PM}_{10}$ aerosol (EU 2004, Papers III and V); this target value should not be exceeded. In addition to the target value, lower and upper assessment level values of 0.4 and $0.6 \mathrm{ngm}^{-3}$ were set. If the annual value is above the upper assessment level, fixed measurements are mandatory. If the annual value is between the upper and lower assessment levels, a combination of 
measurements and models can be used to estimate air quality in the area (EU 2004). According to Finnish national statistics (Figure 3), the b(a)p upper assessment level $\left(0.6 \mathrm{ngm}^{-3}\right)$ is quite commonly exceeded in many areas in Finland (Figure 2). Especially at Raahe Lapaluoto station, even the target value has been regularly exceeded. The site is located in the village near the steel factory, and it is still unclear whether the exceedances are due to the wood burning in the village and/or from the steel factory emissions or from both. However, ambient b(a)p levels are typically low, below the lower assessment level, in the Finnish background areas.
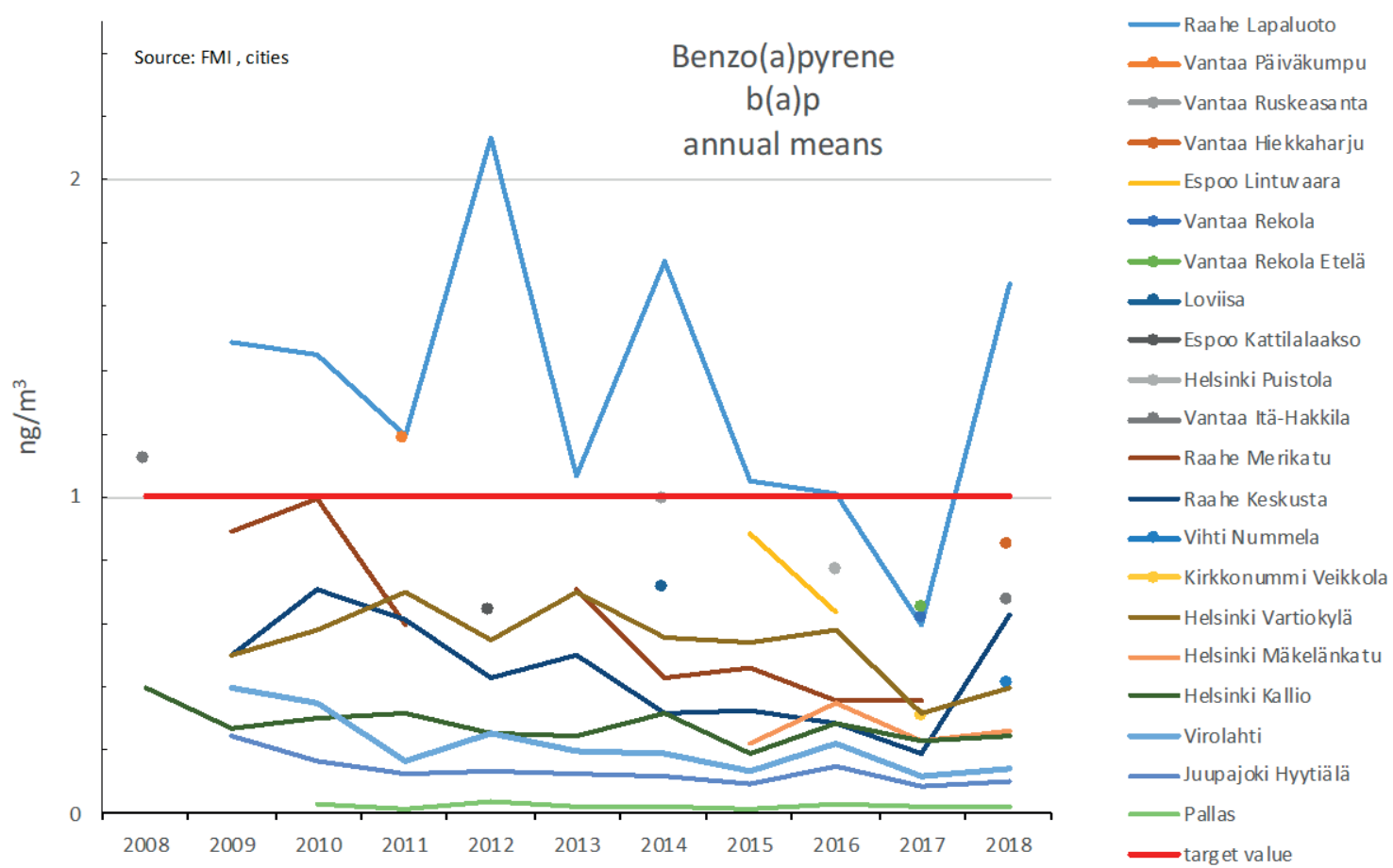

Figure 2. Mean annual b(a)p concentrations measured in Finland. Adopted from FMI 2021. Used with permission.

There are a lot of small towns and villages in Finland, where wood combustion is commonly used as the primary or secondary heating source during cold seasons. Wood combustion is also frequently used in one-family house areas, such as suburban areas in the Helsinki Metropolitan Area (HMA), as a secondary or additional heating source in addition to, e.g., the central district heating system or electric heating (Paper III). Annual measured ambient b(a)p concentrations in Europe (in 2018) and the population-weighed concentration map are shown in Figure 3. Measured ambient b(a)p concentrations are high in Eastern Europe, and therefore, there are many PAH measurements. In Finland, measurements are much fewer (figures 3 and 4). However, it has been estimated that the EU b(a)p upper assessment level value and even target value exceedances are quite common in many parts of Finland (Figure 3; ETC/ACM 2014/2020). This is due to intensive wood burning for heating, especially during cold seasons, and in sauna stoves. Residential wood burning is the largest single domestic fine particle source in Finland (Savolahti et al. 2019), and it has been estimated that two-thirds of b(a)p emissions in Finland originate from sauna stoves (Tissari et al. 2019). However, the PAH measurements are quite scarce in Finland, partly due to their labor-intensive laboratory analysis method and subsequent expensive analysis costs (Figures 3 and 4). 


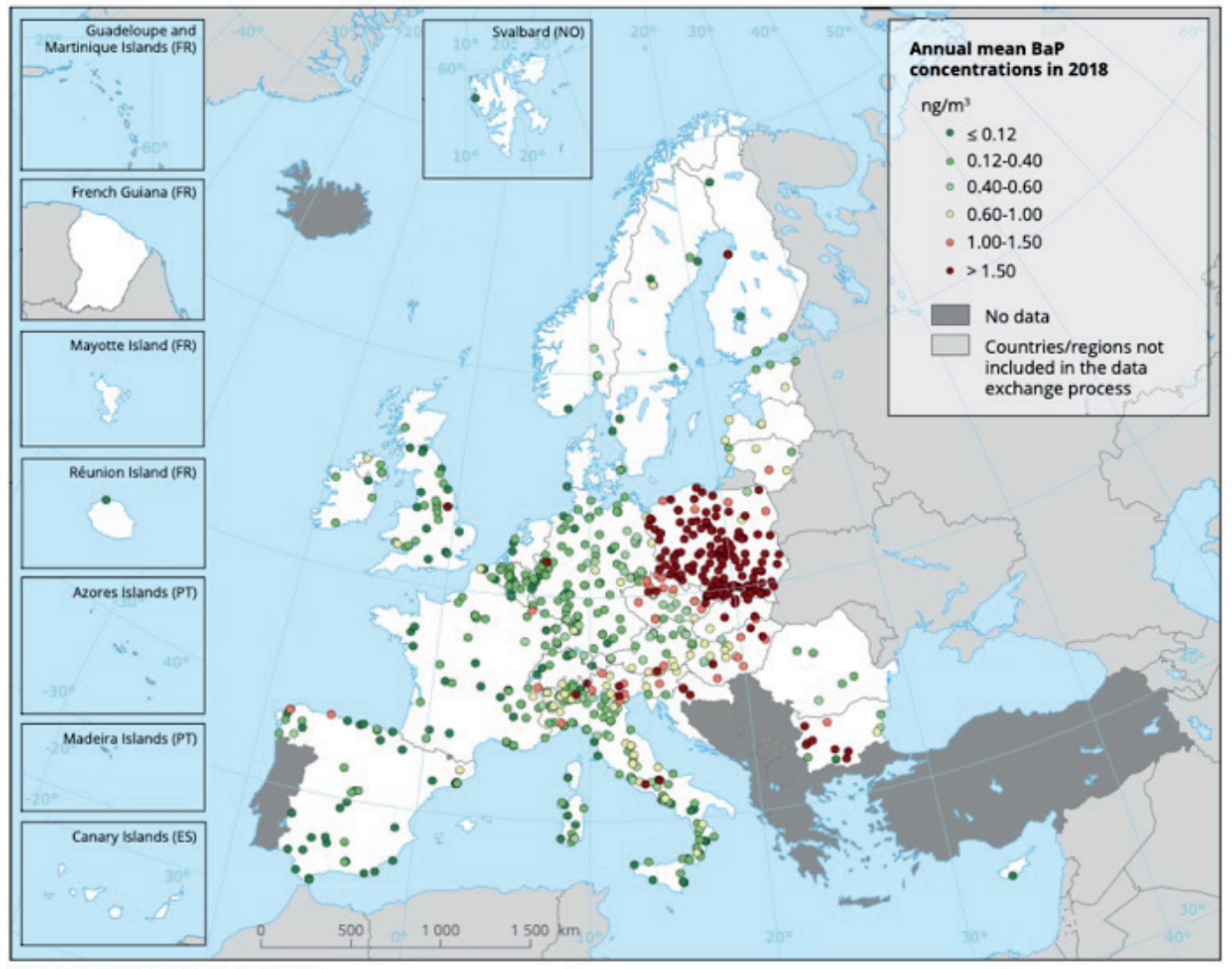

Reference data: EESRI | OEuroGeographics

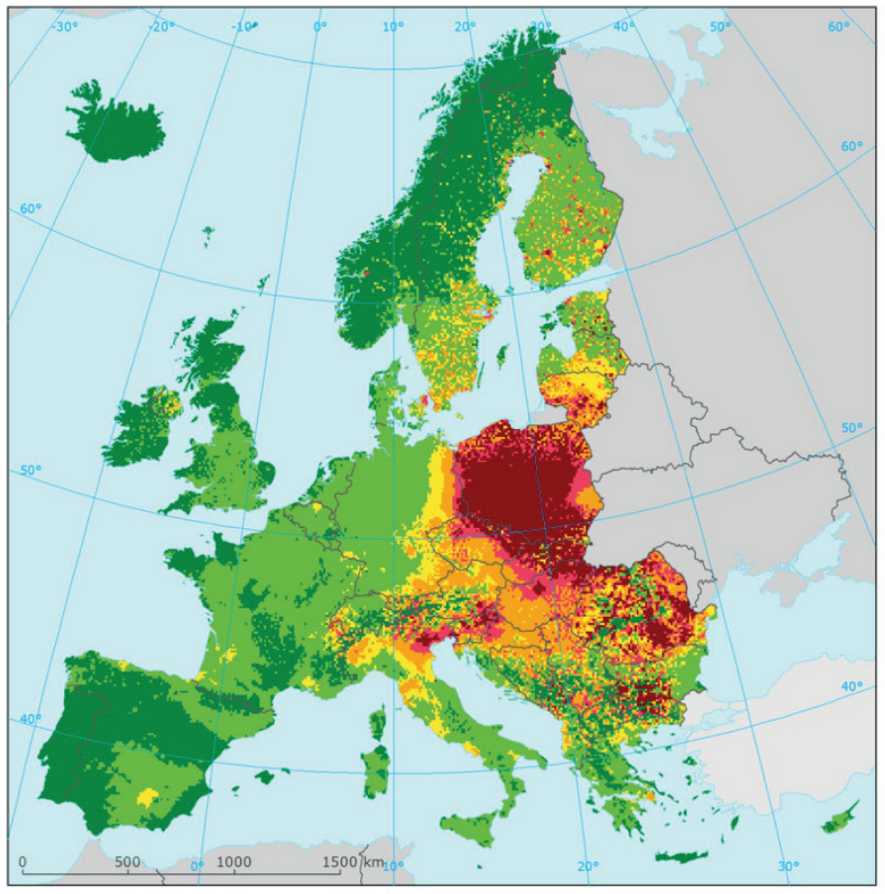

\begin{tabular}{l} 
Benzo(a)pyrene \\
Annual Average \\
Reference Year: 2012 \\
Population Weighted Concentration Map \\
Model Used in Mapping: EMEP \\
Resolution: $10 \times 10 \mathrm{~km}$ \\
$\leq 0.12 \mathrm{ng} \cdot \mathrm{m}^{-3}$ \\
$0.12-0.4 \mathrm{ng} \cdot \mathrm{m}^{-3}$ \\
$0.4-0.6 \mathrm{ng} \cdot \mathrm{m}^{-3}$ \\
$0.6-1 \mathrm{ng} \cdot \mathrm{m}^{-3}$ \\
$1-1.5 \mathrm{ng} \cdot \mathrm{m}^{-3}$ (1 = TV) \\
$>1.5 \mathrm{ng} \cdot \mathrm{m}^{-3}$ \\
$\square$ outside data coverage \\
$\square$ poor data coverage \\
\hline
\end{tabular}

Figure 3. Annual mean b(a)p concentration in Europe in 2018 (upper figure) and EMEP model result for population-weighed annual average for $b(a) p$ concentrations in Europe in the year 2012 (lower figure). Target value exceedances and population exposure to concentrations above target value are quite common in Eastern Europe. Figures originally presented in EEA Report 
No 9/2020: Air quality in Europe - 2020 report (upper figure, ETC/ACM 2020) and ETC/ACM Technical Paper 2014/6 European Topic Centre on Air Pollution and Climate Change Mitigation (lower figure, ETC/ACM 2014).

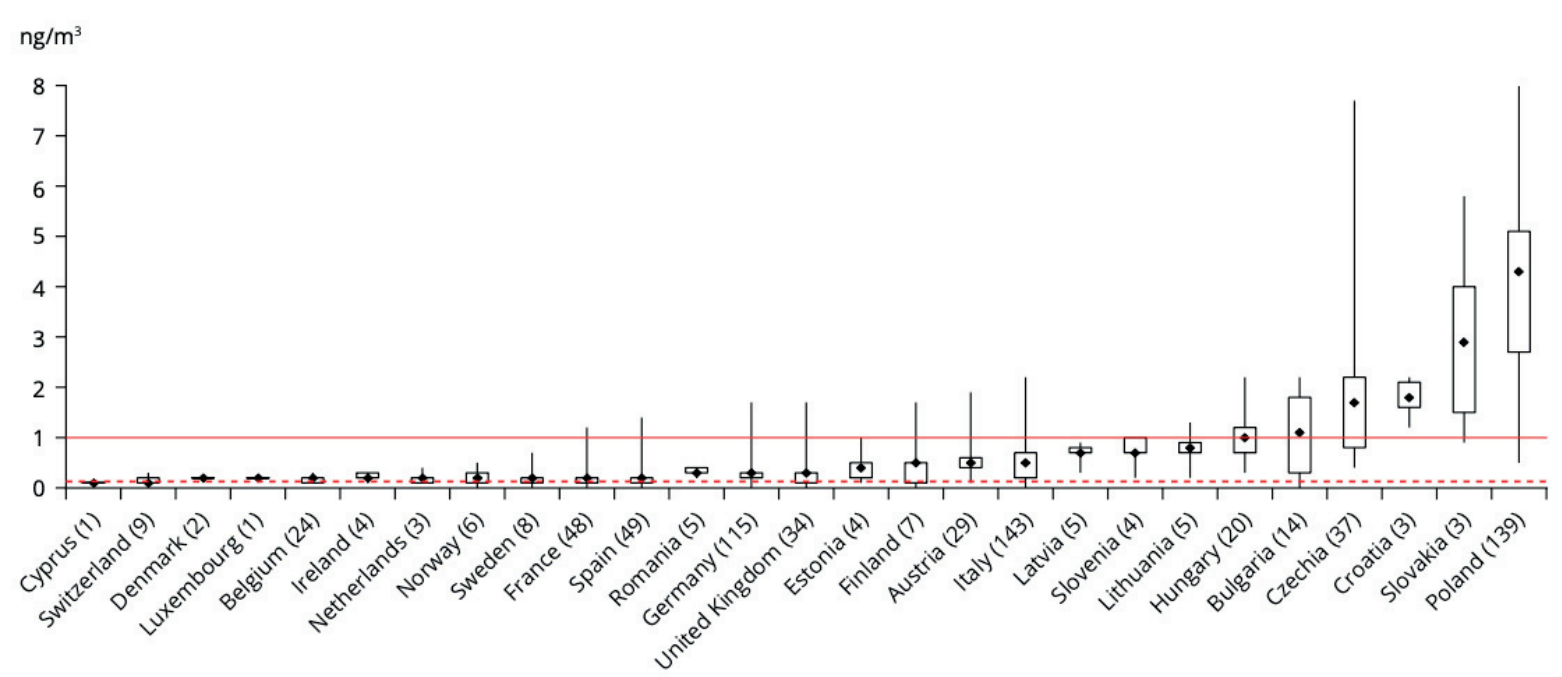

Figure 4. Annual mean b(a)p concentrations in $\mathrm{PM}_{10}$, measured in Europe in 2018. The amount of the reported measurements is in the brackets after the country name and the lowest, average, and highest values (in ngm $^{-3}$ ) are given. The rectangles mark the 25 th and 75 th percentiles. The upper horizontal red line marks the target value of $1 \mathrm{ngm}^{-3}$. The lower horizontal line is the WHO air quality reference level (RL, $0.12 \mathrm{ngm}^{-3}$ ), which is an estimated unit risk for $\mathrm{PAH}$ mixtures and describes an acceptable risk of additional lifetime cancer risk of 1/100000 people (WHO 2010, ETC/ACM 2020). Figure originally presented in EEA Report No 9/2020: Air quality in Europe - 2020 report (ETC/ACM 2020).

\subsection{Persistent organic compounds in the environment}

Some pollutants like dioxins and polychlorinated biphenyls PCBs and other so-called persisted organic pollutants (POPs) are remarkably resistant against decomposition and are thus longlived in nature, which means that after their release into the environment, they stay unconverted for a long time, or their degradation is slow. Therefore, these compounds tend to accumulate in the environment. They can be attached in the atmospheric particles, and because of their long half-lives in soil, water, and air, POPs can be transported long distances. Due to their persistent nature, many of these POPs are rather ubiquitous, and they are found even in remote Arctic areas, far from their original emission sources. Many of these compounds are toxic, and therefore, their accumulation in the environment and, e.g., their transfer along the food chain is an important issue.

Like PAHs, depending on the ambient temperature, these species can be in a gas phase or attached into the particles. During cold winter periods, most of the POPs are in particles, whereas during summer, the most volatile of these compounds exist in the gas phase. 
Atmospheric transport is probably the most important transfer route for POPs (AMAP 2004, Hung et al. 2016, Wong et al. 2021)

Acknowledging that POP compounds in the environment are causing a major and increasing threat for the environment and human health, the need to restrict the production and use of these toxic compounds was internationally recognized by the United Nations Environmental Programme (UNEP). The Stockholm Convention created international restrictions of production, and restricted use or ban of certain toxic compounds came to force in 2004 (UNEP 2019).

Common characteristics for all POPs are low water solubility and high lipophilicity, with long resistance times for degradation in air and soil. Because of these characteristics, these compounds tend to accumulate into the fat tissues of animals and eventually into humans at the top of the food chain (AMAP 2009. POPs deposited in the soil can stay there several years, and when conditions are suitable, e.g., in the summertime, these compounds can evaporate from the soil back to the atmosphere. The oceans also work as deposition sinks in a similar manner, and compounds can be transferred via the sea currents for long distances and evaporate from there back to the atmosphere. Semi-volatile compounds can undergo one or more volatilizationtransport-deposition cycles. The volatilization and deposition rate, as well as residence time in the soil (or sea), depends on the volatility and water solubility of the compounds and ambient conditions like temperature. This grasshopper effect exists both on continents and in oceans and is a significant transport pathway from the mid to high latitudes, especially for POPs with low degradability but also for PAHs. This grasshopper effect explains why POPs are measured in remote northern areas with no significant (or none at all) local or near-pollution sources. This deposition cycle also partly explains why certain compounds whose emissions have been reduced by international reduction or ban of use, like PCBs, can still be found in the air (Semeena and Lammel 2005, Lammel et al. 2015, Balmer et al. 2019).

The levels of many POPs are now declining in the Arctic, mainly due to global restrictions and ban of use in most countries, but the pollutant levels of many POP compounds are still high enough to cause health effects in animals, especially predators that exist at the top of the food chain and eventually humans too (e.g., Sobek and Gustafsson 2014). It has been estimated that even half of the PCBs ever produced in the world are still somewhere in landfills or in old electricity equipment like transformers. Climate change and global warming may also affect the global contamination pathways and redistribution of contaminants by resuspending them once they are deposited into the soil and sea ice (AMAP 2009, Hung et al. 2016, Anttila et al. 2016, Cabrerizo et al. 2018, Wong et al. 2021).

\subsection{Volatile organic compounds}

Volatile organic compounds (VOC) are released into the air from various anthropogenic sources, i.e., traffic, heating, and industry. After their emission into the atmosphere, they react 
with atmospheric oxidants with different reaction rates. Lifetimes of atmospheric VOCs vary from seconds or a few minutes to days, months, or even years, like with certain halogenated hydrocarbons (Hellén 2006). Large amounts of biogenic volatile organic compounds

(BVOCs) (e.g., isoprene, monoterpenes, and sesquiterpenes) are emitted into the atmosphere by vegetation, especially in the densely forested boreal regions by trees, understory vegetation, and soil (Hakola et al. 2001, 2006, Tarvainen et al. 2005, 2007, Hellén et al. 2006, Wiedinmyer et al. 2004, Steiner and Goldstein 2007).

Despite massive global anthropogenic air pollution, biogenic sources emit the major portion of the atmospheric VOCs (Guenther et al. 2012, Hallquist et al. 2009). Sources of BVOCs and their oxidation products emitted in the boreal forest were studied in Papers I and IV.

\subsection{Oxidation products of BVOCs}

Some volatile organic compounds like terpenes and sesquiterpenes are highly reactive, and they react after emission into the atmosphere with atmospheric oxidants such as ozone and $\mathrm{OH}$ and $\mathrm{NO}_{3}$-radicals, resulting in reaction products, e.g., organic acids, carbonyl-containing compounds, and highly oxygenated organic molecules (HOM). The produced oxidized compounds are heavier than their precursors and tend to have lower vapor pressure, so they can participate in the formation and growth of new particles (Figure 5) via condensation on the existing particles, or they can form new particles by nucleation if the ambient conditions are suitable (Kulmala et al. 2004, Tunved et al. 2006, Ehn et al. 2014, Quéléver et al. 2019, Zhao et al. 2021). It has been estimated that organic compounds account for even $20-90 \%$ of the total fine particle mass in a variety of atmospheric environments (Kanakidou et al. 2005). Therefore, research on VOC emissions from, e.g., boreal forests and on their particle forming potential is important. 


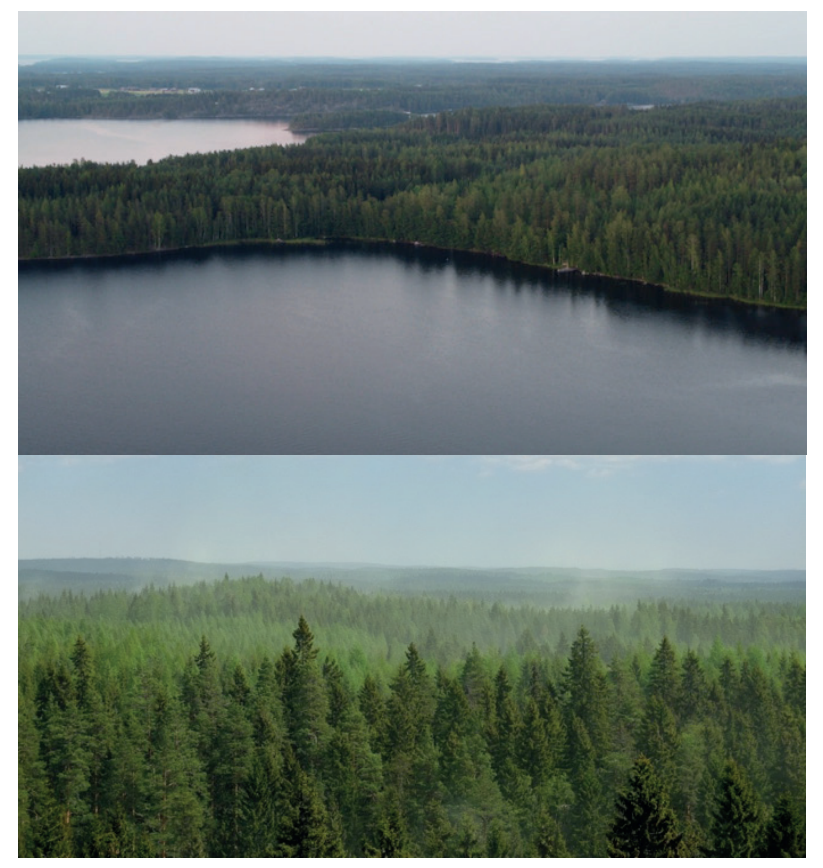

Figure 5. Blue haze, secondary organic aerosol formation over a boreal forest on Lapinsalo Island, Savitaipale (above) and Hyytiälä. Organic compounds emitted from vegetation are oxidized in the atmosphere and are condensed into existing particles or form aerosol via nucleation. This is seen as haze over the forest. Photo credits: Author and Juho Aalto. Used with permission.

Sesquiterpenes (SQTs) have a particularly high tendency for aerosol formation and, thus, they also have the potential to cool the climate (Khan et al. 2017). The selected organic acids pinic, pinonic, caric limonic, and caryophyllinic acids, were measured from fine particles in the boreal forest in order to estimate their influence on aerosol production in that area (Paper IV). These acids are the oxidation products of $\alpha$ - and $\beta$-pinene, limonene, $\Delta 3$-carene, and $\beta$-caryophyllene, which are the main mono- and sesquiterpenes in boreal areas. As standards for caric, limonic, and caryophyllinic acids were not commercially available, they were synthesized in the study.

\subsection{Source apportionment}

Source apportionment is a common name for a group of statistical methods that are used for source identification. Several source apportionment methods have been developed and used in the world since the 1980s (Belis et al. 2013). There are two common approaches to resolve source contributions, source-oriented models (dispersion models), and receptor models. Dispersion models use emission data to predict concentrations at a certain point (receptor). Receptor models are used to identify air pollution sources by using measured time series of existing air pollutants and knowledge of the studied pollutants and their behavior in the atmosphere (Hopke 2016).

The most common receptor-oriented models are chemical mass balance (CMB, Schauer et al. 1996) and positive matrix factorization (PMF, e.g., Paatero 1997, Paatero and Hopke 2003).

CMB uses measured emission source profiles (e.g., biomass burning, traffic) for source identification; PMF uses chemical composition data to predict source profiles and does not need existing profiles for source apportionment, but they are, of course, helpful in identifying and 
recognizing the most reasonable model solution. The PMF model is widely used for ambient air quality research across the world, but it can also analyze other kinds of environmental sample data, like wet deposition, water quality, sediments, indoor air, etc. Traditionally, PMF has been used for source apportionment of particulate matter, e.g., $\mathrm{PM}_{10}$ and $\mathrm{PM}_{2.5}$ (e.g., Almeida et al. 2020), but it has also been applied to the combination of species measured from different phases like PM and gases or to measurements of different time resolution (e.g., Belis et al. 2019, Srivastava et al. 2019, Papers I and II), such as for $\mathrm{PM}_{2.5}$ and gaseous pollutant data (e.g., Kampf et al. 2012, Crippa et al. 2014), PAHs in $\mathrm{PM}_{10}$ and gaseous pollutant data (e.g., Paper V), and particle number size distributions (e.g., Squizzato et al. 2019). However, in earlier studies, biogenic sources have not been specified in detail, but as a common biogenic source (e.g., Sarkar 2017, Li et al. 2019, McCarthy et al. 2013). In this thesis, biogenic sources in the boreal forest were specified in detail using PMF, according to our knowledge, for the first time (Paper I). PMF was also used as a source apportionment method for trace metals (Paper II), PAHs (Paper V) and POPs (unpublished data). 


\section{EXPERIMENTAL}

\subsection{Research sites}

All measurements have been conducted in Finland (Figure 6 and Table 1). Measurement data from the Finnish background sites Hyytiälä, Pallas and Virolahti were used in Papers I, II, IV and V. Pallas POPs measurements were used for source apportionment results, which are presented later in this thesis. In Paper III, measurement data and statistics from Helsinki Region Environmental Services (HSY) were used for the research.

Table 1. Measurement sites and sampling periods used in this thesis

\begin{tabular}{|c|c|c|c|}
\hline Site location & Site type & $\begin{array}{l}\text { Measurement } \\
\text { period }\end{array}$ & Paper \\
\hline Hyytiälä & $\begin{array}{l}\text { Rural } \\
\text { background } \\
\text { (boreal forest) }\end{array}$ & $\begin{array}{l}2016 \\
2011-2012\end{array}$ & $\begin{array}{l}I \\
I V\end{array}$ \\
\hline Pallas & $\begin{array}{l}\text { Sub-arctic } \\
\text { remote } \\
\text { background }\end{array}$ & 1996-2018 & II \\
\hline Virolahti & $\begin{array}{l}\text { Rural } \\
\text { background }\end{array}$ & 2007-2008 & $V$ \\
\hline $\begin{array}{l}\text { Various } \\
\text { locations in } \\
\text { Helsinki } \\
\text { Metropolitan } \\
\text { Area (HMA) }\end{array}$ & $\begin{array}{l}\text { Urban, Urban } \\
\text { background }\end{array}$ & 2007-2015 & III \\
\hline
\end{tabular}

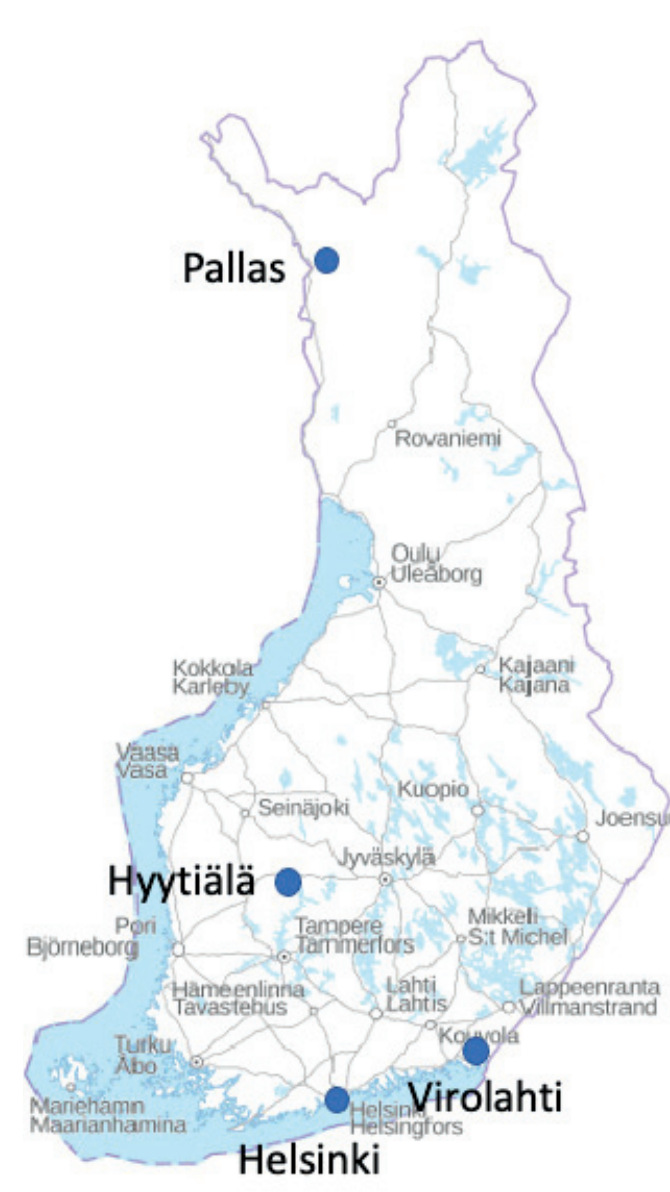

Figure 6. Sampling locations.

\subsection{Sampling techniques}

Sampling of trace elements and PAH in particulate matter on filters with a defined flow rate were conducted using reference samplers with size-selective inlets $\left(\mathrm{PM}_{10}\right.$ and $\left.\mathrm{PM}_{2.5}\right)$ on Teflon filters, according to standard method EN 12341 (CEN 2014). Biogenic acid sampling was 
conducted using a custom-made low-volume sampler (Figure 7) with a sampling flow of 16 LPM, also onto Teflon filters. POPs were sampled using a high-volume sampler with a flow rate of approximately $25 \mathrm{~m}^{3} / \mathrm{h}$, resulting in an approximate $4000 \mathrm{~m}^{3}$ weekly sample volume on glass-fiber filters followed by polyurethane foam. Both gas and particle fractions were combined for POP analysis. Sampling and analysis methods are listed in Table 2.

Table 2. Sampling and analysis methods used in this work

\begin{tabular}{|c|c|c|c|c|}
\hline Site location & Sample & Matrix & Analysis method & $\begin{array}{l}\text { Source } \\
\text { apportionment } \\
(P M F)\end{array}$ \\
\hline \multirow{3}{*}{ Hyytiälä } & VOCs & Gas & $T D-G C-M S$ & $x$ \\
\hline & Biogenic acids & $P M_{2.5}$ & HPLC-ESI-ITMS & - \\
\hline & $\mathrm{NO}_{x}, \mathrm{O}_{3}, \mathrm{SO}_{2}$ & Gas & Gas monitors & $x$ \\
\hline \multirow{5}{*}{ Pallas } & Trace elements & $P M_{10}$ & $G C-M S$ & $x$ \\
\hline & POPs & Gas/TSP & $\begin{array}{l}H P L C-F L D, G C- \\
F L D\end{array}$ & $x$ \\
\hline & $\mathrm{NO}_{x}, \mathrm{O}_{3}, \mathrm{SO}_{2}$ & Gas & Gas monitors & $x$ \\
\hline & Total beta activity & Aerosol & $\begin{array}{l}\text { Alpha/beta } \\
\text { analyzer }\end{array}$ & $x$ \\
\hline & PM mass & $P M_{10}$ & PM mass monitor & \\
\hline \multirow[t]{3}{*}{ Virolahti } & $P A H$ & $P M_{10}$ & $G C-M S$ & $x$ \\
\hline & $N O_{x}, O_{3}, S_{2}$ & Gas & Gas monitors & $x$ \\
\hline & PM mass & $P M_{10}$ & PM mass monitor & $x$ \\
\hline $\begin{array}{l}\text { Various locations } \\
\text { in }\end{array}$ & PM mass & $P M_{10}$ & $\begin{array}{ll}\text { PM mass } \\
\text { monitors }\end{array}$ & - \\
\hline $\begin{array}{l}\text { Helsinki } \\
\text { Metropolitan Area } \\
(\text { HMA) }\end{array}$ & $P A H$ & $P M_{10}$ & $G C-M S$ & - \\
\hline
\end{tabular}


PTFE filters have been found suitable for collecting PM and for determining PM mass and chemical composition in Finland and the Nordic countries (e.g., Waldén et al. 2017, Kyllönen 2020) due to low contamination, inertness to moisture and ease of handling due to high mechanical strength. PTFE filters are routinely used in Finland for PAH, heavy metals, and ion sampling, and also in PM mass determination using the reference method. In organic PM sampling, as in Paper IV, quartz filters are more suitable than PTFE because low clogging due to small back pressure makes it possible to sample relatively long periods, and they can be cleaned from organic contamination by baking them prior to sampling (Kulkarni et al. 2011).

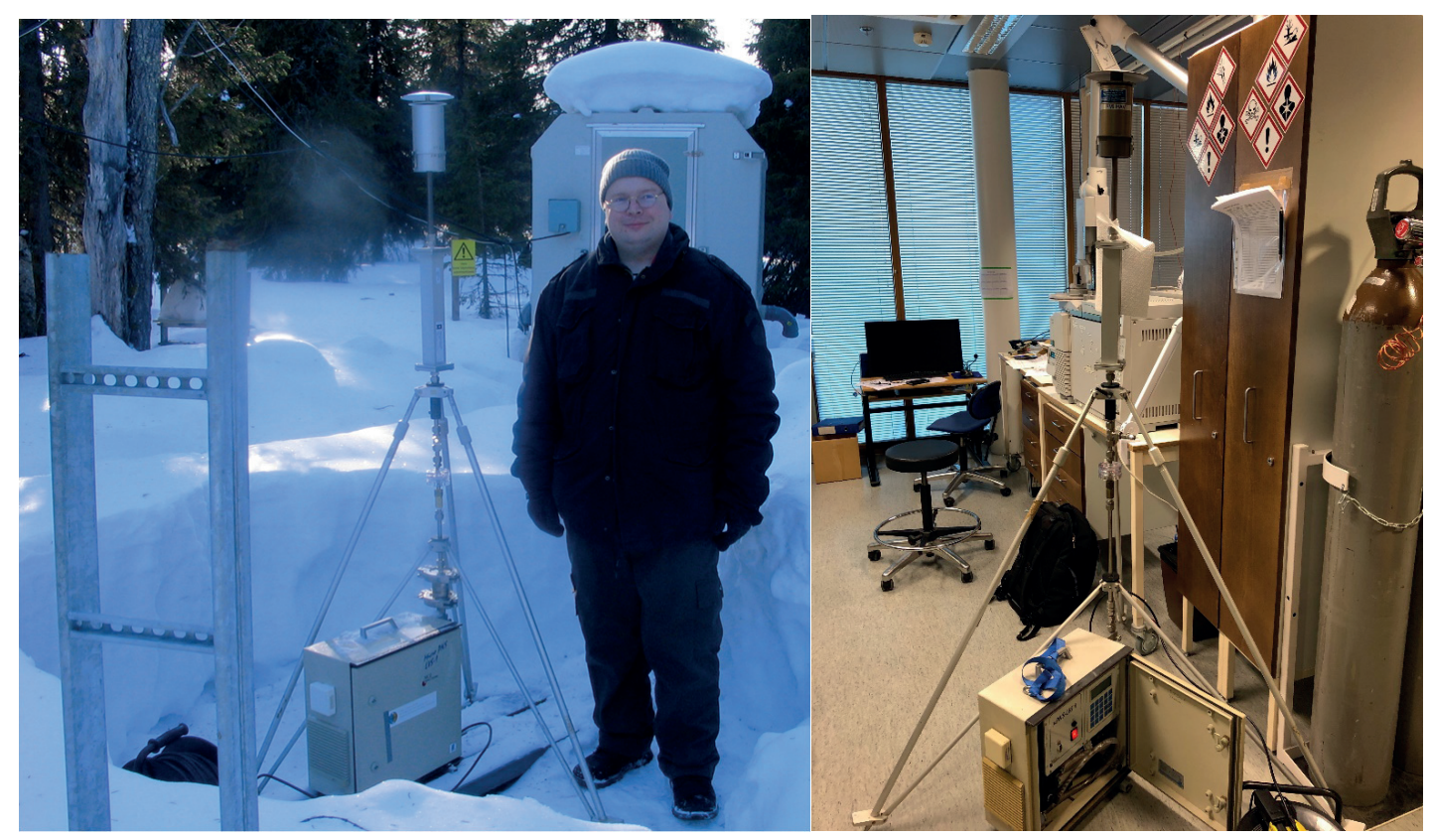

Figure 7. Custom-built biogenic acid sampler $\left(\mathrm{PM}_{2.5}\right)$ in the laboratory and in the field.

Size-selective inlets or impactors (Figure 8) have been commonly deployed to segregate the desired sized particles to determine PM mass and chemical composition in PM. Aerodynamic inlets for $\mathrm{PM}_{10}$ and $\mathrm{PM}_{2.5}$ particle fractions are the most commonly used inlets in the world. The EU is following EN standard EN 12341 (CEN 2014). USEPA has its own PM inlet construction according to their standard (USEPA 2013). 


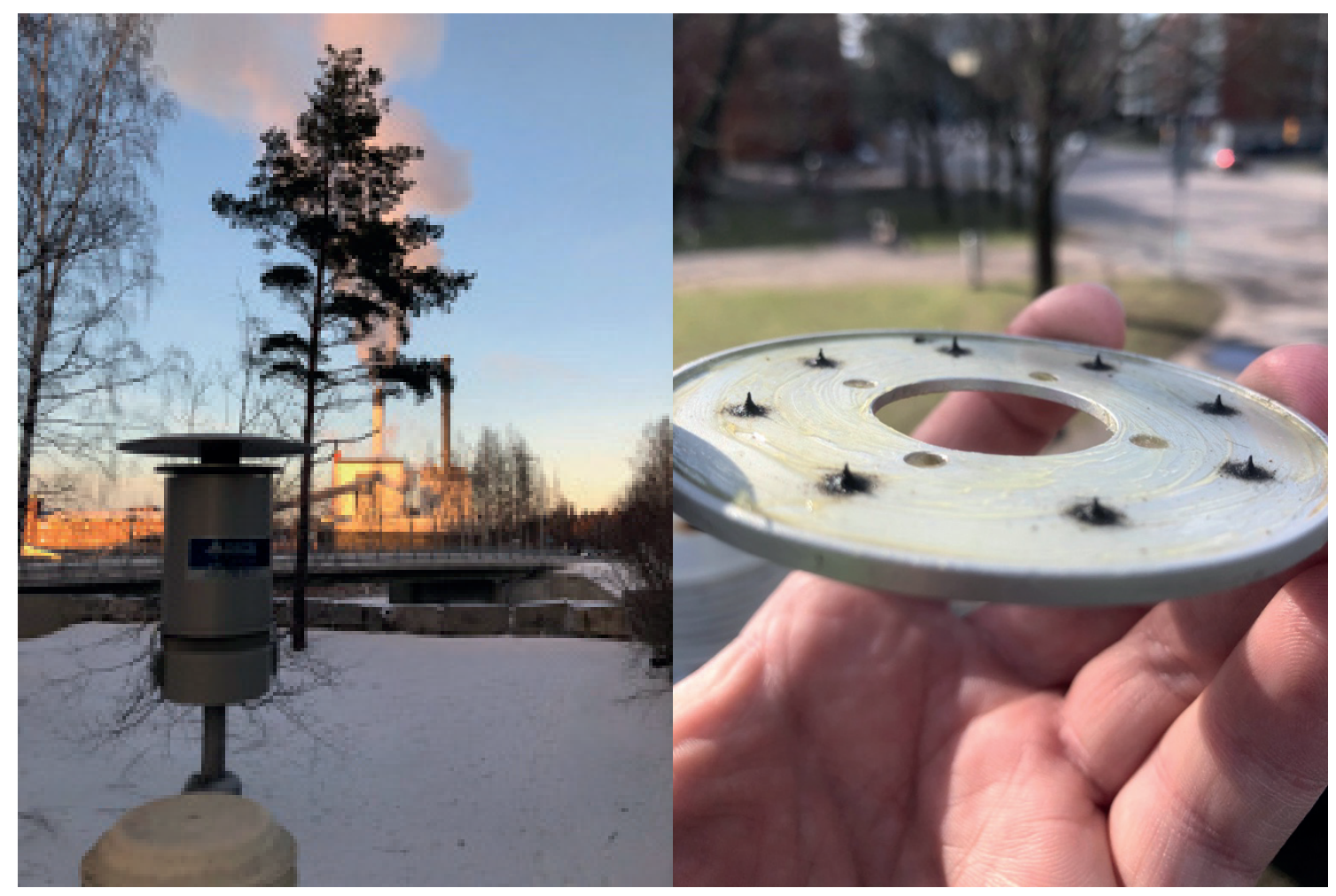

Figure 8. Aerosol sampling head (size-selective inlet) and its $\mathrm{PM}_{2.5}$ impactor plate.

\subsection{Chemical analyses}

\subsubsection{BVOC analysis}

VOC concentrations in the boreal forest were analyzed using gas chromatograph-mass spectrometer equipped with thermal desorber injector (TD-GC-MS). The samples were $30 \mathrm{~min}$. at 1- to 3-hour resolution in the thermal desorber cold trap and analyzed with Clarus $680 \mathrm{GC}$ using HP-5 column (60 m; i.d. $0.25 \mathrm{~mm}$; film thickness $1 \mu \mathrm{m}$ ) and Clarus SQ 8 T MS (Papers I and IV).

\subsubsection{Biogenic organic acid analysis}

High-performance liquid chromatography (HPLC) methods with mass spectrometric or fluorescence detector are common for analyzing organic acids in SOA as the methods are sensitive, and polar carboxylic acids are well suited for LC analysis without, e.g., derivatization. However, other off-line methods have also been used, like different LC methods (e.g., Cui et al. 2018), 2-dimensional GC (e.g., Worton et al. 2017), infrared ion spectroscopy (Walhout et al. 2019), and combined in-situ gas chromatographic and mass spectrometric methods with online derivatization (e.g., Isaacsman et al. 2014).

In this work, a method to analyze biogenic acids (pinic, pinonic, caric limonic, and 
caryophyllinic) from $\mathrm{PM}_{2.5}$ samples were developed. The aerosol samples from Hyytiälä were extracted into methanol and analyzed using HPLC combined with electrospray ionization ion trap mass spectrometer as detector (HPLC-ESI-ITMS). Camphoric acid was used as an internal standard. Each of the compounds was measured individually, first using the mass spectrometer's scan mode to determine the retention times and representative ions for each compound from the standard solution and second with the selected ions measured in multiple reaction monitoring mode. Caric, limonic, and caryophyllinic acids were synthesized for this campaign by the Laboratory of Organic Chemistry, Chemistry Department, University of Helsinki, as they were not commercially available.

\subsubsection{Ion analysis}

Ions were analyzed using ion chromatography. Three-stage filter packs were used daily for the sampling of $\mathrm{SO}_{4}-\mathrm{S}, \mathrm{Na}, \mathrm{K}, \mathrm{Ca}, \mathrm{Mg},\left(\mathrm{NH}_{3} \mathrm{NH}_{4}\right) \mathrm{N}$, and $\left(\mathrm{HNO}_{3} \mathrm{NO}_{3}\right) \mathrm{N}$ in air according to the EMEP manual (EMEP, 1996). These samples were analyzed by ion chromatography in FMI. The ion analysis method is described in Ruoho-Airola et al. (2015) (Papers II and V).

\subsubsection{Trace element analysis}

Trace element analyses were performed at the FMI Laboratory before 2010 (Paper II). Starting in 2010, the trace analyses were made by the Finnish Environment Institute SYKE (Paper II). Weekly trace element filter samples were collected with a low-volume sampler on the roof of Pallas Matorova and analyzed with ICP/MS.

\subsubsection{PAH analysis}

PAHs were analyzed using gas chromatograph-mass spectrometer (GC-MS) following standard EN 15549:2008 (CEN 2008) (Papers III and V). Among the 16 EPA priority PAH pollutants, 11 were studied (phenanthrene, anthracene, fluoranthene, pyrene, benz(a)anthracene, chrysene/triphenylene, benzo(k_b_j)fluoranthene, benzo(a)pyrene, benzo(ghi)perylene, indeno(123-cd)pyrene, and dibenz(ah $\mathrm{p}$ ac)anthracene). GC-MS was used to analyze soxhletextracted $\mathrm{PM}_{10}$ samples in dichloromethane (DCM), using the internal standard method for sample recovery following the EN 15549:2008 standard method.

\subsubsection{POP analysis}

POP samples were analyzed in IVL's (Svenska Miljöinstitutet, Swedish Environmental Research Institute ) laboratory using HPLC/FLD and GC/ECD. The analysis method is described in Anttila et al. (2016). These POP data were then combined with heavy metal, ion, and gas data and beta activity data from FMI and the whole dataset was used for the POP source apportionment study. Measured POP compounds were six PCB compounds (PCB28, $52,101,138,153$ and 180), $\alpha$ - and $\gamma$-(gamma) hexachlorocyclohexanes (HCHs), dichlorophenyltrichloroethane (DDT) and its decay products, dichlorodiphenyldichloroethane 
(DDD), and dichlorodiphenyldichloroethylene (DDE), hexachlorobenzene HCB, $\alpha$ - and $\gamma-$ chlordans, trans-nonachlor, and polybrominated diphenyl ethers (PBDEs) (47, 99, and 100).

\subsubsection{Total beta radioactivity analyses}

Total beta activities of aerosol samples from Sodankylä were measured in FMI five days after the end of sampling. During this delay period, the short-lived radon-222 progeny decayed to $\mathrm{Pb}-210$, and the Rn-220 daughter nuclides decayed to stable lead. The total beta activities were assayed with an automatic alpha/beta analyzer equipped with large-area gas-flow proportional counters (Mattsson et al. 1996).

\subsubsection{Online measurements}

$\mathrm{SO}_{2}$ was measured using a UV fluorescence analyzer (Thermo Environmental TEI43CTL), $\mathrm{NO} / \mathrm{NO}_{2}$ using a chemiluminescence $\mathrm{NO}_{\mathrm{x}}$ analyzer (Thermo Environmental TEI42CTL), and $\mathrm{O}_{3}$ using a UV absorption analyzer (Thermo Environmental TEI49C). PM mass ( $\mathrm{PM}_{10}$ and $\mathrm{PM}_{2.5}$ ) was monitored with a beta attenuation analyzer (Thermo-ESM-Andersen FH62 IR). Total gaseous mercury (TGM) was measured with a Tekran 2537A mercury vapor analyzer (Papers II and III). 


\section{DATA ANALYSIS}

The PMF method was used for source apportionment in Papers I, II and V. Source apportionment was made to identify the sources of the PAHs, POPs, trace elements, and BVOCs in the daily and weekly (Paper V), weekly (Paper II), and hourly samples (Paper I). The Virolahti dataset used in Paper V was analyzed using EPA PMF version 3 (USEPA 2008). The Hyytiälä short-sample dataset (Paper I), the Pallas trace metal dataset (Paper II), and the POP dataset were analyzed using EPA PMF version 5.0 (USEPA 2014).

PMF (Paatero and Tapper 1994, Paatero 1997) is a receptor modeling tool that is widely used in the source apportionment of air pollution (Hopke 2016, Hopke et al. 2020). The PMF model result can, at best, resolve pollution sources that impact the measuring site during the time of the measurement. The model result is greatly dependent on the user expertise and knowledge of the modeled area. The pollutant source may have a certain distinct combination of pollutant species, which may or may not undergo modification in the atmosphere during transport from pollution source to receptor site, where pollution time series are measured. Source intensity may also vary during measurement, which often gives useful information for the interpretation of the model result. The PMF model can use measured chemical composition data of selected PM fraction, but external gas monitor measurements can also be used. These were used in all three datasets. Also, external meteorological data (e.g., wind direction and speed, air mass trajectories) can be utilized along with the model result. These were utilized to resolve pollution source directions and/or source areas (Papers I, II, and V).

In this thesis, PMF was used for resolving the sources of volatile organic compounds and their oxidation products in the boreal forest in Hyytiälä (Paper I). A total of 1220 1-2-hour VOC samples of individual monoterpenoids, sesquiterpenes, C5-C10 aldehydes, 2-methyl-3-buten1-ol (MBO), methacrolein (MACR), benzene, and toluene were measured between April and November, 2016. Here, the model included quasistationary emission sources of biogenic VOCs and their reaction products in the boreal forest, where sources of emission products were formed on the way from the source to the receptor. Due to high reactivity, VOC emission profiles and measured profiles at the receptor are not fully comparable. These are challenging situations regarding source apportionment, and the model user must be aware of that. This was acknowledged in the interpretation of the results where sources of biogenic VOCs were estimated.

In addition to this VOC dataset, additional gas data $\left(\mathrm{NO}_{\mathrm{x}}, \mathrm{SO}_{2}\right.$, and $\left.\mathrm{O}_{3}\right)$ were also used to support the modeling. The 10 -factor solution was selected as it was most reasonable to the interpretation of the source profiles, concentration time series, diel patterns, and the lowest number of scaled residuals. According to the model uncertainty analysis (bootstrapping and displacement analysis, e.g., Paatero et al. 2014), the selected solution was robust. Model constraints were used for the weak species longicyclene and b-farnesene to prevent their domination. Local wind data were used for conditional bivariate probability function (CBPF) 
analysis for each resolved factor using the OpenAir package in R (Uria-Tellaetxe and Carslaw 2014; Carslaw 2018).

In Paper V, source apportionment was used for resolving sources that had impact on the air quality, especially on PAH concentrations at Virolahti. Datasets with $\mathrm{PM}_{10}$ aerosol chemical characterization data (main ions and PAHs in $\left.\mathrm{PM}_{10}\right)$ and gas data $\left(\mathrm{SO}_{2}, \mathrm{NO}, \mathrm{NO}_{2}\right.$ and $\left.\mathrm{O}_{3}\right), \mathrm{n}=51$, were modelled using USEPA PMF 3.0 (USEPA 2008). Three- to seven-factor solutions were run, and three-factor solution was selected because it gave a good fit to the data and was the most interpretable. In all solutions, most PAHs made their own factors, and more than three solutions did not bring extra information about the PAH sources. Also, the dataset was reasonably small, and with the three-factor solution, we were on solid ground with the interpretation. Wind data were used for the modeling result using the continuous probability function (CPF) in Excel.

PMF was also used to resolve the pollution sources at Pallas (Paper II). Modeled data consist of trace elements, main ions, EC/OC and gases, including total gaseous mercury, with a focus on trace elements. The modeled time series was long, including 22 years of weekly sampling of heavy metals. All modeled data were averaged according to heavy metal data. There were also missing data, as all of the components were not measured all the time. For missing data, the time series median was used to fill the gap in the modeled data, and the uncertainty for that datapoint was increased at least tenfold so that those datapoints would not affect the final result. For example, for components like TGM, EC, and OC, the correlation between modeled and measured data was not good; this is probably also due to a relatively high amount of missing measurement data for these components. Bootstrapping was used to estimate the uncertainty and solidness of the selected result, and the bootstrap result for the selected solution was good. Source regions of PMF factors were estimated using potential source contribution function (PSCF) for trajectory analysis of $120 \mathrm{~h}$ FLEXTRA air mass back trajectories (Stohl et al. 1995, Stohl and Seibert 1998) using R. The NOAA Hybrid Single-Particle Lagrangian Integrated Trajectory (HYSPLIT) model (Stein et al. 2015, Rolph et al. 2017) was utilized to interpret single peak values in Papers II and III. Trajectories were calculated using the Global Data Assimilation System (GDAS) archive (NOAA 2016).

Later, persistent organic pollutant data measured in Pallas by the IVL was added to data previously used in the trace elements dataset, and these data were modeled, focusing this time on POPs. Data were examined and re-averaged according to weekly POP data. The most robust solution, the five-factor solution, was selected, like the trace element data in Paper II. Similarities from trace element modeling result supported the POPs solution, but new information about the sources of POPs was also discovered. PSCF source regions for each factor were calculated in R, similarly to Paper II. 


\section{RESULTS}

\subsection{Sources of organic compounds in aerosols}

\subsubsection{Sources and concentrations of PAHs}

Although air quality in Finland is typically good, PAH pollution is a problem in some areas. Sources of atmospheric PAH pollution and their influence on local air quality were studied in Virolahti (Paper V) and in the Helsinki Metropolitan Area (HMA) (Paper III).

Heating in the HMA is mainly based on an extensive district heating system that has only a minor impact on local air quality, and wood burning is the major heating system in only a small number $(2 \%)$ of district houses. However, the majority (90\%) of district houses use wood as a complementary heating method and as fuel for sauna stoves. Based on the measurements and modeling, wood combustion was found to be the main b(a)p source in the HMA (Paper III). Measured b(a)p concentrations correlated well with measured levoglucosan concentrations (levoglucosan is common wood burning marker, Simoneit et al. 1999), which supported this finding. It was also found that $b(a) p$ concentrations in the street environments were at the same level than at the urban background sites. Local traffic has a very small influence on b(a)p levels. The EU target value $\left(1 \mathrm{ngm}^{-3}\right)$ was clearly exceeded in some of the detached house areas in the HMA (Paper III). The proportion of $\mathrm{b}(\mathrm{a}) \mathrm{p}$ in $\mathrm{PM}_{2.5}$ mass was highest in district house areas, while in the street canyon, the ratio was close to urban and rural background areas. The amount of $b(a) p$ in $\mathrm{PM}_{2.5}$ mass varied between $0.01 \%, 0.003 \%$, and $0.001 \%$ in district house areas, street canyon/urban background/rural background, and remote background areas, respectively.

Due to enhanced fuel burning for energy, and especially due to increased biomass burning, including wood burning, elevated concentrations of $b(a) p$ and other PAHs are detected in wintertime. This was observed in Paper V, which found that daily mean PAH and b(a)p concentrations can vary widely (Figure 9). This is due to variable emission, sink, and weather situations. In the wintertime, when there are more emissions and less light, averaged weekly $\mathrm{b}(\mathrm{a}) \mathrm{p}$ and PAH concentrations measured at Virolahti were even 50 times higher compared to warm summer days. However, a similar trend was not seen in the simultaneously measured $\mathrm{PM}_{10}$ concentration time series. In the summertime, $\mathrm{PAH}$ emissions are lower, and degradation of PAH compounds is faster due to enhanced photochemistry (Lammel 2015, Ravindra et al. 2008). The annual average b(a)p concentration at Virolahti was reasonably high $\left(0.21 \mathrm{ngm}^{-3}\right)$ compared to other European background sites (Paper V). Only Kosetize in the Czech Republic and Rucava in Latvia had similar annual averages. Other European background sites were typically at the 10-75\% level compared to Virolahti. At remote station Zeppelin at Svalbard, the b(a)p level was very low, at 0.003 ngm $^{-3}$. 


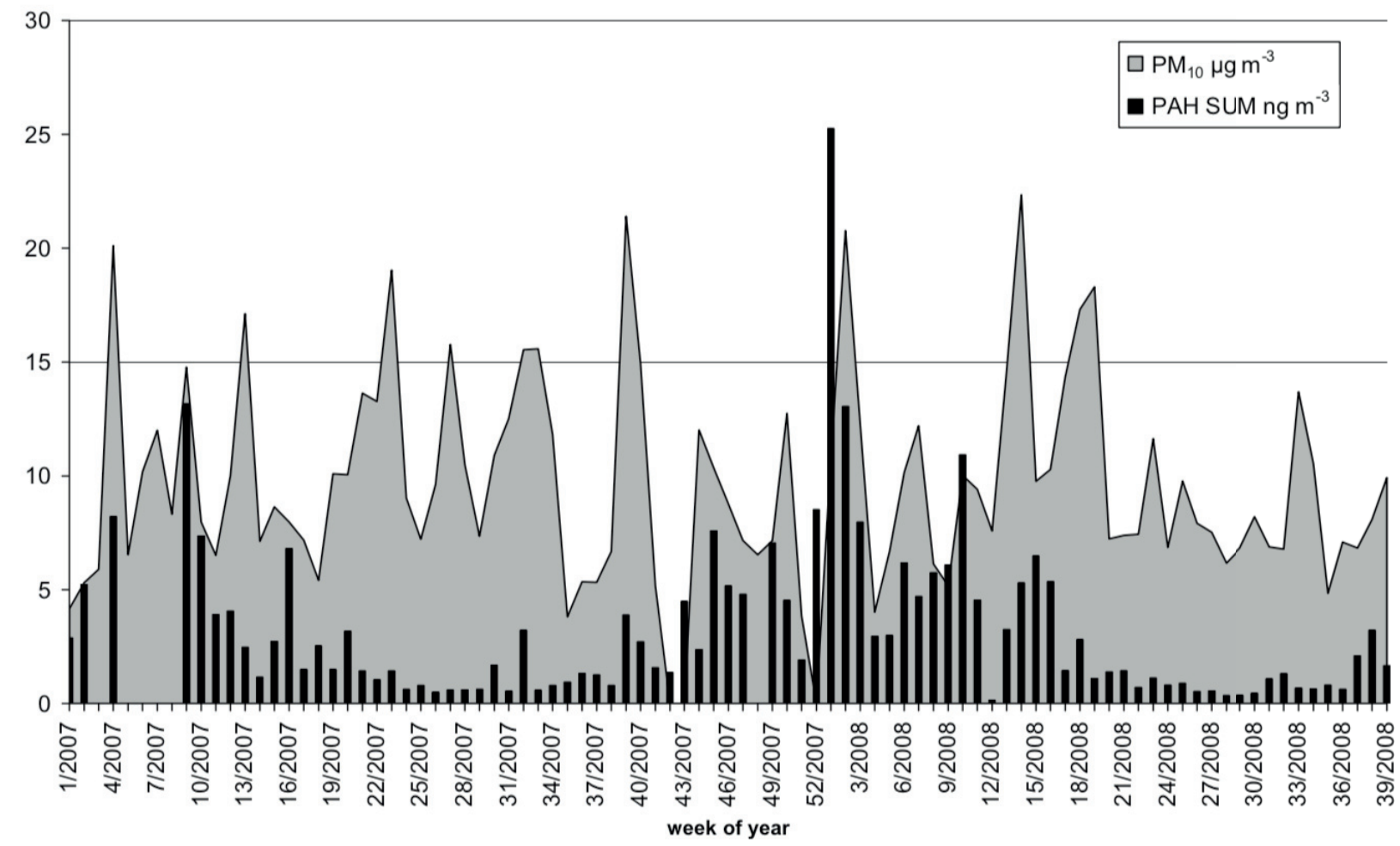

Figure 9. Weekly total PAH and $\mathrm{PM}_{10}$ concentrations measured at Virolahti between January 2007 and September 2008 (adapted from Paper V).

When analyzing the daily PAH dataset measured at Virolahti, Finland using PMF, the threefactor solution (from three- to seven-factor solutions) was the most reasonable and most interpretable. The three resolved factors were identified as soil and LRT, including secondary particles, combustion factor, and sea salt factor. Most of the measured PAH compounds came in the combustion factor that, according to wind analysis, originated from the southeastern side of the station. Also, most of the other measured burning emissions tracers such as $\mathrm{SO}_{2}, \mathrm{NO}_{\mathrm{x}}$, and black carbon, which are related to the emissions from fossil fuel combustion and traffic, entered this factor. Because the city of St. Petersburg, the largest city near the Gulf of Finland with its eight million inhabitants, is located in the same direction at a distance of $160 \mathrm{~km}$, it can be assumed that emissions from St. Petersburg traffic and energy production impact the air quality even in relatively remote areas from the city, such as Virolahti (Figure 10, Paper V). 

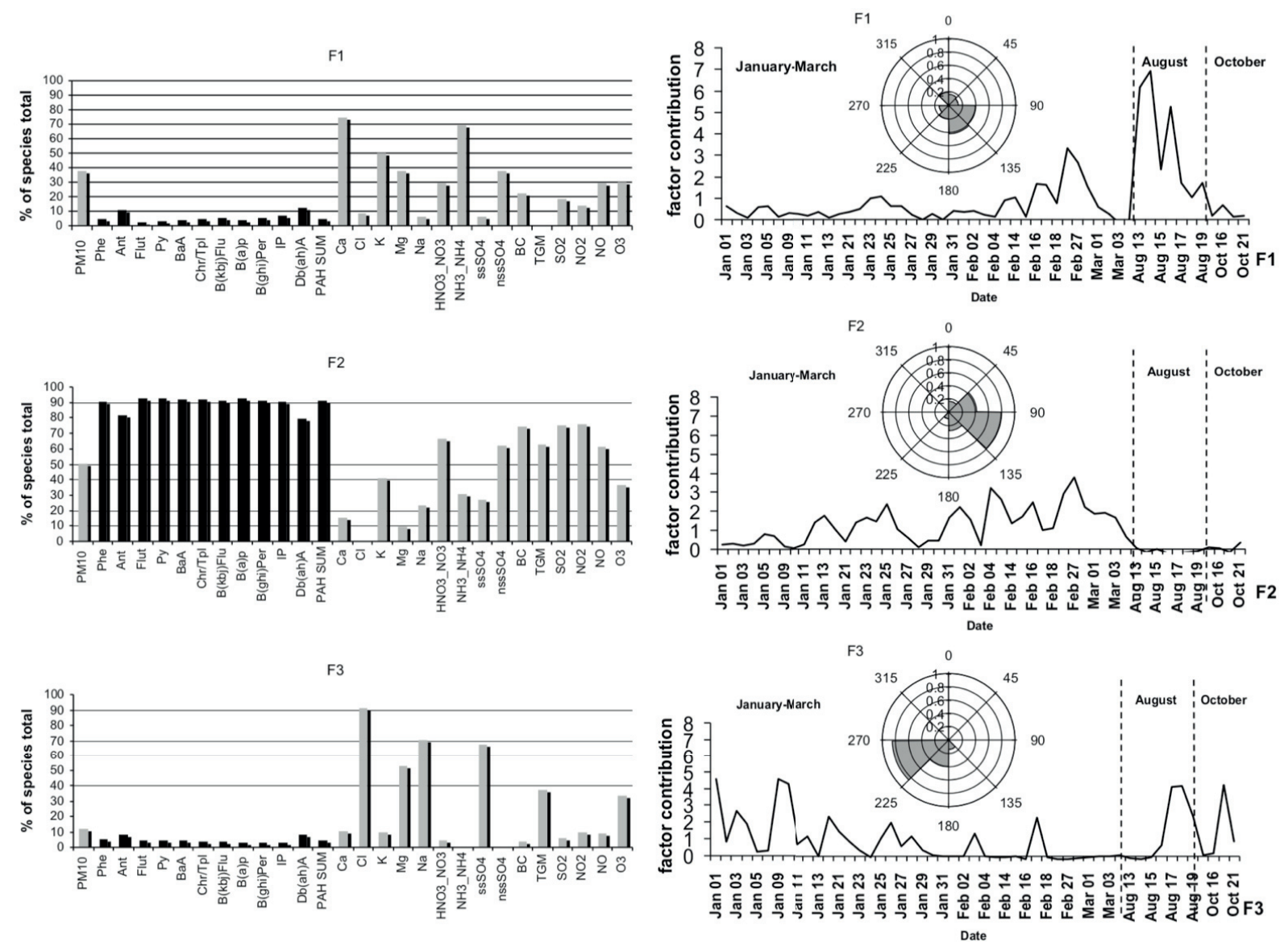

Figure 10. PMF factor compositions as a percentage of each component in each factor, factor contributions, and conditional probability function calculated for each factor using local surface wind data (Paper V). The resolved factors were long-range transport factor (F1), combustion factor (F2), and marine factor (F3) (adapted from Paper V).

\subsubsection{Sources of volatile organic compounds in the boreal forest}

PMF was used to resolve the sources of VOCs and their oxidation products in the boreal forest (Hyytiälä). Reactive systems, where concentrations change during transport from the emission source to the receptor, are challenging in receptor models. Because of the high reactivity of some biogenic VOCs, their emission profiles may change quite rapidly in the atmosphere on the way from the plant to the receptor site, when compared to primary emissions from a certain plant. It is important to understand that species concentrations and their relationships have been changed during the transportation from the source, and the apportioned source concentrations can vary. This was acknowledged in the interpretation of the model results of Paper I, in which volatile organic compounds and their oxidation product concentrations were measured in the boreal forest and their sources identified using PMF and CBPF.

In Paper I, the VOC dataset containing monoterpenes, sesquiterpenes, isoprene, 2-methyl-3buten-1-ol (MBO), methacrolein (MACR), C5-C10 aldehydes, benzene, and toluene, as well as the gases $\mathrm{CO}, \mathrm{NO}_{\mathrm{x}}$, and $\mathrm{O}_{3}$ measured at the same time at the SMEAR II station in Hyytiälä, was modeled. PMF found a reasonably interpretable solution with five biogenic and two 
anthropogenic VOC sources. Three other sources were more or less mixed biogenic/anthropogenic sources (Table 3).

Table 3. VOC factor classification, driver, main species, and source direction

\begin{tabular}{|c|c|c|c|c|c|}
\hline $\begin{array}{r}\text { Fac- } \\
\text { tor }\end{array}$ & Factor Name & Class & Driver & $\begin{array}{l}\text { Main species } \\
(\%)\end{array}$ & Source direction \\
\hline$F 1$ & Background & $\begin{array}{l}\text { Anthropogeni } \\
\text { c }\end{array}$ & $\begin{array}{l}\text { Backgroun } \\
\text { d }\end{array}$ & $\begin{array}{l}\mathrm{B}, \mathrm{T}, \mathrm{CO}, \mathrm{O}_{3}, \\
\mathrm{NO} \text {, aldehydes, } \\
\text { Bornyl acetate, } \\
\text { terpinolene }\end{array}$ & $\begin{array}{l}\text { south (Tampere), east } \\
\text { (Korkeakoski) }\end{array}$ \\
\hline$F 2$ & $\begin{array}{l}\text { Conifer emissions } \\
\text { LD }\end{array}$ & Biogenic & Light & $\begin{array}{l}\text { Isoprene, MBO, } \\
\text { 1.8-cineol }\end{array}$ & local \\
\hline$F 3$ & MACR & \multicolumn{2}{|l|}{$\begin{array}{l}\text { Biogenic/ } \\
\text { Anthropogenic }\end{array}$} & $\begin{array}{l}\text { MACR, } \\
\text { Isoprene, (T, } \mathrm{CO} \text {, } \\
\left.\mathrm{O}_{3}, \mathrm{NO}\right)\end{array}$ & local (station actions) \\
\hline F4 & Sawmill 1 & \multicolumn{2}{|l|}{$\begin{array}{l}\text { Biogenic/ } \\
\text { Anthropogenic }\end{array}$} & $\begin{array}{l}\text { Camphene, } \Delta 3- \\
\text { carene, } \mathrm{p} \text { - } \\
\text { cymene, } \\
\text { longicyclene }\end{array}$ & local, SE (sawmill) \\
\hline F5 & Pine TD & Biogenic & $\begin{array}{l}\text { Tempera- } \\
\text { ture }\end{array}$ & $\begin{array}{l}\alpha \text {-pinene, } \beta \text { - } \\
\text { pinene, } \Delta 3 \text { - } \\
\text { carene, myrcene }\end{array}$ & local \\
\hline F6 & Spruce LD & Biogenic & Light & $\begin{array}{l}\text { Isoprene, } \\
\text { aldehydes, } \beta \text { - } \\
\text { farmesene }\end{array}$ & SE \\
\hline$F 7$ & Sawmill 2 & \multicolumn{2}{|c|}{ Biogenic/Anthropogenic } & $\begin{array}{l}\text { p-cymene, } \beta \text { - } \\
\text { pinene }\end{array}$ & W, SE, local \\
\hline F8 & Spruce TD & Biogenic & $\begin{array}{l}\text { Tempera- } \\
\text { ture }\end{array}$ & $\begin{array}{l}\text { Limonene, } \\
\text { terpinolene, } \\
\text { myrcene, b- } \\
\text { caryophyllene, } \beta- \\
\text { farmesene }\end{array}$ & local \\
\hline F9 & Heating & $\begin{array}{l}\text { Anthropogeni } \\
\text { c }\end{array}$ & $\begin{array}{l}\text { Tempera- } \\
\text { ture }\end{array}$ & $\mathrm{B}, \mathrm{T}, \mathrm{CO}, \mathrm{NO}_{\mathrm{x}}$ & SE (Korkeakoski) \\
\hline F10 & Photochemistry & Biogenic & Light & $\begin{array}{l}\text { Nopinone, } \beta- \\
\text { farmesene, } \\
\text { MBO, 4-ACMH }\end{array}$ & local \\
\hline
\end{tabular}

Ten separate VOC sources were resolved, five of which were biogenic originated: Conifer emissions (F2), Pine, (F5), light-driven Spruce emissions (F6), temperature-driven Spruce emissions (F8) and Photochemistry (F10). Two anthropogenic sources, Background source (F1), and Heating (F9) were resolved. Three sources that were interpreted as mixed biogenic/anthropogenic sources were an MACR source (F3) and two Sawmill sources (F4 and F7). MACR is an isoprene oxidation product but is also emitted from traffic (Reimann et al. 2000, Borbon et al. 2001). The sawmill source typically emits biogenic-originated VOCs from different tree species, but sawmill operations can also emit typical anthropogenic-originated pollution, such as $\mathrm{NO}_{\mathrm{x}}$ and $\mathrm{CO}$ from fuel burning and $\mathrm{CO}$ from the auto-oxidation of unsaturated carbonyl compounds in, e.g., wood pellets, chips, and sawdust piles (Rahman and Hopke 2016, Blomqvist et al. 2007). Resolved source contributions to certain VOC groups are presented in Figure 11. 
The main monoterpene source was found to be temperature-dependent emissions from Scots Pine (F5). This important pine source contributed to half (53\%) of the total measured monoterpene mass. Monoterpene contributions from other sources were related to the Korkeakoski sawmill emissions (13\% of total monoterpenes), temperature-dependent emissions from spruce, and photochemical activity source.

The main sources of sesquiterpenes ( $\alpha$ - and $\beta$-farnesene and $\beta$-caryophyllene) are expected to be very local because of their short lifetimes due to high reactivity. Temperature-dependent spruce and pine emissions were found to be the major biogenic sesquiterpene sources. The contribution of these temperature-dependent sesquiterpene sources were highest in July. In Paper III, the concentration of measured caryophyllinic acid, which is the oxidation product of ß-caryophyllene, was also peaking in July, so these results are in good agreement. The contributions of these sources were highest in early morning and in the evening. This is in convergence with Barreira et al. (2021), who also detected a sesquiterpene burst in the early morning in spring in the boreal forest. Effective dilution and increasing sink reactions into the aerosol phase then rapidly decrease sesquiterpene concentrations, leading from a morning maximum to daytime minima. They also found that even the measured sesquiterpene concentrations in ambient air were relatively low; sesquiterpenes were an important contributor in the aerosol phase. Anthropogenic sesquiterpene sources were sawmill factors with a minor contribution, $16 \%$ of measured sesquiterpenes.

Aldehydes can be directly emitted or produced in chemical reactions. The light-dependent spruce source was the major $\mathrm{C} 6-\mathrm{C} 10$ aldehyde source, with $65 \%$ contribution. Also, the background source had a minor contribution (11\%). Concentrations for this source came mainly from the southern side, but the highest contributions for F6 came at moderate wind speeds from the sawmill and Korkeakoski directions.

Local anthropogenic heating emissions and background concentrations were the major sources for benzene and toluene in Hyytiälä. These were quite clear anthropogenic sources; most CO and $\mathrm{NO}_{\mathrm{x}}$ also came within these two factors and in the MACR factor, which states the existence of anthropogenic-related MACR emissions, in addition to being an isoprene reaction product.

A local light-driven conifer emission source and photochemistry source were the factors that mostly correlated to $\mathrm{PM}_{2.5}$ aerosol total volume $\left(\mathrm{R}_{2}=0.58\right.$ and 0.61 , respectively). This was expected, as monoterpene oxidation results are believed to be a major contributor of SOA growth in the boreal forest (Kiendler-Scharr et al. 2009). Most nopinone, which is an ß-pinene oxidation product, was also apportioned to the photochemistry factor. However, the main part of the biogenic VOC mass in the photochemistry source came from $\alpha$-pinene $(60 \%)$ and $\Delta 3$ carene $(21 \%)$. 

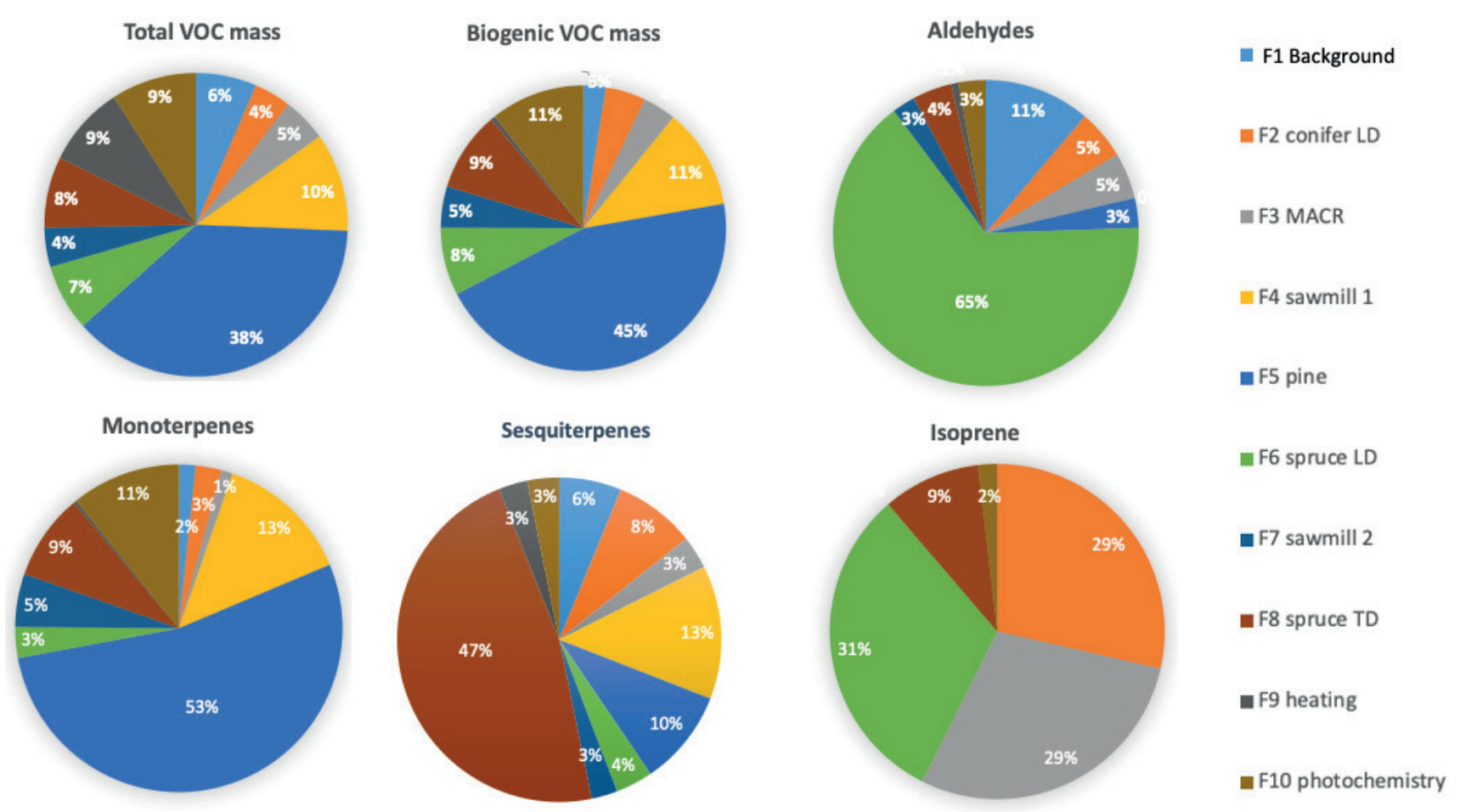

Figure 11. Contributions of resolved PMF factors to VOC concentrations.

\subsubsection{Biogenic acids in aerosol in the boreal forest}

In Paper IV, organic acids that are reaction products of certain terpenes and sesquiterpenes were measured from fine aerosol in the boreal forest in Hyytiälä. The concentrations of these organic acids were found to be highest in summer, as the light- or temperature-dependent emissions of their precursors are also high then (Figure 12). In Paper I, pine was found to be the main source of $\alpha$ - and $\beta$-pinenes, which are pinonic acid precursors, and the temperature-dependent pine factor contribution was clearly peaking in July. However, there were also measurable concentrations in winter, when there should not be biogenic emissions of these compounds, at least not significant ones. The highest measured concentration of pinonic acid occurred in February. In Paper I, 9\% of $\alpha$-pinene and $15 \%$ of $\beta$-pinene concentrations were apportioned to the sawmill factors, and these terpene emissions from sawmill operations probably produce aerosol more effectively in winter compared to summer as temperatures are lower then. VOC emissions that originate biogenically in the warm season are mainly of anthropogenic origin during wintertime, when wood is used in industry.

$\beta$-caryophyllinic acid concentrations were higher than expected based on emission calculations (e.g., Tarvainen 2007). This suggests that $\beta$-caryophyllene emissions from the boreal forest were underestimated and supports Hellén et al.'s (2018) finding that sesquiterpenes greatly impact ozone chemistry in the boreal forest, which also indicated that sesquiterpenes have an important role in local SOA production. Hellén et al. (2021) also showed that temperature- 
dependent emissions of sesquiterpenes and oxygenated sesquiterpenes from downy birch were dominating among the species emitted at the beginning of the growing season.
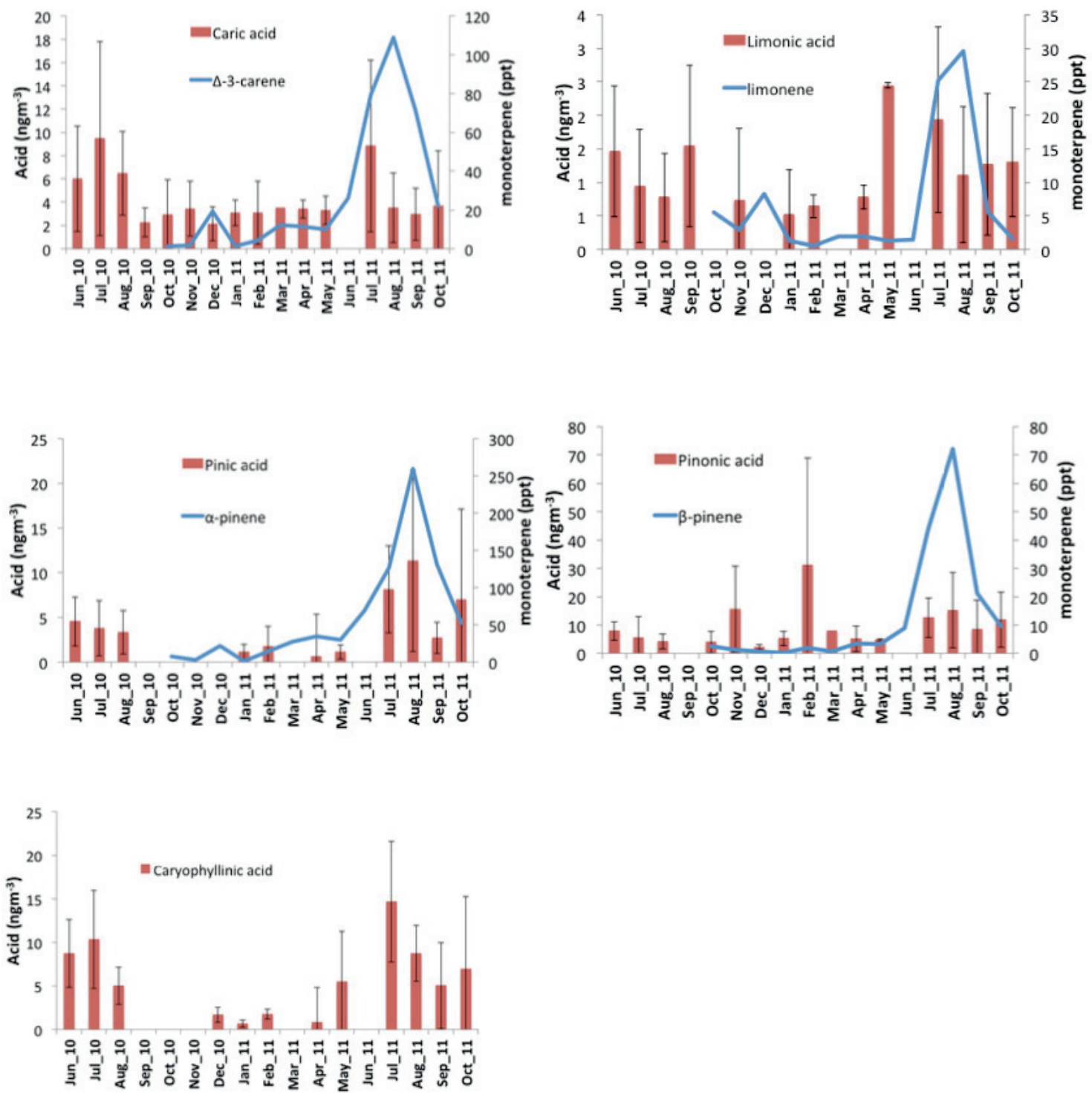

Figure 12. Concentrations of selected biogenic acids and their parent monoterpene concentrations measured in the boreal forest. The figure is adapted from Paper IV.

Sesquiterpene emissions from the boreal forest are probably underestimated. Considering their higher reactivity with the ozone and relatively high aerosol yield when comparing to monoterpenes, sesquiterpene oxidation products, e.g., oxygenated sesquiterpenes and acids, probably have a more important role in SOA production than previously estimated (e.g., Griffin et al. 1999, Lee et al. 2006, Hellén et al. 2018, Hellén et al. 2021). 


\subsection{Aerosol composition at Pallas}

\subsubsection{Sources of trace elements}

Source apportionment of trace elements at Pallas were studied using PMF in Paper II.For the Pallas PM data, source apportionment was done for two time series: the full dataset of 19962018 and the recent years, 2014-2018. These periods were chosen to represent the overall source categories since the beginning of the measurements and the more recent source contributions in the 2010s. Here, the analysis results of the full dataset are discussed. The PMF analysis was run with four to seven factors. The five-factor solution was adopted as it produced a good fit to the data and was most reasonable to interpret. The factor contributions are presented in Figure 13 for the 1996-2018 dataset.

\section{Pallas HM-SA 1996-2018}

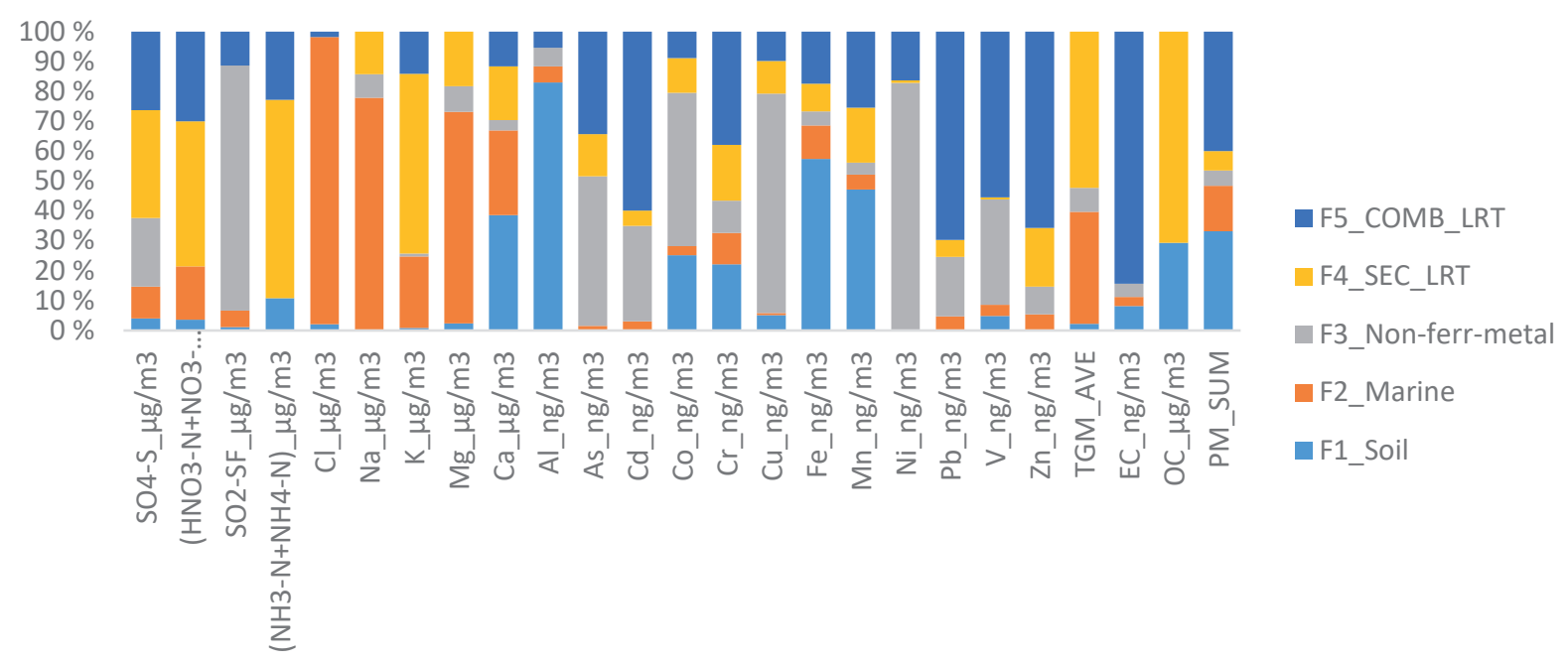

Figure 13. Results of the source apportionment for Pallas during 1996-2018. The factor compositions are presented as a percentage of each component in each factor.

The sources in this selected five-factor solution were soil (F1), marine aerosol (F2), non-ferrous metal smelting (F3), long-range transported secondary LRT aerosol (F4), and long-range combustion aerosol (F5). The first factor (F1) was related to soil re-suspension as a big portion of the measured soil crustal elements $\mathrm{Al}$ and $\mathrm{Fe}$ of $\mathrm{Mn}$ and $\mathrm{Ca}$ masses was apportioned in this source. This factor shows strong seasonality with summer peaks. OC in this source was interpreted as a biogenic source associated with this factor. This biogenic local source showing summertime peaking is most likely VOC emissions from the vegetation in the summertime. VOCs are oxidized rapidly in the atmosphere, and their reaction products contribute to aerosol formation and growth, as discussed in Papers I and IV, and, e.g., in Hellén et al. (2018) and Tunved et al. (2006). 
The second factor (F2) was clear marine factor with high loadings $\mathrm{Na}, \mathrm{Cl}$, and $\mathrm{Mg}$. This source represents relatively clean airmasses from the Arctic Ocean (Figure 13). The time series for this factor, similar to F1, showed relatively clear summertime peaking. Also, approximately onethird of TGM came in this factor, suggesting that the sea is an important single source of gaseous mercury; this was also noted in Paper V, which also reported part of TGM relating to the sea salt factor in the data measured at the coastal Virolahti site. However, the major source of TGM came mainly in the long-range secondary aerosol source from farther south (F4), and a small part of it also came in the non-ferrous metal smelting factor (F3) originating from the eastern direction from the station. The potential source contribution function for these sources based on trajectory data is shown in Figure 14.
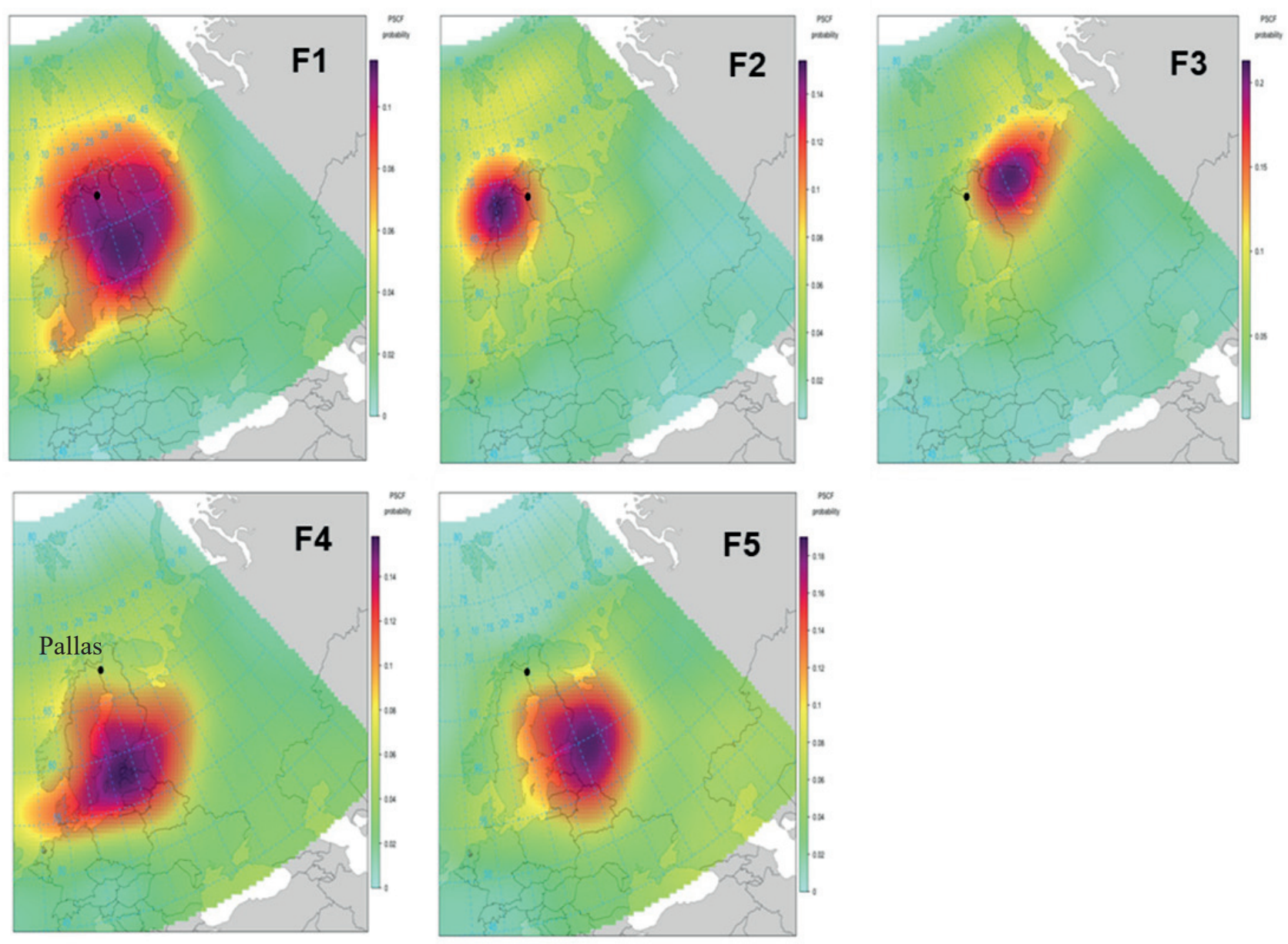

Figure 14. Potential source contribution function pictures of the five-factor PMF solution for Pallas $\mathrm{PM}_{10}$ aerosol in the years 1996-2018. These pictures present soil (F1), marine (F2), nonferrous metal smelting (F3), secondary LRT (F4), and combustion LRT (F5). The concentration scales differ. The figure is adapted from Paper II and Kyllönen (2020).

The third factor was named non-ferrous metal smelting, with a relatively high portion of $\mathrm{Ni}$, $\mathrm{Cu}$, As, and Co. Also, most $\mathrm{SO}_{2}$ and $23 \%$ of $\mathrm{SO}_{4}$ were seen in this factor. A high proportion of $\mathrm{SO}_{2}$ in this factor refers to a relatively close $\mathrm{SO}_{2}$ source. According to PSCF analysis, element composition in the factor and literature sources (e.g., Paatero et al. 2008, Timonen et al. 2018, 
Virkkula et al. 1999) represents the emission source of the Ni-Cu smelters in the Kola Peninsula and was named non-ferrous metal smelting.

The fourth factor (F4) was interpreted as a secondary LRT factor with high loadings of $\mathrm{NH}_{4}$, $\mathrm{NO}_{3}$, and $\mathrm{SO}_{4}$, referring to aged, polluted air masses where $\mathrm{SO}_{2}$ and $\mathrm{NO}_{\mathbf{x}}$ have been neutralized by $\mathrm{NH}_{3}$ to form $\mathrm{SO}_{4}$ and $\mathrm{NO}_{3}$. Additionally, high portions of $\mathrm{OC}, \mathrm{TGM}$, and $\mathrm{K}$ were apportioned to this source. TGM is typically attributed to LRT due to its long lifetime in the atmosphere (Durnford et al. 2010). OC can also be attributed to LRT, among other sources, in the Arctic (Schneidemesser et al. 2009, Timonen et al. 2018). K is often used as a tracer for biomass burning, but it also has several other sources related to, e.g., LRT (Pachon et al. 2013). The PSCF analysis for this factor suggests that sources mostly associated to the southern direction from Pallas, including a larger area in southern Finland and Eastern Europe.

The fifth factor (F5) included a major part of several trace elements, suggesting anthropogenic sources. Most of the total measured $\mathrm{Pb}, \mathrm{Zn}, \mathrm{Cd}, \mathrm{V}$, and approximately one-third of $\mathrm{Cr}$ and $\mathrm{As}$, were apportioned in this factor. Most elemental carbon (EC) is also found in this factor. Of the Finnish anthropogenic emissions of these elements, 70-90\% are emitted from energy production (Kyllönen 2020, SYKE 2021). In Europe, As, Cd, and Pb mainly originate from energy production, distribution, and use in industry, while for black carbon, there are several reported sources, including commercial, institutional, and household road transport and energy (EEA 2019a, EEA 2019b, Kyllönen 2020). Fuel combustion and biomass burning are also known as important EC sources in the Arctic (Bond et al. 2004, Hyvärinen et al. 2011, Sharma et al. 2013, Winiger et al. 2016). Using PSCF analysis, the source region for this factor was traced to Eastern Europe and also to Southern Finland. This is similar to Hyvärinen et al. (2011), where $\mathrm{BC}$ was found to mostly originate from Central and Eastern Europe, while moderate source areas are located in Southern Finland. Therefore, this factor was interpreted as an LRT combustion source (Kyllönen 2020).

In summary, five main sources were found in Pallas 23-year trace element dataset. The sources included soil (F1), marine aerosol (F2), non-ferrous metal smelting (F3), long-range transported secondary LRT aerosol (F4), and combustion aerosol (F5). The highest amount of trace metal pollution of $\mathrm{Ni}, \mathrm{Cu}, \mathrm{As}, \mathrm{Co}$, and $\mathrm{SO}_{2}$ originated from the Kola Peninsula. This was expected, as there is a lot of metal industry in the Kola Peninsula area. However, as Norilsk Nickel closed its metallurgical operations at Monchegorsk, Kola Peninsula in March 2021, the trace element and $\mathrm{SO}_{2}$ emissions from the area should be declining in the future (Nornickel 2021). The main source of $\mathrm{Pb}, \mathrm{Zn}$, and $\mathrm{Cd}$ at Pallas, which are air pollution traces from energy production, were apportioned to Eastern Europe, including Southern Finland.

\subsubsection{Sources of POP compounds}

Sources of persistent organic pollutants measured in 1996-2018 at Pallas were investigated for this work. These compounds are considered priority pollutants, and their use and production are banned or regulated through international agreements, e.g., in the Stockholm Convention on Persistent Organic Pollutants and in the Aarhus protocol on POPs under the Convention on 
Long-range Transboundary Air Pollution (CLRTAP) (UNEP 2019, UNECE 1998). Measured POP compounds and total beta radioactivity data were incorporated into the trace elements dataset (Paper II), and a new source apportionment study was conducted. These unpublished data on POPs were included in this thesis to support results on trace metals in Paper II and to provide interesting new results on POP sources in the Arctic. Currently, most of the POP compounds measured from aerosols at Arctic sites have shown decreasing trends (e.g., Anttila et al. 2016). However, the concentrations of some of those compounds like $\alpha-\mathrm{HCH}$ and HCB have not been decreased, and it has been suggested that this is due to global warming. Arctic waters and melting ice have turned from sink to sources that slowly release these compounds into the atmosphere (e.g., Wöhrnschimmel et al. 2012, Bidleman et al. 2015, Hung et al. 2016, Wong et al. 2021). This is quite an interesting suggestion, and this source apportionment result for the origin of the POPs measured at Pallas between 1996 and 2018 presented here further support the finding that there is a source of POPs in the direction of the North Sea, in an otherwise relatively clean area where any significant primary sources should not exist.

The Swedish Environmental Institute (IVL) has measured POPs at Pallas since 1996 (e.g., Anttila et al. 2016). This IVL POPs dataset, first measured during the first week of each month, and later weekly, and was combined with the trace metal and ion $\mathrm{PM}_{10}$ dataset previously introduced in Paper II; PMF source apportionment was made for this combined dataset (Figure 15). A total of 1025 weekly samples were combined in this dataset. It is notable that the collection time for these samples is relatively long, and ambient weather conditions, including wind direction, can considerably vary during the week. This leads to source mixing, which should be considered when interpreting results. However, a relatively high number of samples helped statistically, and in trajectory analysis, several trajectories per day were selected through each sampling period, which also enhanced the trajectory statistics. As expected, rather similar sources were found, as in Paper II, but the interesting point here is where the POPs are coming from. The source areas for these PMF-resolved factors for the combined POP dataset are presented in Figure 16. IVL POP data are used with permission. 

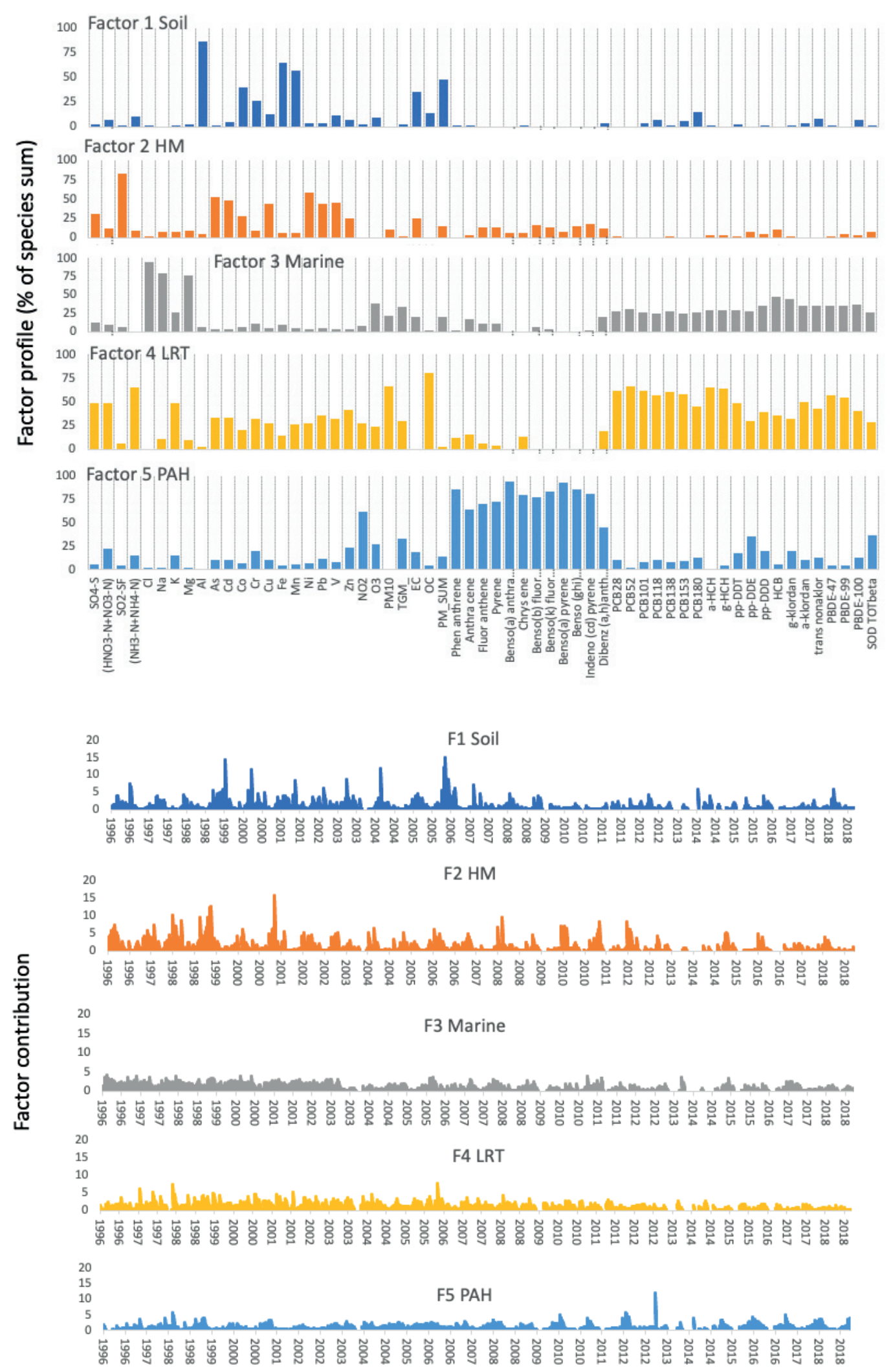

Figure 15. PMF source apportionment of combined POP datasets measured at Pallas, 19962018. Source profiles (percentage of species sum in each factor) are on top and source contributions (factor time series) below. POP compounds are on the right side of the profile picture (starting from PCBs). 
Several different factor combinations were investigated. As in Paper II, the five-factor combination was selected. The selected model result was reasonable to interpret, and quality checks using bootstrap and displacement error evaluation methods showed valid results. In the chosen model result, soil, heavy metal, marine, LRT, and PAH sources were found. Soil, marine, and heavy metal sources were still quite similar to the results in Paper II. This was expected and good, as it further validated this result. However, as most PAHs seemed to make their own combustion-related factors, and some heavy metals previously in the burning factor, e.g., $\mathrm{Cd}$ and $\mathrm{Pb}$, were now apportioned to the LRT factor. The POPs' fates were more closely examined in this modeling exercise.
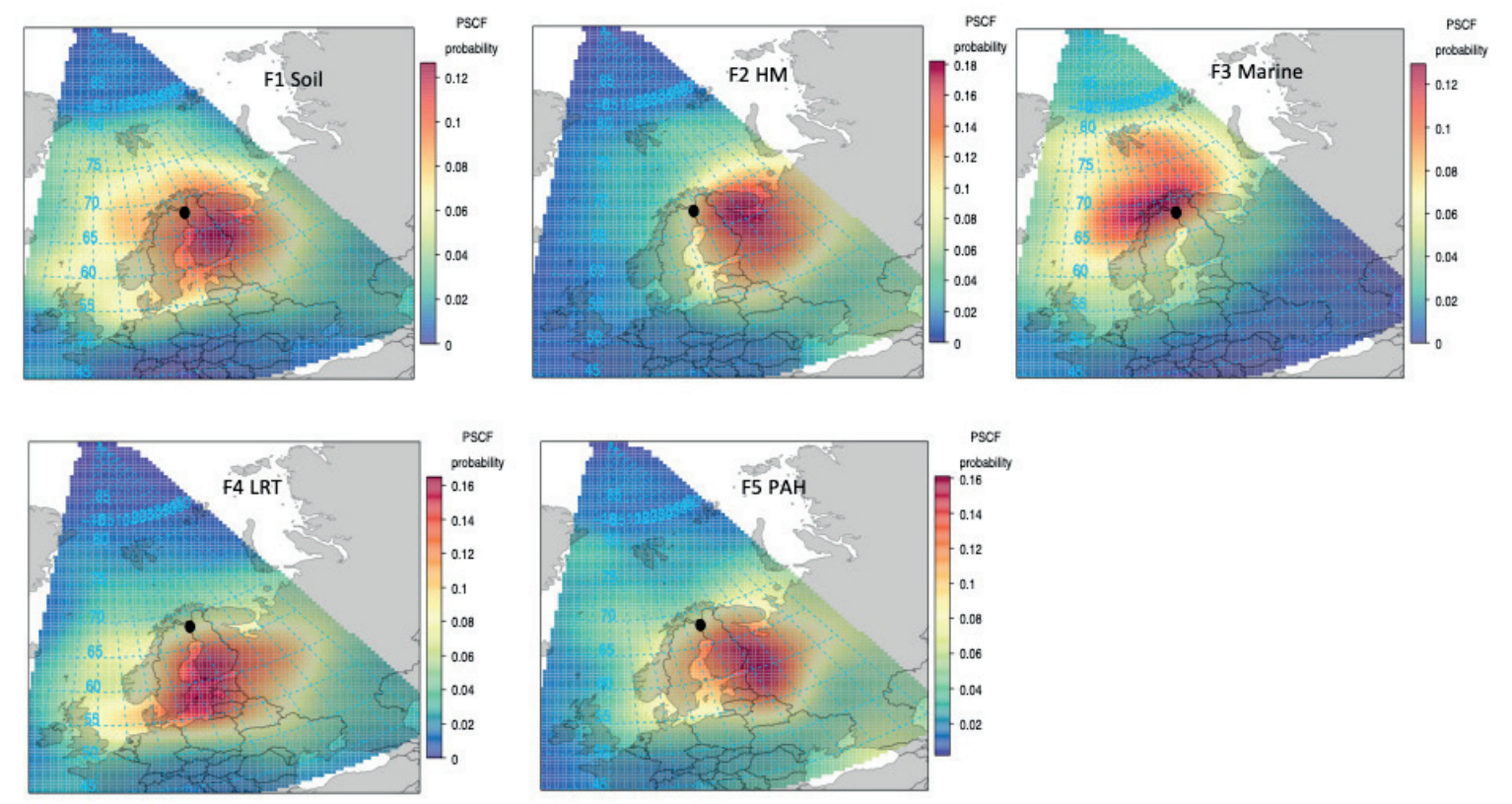

Figure 16. Potential source contribution pictures for each resolved factor for the POP dataset. Areas in red indicate the higher probability source areas for each factor. Factors are F1 Soil, F2 Heavy metals, F3 Marine, F4 LRT, and F5 PAH.

As previously mentioned, the main part of PAHs measured at Pallas went to the burningoriginated factor named the PAH source (Figure 15). A minority of PAHs was also apportioned into LRT, marine, and heavy metal factors. However, PAH species' contribution to factors other than PAHs were low, at less than 20\%. According to the PSCF picture made using NOAA air mass trajectories, it was found that the main PAH source for Pallas (F5) originated from domestic Finland (Figure 16). As time series for this factor show that this source is peaking mostly in wintertime and is lower during warmer summer periods, it is likely that this factor describes the combustion source including domestic heating in Finland, which also includes PAH emissions from fossil fuel and biomass burning. However, only $16 \%$ of potassium $(\mathrm{K})$, which is often interpreted as a biomass burning marker, came within this PAH factor, as half of it went to the LRT factor and 25\% to the marine factor, as in the heavy metal PMF analysis in Paper II. A small amount of $\mathrm{SO}_{2}, \mathrm{SO}_{4}$, and PAHs also came in the marine factor. When marine aerosols come from the north to the measuring site, they 
collect pollution alongside their route over the land. This explains that there are pollution traces like $\mathrm{SO}_{2}, \mathrm{SO}_{4}$ and some PAHs, from e.g., ships, as well as traces of wood burning mixed in this relatively clean marine factor. LRT from Southern Finland and Eastern Europe also contains traces of wood burning, as there is a lot of wood burning in Finland and other countries in Eastern Europe.

POPs were mainly split into two factors. The first one here is LRT (F4) (Figure 15); according to the PSCF picture, this was interpreted as a long-range transport-related factor, as air masses in this factor originated from Southern Finland, Mid-Eastern Europe, and Western Russia. A similar factor was called secondary LRT source in Paper II. The main part of POPs went into this factor. Around $60 \%$ (45-67\%) of PCBs, $65 \%$ of HCHs, $48 \%$ of DDT, $40 \%$ and $30 \%$ of its degradation products DDD and DDE, and $40-60 \%$ of flame retardants, PBDEs, also came within this factor.

One-third of DDE and around 20\% of DDT and DDD came with the PAH factor. This is in line with Ubl et al.'s (2012) finding that Western Russia was the most important primary source of the three PCB congeners (PCB-28, 101, and 280) measured in Arctic stations Zeppelin and Alert. Those POP compounds have been extensively used in the past, as e.g., insecticides and fungicides, and they are still attached to, e.g., soil components and emitted into the air from those areas.

The rest of the POPs, interestingly, were incorporated in the air masses that came within a marine source, which, according to the PSCF pictures drawn from the trajectory data, mainly originated from the northern side of the Pallas station, over the North Sea, and over the northern coastlines of Norway and Russia (marine source in Figure 15). This marine source included clear marine markers $\mathrm{Na}, \mathrm{Cl}$, and $\mathrm{Mg}$, and a small portion of burning markers like, e.g., sulphates, $\mathrm{PAH}, \mathrm{NO}_{2}$, or EC. Interestingly, it also included $39 \%$ of the measured ozone. However, a relatively big portion of measured POPs came with this source, i.e., approximately half (48\% and $45 \%$ ) of organochloride compounds HCB and $\alpha$-chlordane and about one-third of PCBs and PBDEs. These compounds are persisted organic compounds with long degradation times in the environment. There should not be any remarkable anthropogenic sources of these POPs in the North Sea. So, it can be assumed that the compounds in this source are those that have previously accumulated into arctic areas within air masses or sea currents from more polluted areas and are now slowly released back into the atmosphere due to melting of the arctic areas. This was already noted for a-HCH by Wöhrnschimmel et al. (2012), Bidleman et al. (2015), and most recently by Wong et al. (2021).

The last species on the right side of the model (SOD-totbeta) is total b-radioactivity (total beta activity) concentration measured at Sodankylä, which was included in the dataset as the continental air marker. This total beta activity concentration consists mainly of lead-210 (Pb210 ) and its decay product bismuth-210 (Bi-210). Lead-210 is formed in the atmosphere from the radioactive decay of radon-222 (Rn-222) diffusing from the soil into the atmosphere. Oceans are a negligible source of airborne radon-222. Therefore, radon-222 and its daughter 
nuclides are tracers for air masses with a recent contact with land areas (Baskaran 2011, Paatero and Hatakka 1997). In this exercise, the main part of total beta activity, $36 \%$ and $29 \%$, came with PAH and LRT sources, as these sources are mainly continental. These continental air masses also partly came over the Baltic Sea. Additionally, 26\% of the measured total beta activity came in the marine factor, suggesting either somehow mixed factor or it can be an underestimation of uncertainties of total beta activity concentration. However, the marine factor looks quite solid otherwise, and modeled total beta activity for mainly continental-originated PAH and LRT sources is reasonable. A sum of the selected species group in Pallas POPs source apportionment is presented in Figure 17.

Pallas POPs 1996-2018

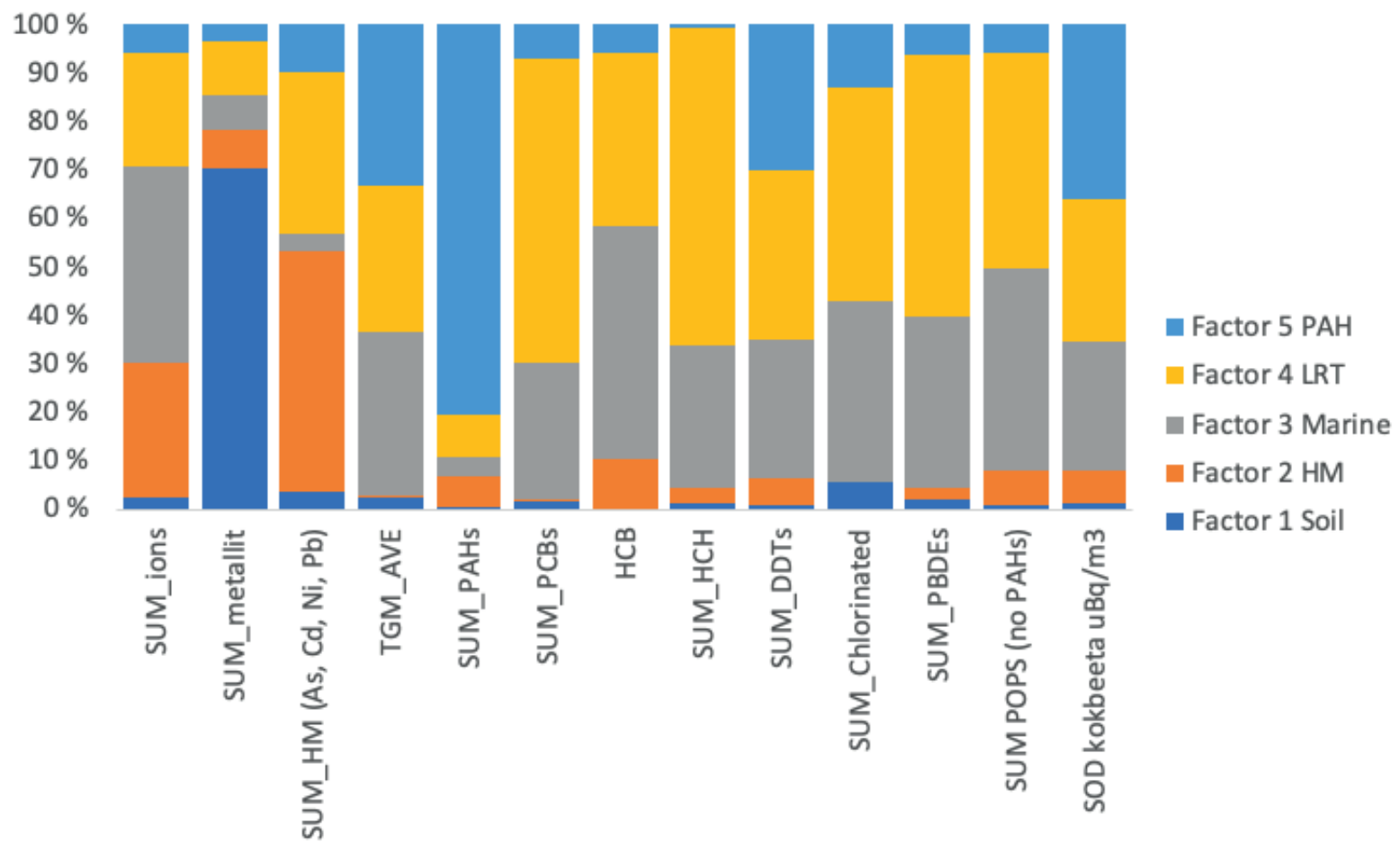

Figure 17. Results of the source apportionment for the Pallas POP study during 1996-2018. Factor compositions are presented as a percentage of each component/compound group in each factor. Columns present the sums of each component group, except hexachlorobenzene (HCB), total gaseous mercury (TGM), and total beta activity measured from Sodankylä highvolume filter samples (SOD kokbeeta), which are single species.

POP compounds measured at Pallas in 1996-2018 were mainly split into three main sources (Figure 17). A relatively big portion of measured POPs came from a marine source from clean areas from the northern side of the Pallas station and from the Northern Sea, where there should be no distinctive POPs sources except for secondary emissions from melting ice and water. These data need further investigation. 


\section{REVIEW OF PAPERS AND AUTHOR'S CONTRIBUTION}

In Paper I, PMF was used for the first time, according to our knowledge, to resolve biogenic VOC emissions from single sources in the boreal forest. In earlier studies, VOC sources resolved using source apportionment methods have been classified commonly as "industry" or "biogenic," but biogenic sources have not been specified in greater detail. In this work, we studied several different biogenic VOC sources inside a "common" biogenic VOC source group. PMF was applied to VOC concentrations measured in the boreal forest at Hyytiälä, Finland to resolve the species emissions that affected the observed ambient reactive VOC concentrations. We showed that PMF can also be used to resolve the sources in quasistationary systems, such as ambient VOCs, in the boreal forest. My co-authors measured and validated the dataset used in this study. I validated the dataset for the model, performed source apportionment, validated and interpreted the first model results, performed CBPF calculations for the model result and wrote the modeling part; the final source apportionment result was interpreted in co-operation with the co-author. The writing process was then continued in cooperation with my colleagues. The modeling work and beginning of the writing process was made under the supervision of Prof. Philip K. Hopke at the University of Rochester, NY, USA.

Paper II is based on the monitoring and source apportionment of atmospheric heavy metals in PM at a sub-arctic Pallas site. In the article, data from 1996-2018 were analyzed for spatial and temporal trends, and source apportionment was made with PMF. I validated the data for PMF modeling, made the source apportionment, interpreted the PMF results, and wrote the source apportionment part of the article. I also calculated trajectory modeling (PSCF) results for each factor, commented on the rest of the article, and took part of the validation of the supplementary data for the article.

In Paper III, the impact of wood burning on b(a)p concentrations in Helsinki was estimated using measurements and modeling. It was found that that biomass burning, especially smallscale wood burning, is the main local b(a)p source in the Helsinki Metropolitan Area. B(a)p concentration correlated well with the wood burning marker levoglucosan in daily and monthly means, and b(a)p concentrations were clearly higher in the suburban one-family house areas compared to, e.g., street canyons in the city. I took part in collecting data from the databases, analyzed part of the PAH samples used in this study, took part in the data analysis, wrote the PAH experimental part, and assisted in writing the article.

Paper IV was about the concentration of biogenic acids in the fine aerosol of the boreal forest at Hyytiälä, Finland. It was found that even though the five measured terpenoid acids were found to contribute to only a small fraction of aerosol or organic carbon mass, $0.3-0.7 \%$ and $1-3 \%$, respectively, they participate in the particle growth process in the boreal forest, which is important in the formation of cloud condensation nuclei. I built the sampler and set up the 
aerosol collection on site, developed the analyzing method together with my colleagues, analyzed the samples, validated the data, and analyzed the time series; I also participated in interpreting the results and writing with my colleagues.

In Paper V, sources of PAH pollution in $\mathrm{PM}_{10}$ aerosol at Virolahti were estimated using daily and weekly $\mathrm{PM}_{10}$ samples from 2007 to 2008, together with ion and gas data. In the background area of Virolahti, Eastern Finland, it was found that most PAH pollution came from the east, from the direction of St. Petersburg. This was my first paper and the first PMF paper in which I was involved. I analyzed the PAH samples, constructed the modeling datasets and time series from existing PM and gas data measured at Virolahti, analyzed the data, made the PMF analysis, interpreted the results, and wrote the article with my colleagues. 


\section{SUMMARY AND IMPLICATIONS}

\subsection{Summary}

Air pollution is an important global risk to human health and ecosystems in the world. Particulate matter has an important role in air pollution and climate change and also a great effect on air quality. The danger of particulate matter in air occurs due to the particle size and the chemical compounds they contain. In this work, sources and concentrations of selected chemical compounds in atmospheric aerosol were studied. Time series from polycyclic aromatic hydrocarbons (PAH) and biogenic organic acids in aerosol were measured, and their effect on local air quality was estimated. The sources of PAHs, trace elements, biogenic volatile organic compounds, and persistent organic compounds (POPs) were resolved using positive matrix factorization (PMF).

PAH emissions to the air are problematic, especially in Eastern Europe, as the annual EU target value of PAHs in $\mathrm{PM}_{10}$ aerosol is commonly exceeded in many countries. However, as there are many small towns and municipalities in Finland where wood burning is very common, thus target value exceedances for $b(a) p$ are probably also quite common in Finland. However, this has not been proven using the measurements, as PAH measurements are quite scarce in Finland. PAHs are toxic substances and pose substantial health risks to people living in areas with exceedances. Because PAHs originate from burning, especially from wood burning, their emissions will likely not decrease in the near future.

PAHs were measured at the Virolahti background station in Southeastern Finland. Measured average $b(a) p$ concentrations were low, between 0.03 and $1.67 \mathrm{ngm}^{-3}$, with a yearly average of $0.23 \mathrm{ngm}^{-3}$, which is well below the annual target value of $1 \mathrm{ngm}^{-3}$. However, the measured b(a)p concentration at Virolahti was relatively high compared to other European background stations, which may indicate the effect of St. Petersburg, which is a major megacity within 160 $\mathrm{km}$. Source apportionment of Virolahti data showed that the majority of PAHs came in the combustion factor with most other combustion markers from the eastern sector, from the direction of St. Petersburg. Also, traces of wood burning came in this long-range transport factor. High loadings of $\mathrm{SO}_{2}$ and $\mathrm{NO}_{\mathrm{x}}$ in this factor may indicate that it is a mixed source, including traffic, energy production, and biomass burning.

Based on the measurements made in the Helsinki Metropolitan Area (HMA) by the Helsinki Environmental Authority (HSY), traffic was found to be only a minor contributor to $b(a) p$ in HMA, while biomass burning, which is mainly wood burning in detached house areas, has a major impact on $b(a) p$ concentrations there. This was further proved with a good correlation between measured wood burning marker levoglucosan and b(a)p concentrations. B(a)p concentrations in the street canyons were commonly low at the urban background level, and the highest concentrations were measured in detached house areas, typically on Saturdays, when sauna stoves are often used. So, it was shown that even though most PAH compounds measured at Virolahti came in the burning factor consisting of mixed emissions from traffic, energy 
production, and biomass burning from the direction of St. Petersburg, b(a)p measured in HMA mainly originates from wood burning emissions.

Forests are an important source of volatile organic compounds in the atmosphere. VOCs are oxidized in the atmosphere at various speeds, and they form secondary organic aerosol (SOA). It has been estimated that, despite massive anthropogenic pollution, biogenic SOA sources are still globally dominating. Selected biogenic acids that are oxidation products of biogenic VOCs were analyzed from the boreal forest in Hyytiälä. The highest terpenoid acid concentrations were measured in summer, but high concentrations were also measured occasionally in winter. Peak concentrations in summer were expected, as these acids are reaction products of light- or temperature-dependent emissions of the parent terpenoids, and winter peak emissions were assumed to come from nearby sawmills. It appeared that sesquiterpene emissions from boreal forests were probably underestimated. Measured terpenoic acids comprised only a small fraction $(\sim 1-3 \%)$ of the total OC in particles measured at the site, and only $0.2-0.7 \%$ of the $\mathrm{PM}_{1}$ mass. However, $\beta$-caryophyllinic and caric acids were weakly correlated with the accumulation-mode particle number concentrations, which implicates that they participate in the particle growth process.

VOC sources in Hyytiälä were investigated using PMF. Spruce was found to be the main sesquiterpene emitter in the area, and the main monoterpene source was temperature-dependent pine emissions. However, the sources that mostly correlated with aerosol volume were lightdependent conifer emissions and monoterpenes containing a photochemistry-dependent source. This is understandable, as new particle formation in forests have been found to be strongly dependent on photochemistry, and these semi volatile VOC oxidation products are probably important in particle growth. In this kind of case, the dynamic nature of the source profiles must be acknowledged. Sources of emission products, that were formed on the way from the source to the receptor, were modeled. VOC profiles measured at the receptor are not fully comparable to real emissions. These are challenging situations regarding source apportionment, and the model user must be aware of that. It was shown that PMF can also be used to estimate separate sources in the quasistationary dynamic system, like ambient VOC concentrations in the boreal forest. PMF has been used for source apportionment of VOCs before, but in those cases, biogenic VOC compounds were typically classified as one biogenic source without going into separate sources in this biogenic class.

Source apportionment was made for long time series of atmospheric trace elements and persistent organic compounds measured at the remote background site, Pallas. It was found that a major source of heavy metals like $\mathrm{Ni}, \mathrm{Cu}, \mathrm{As}, \mathrm{Co}$, and $\mathrm{SO}_{2}$ is the Kola Peninsula area in Northwestern Russia. This was expected because heavy metal emissions from this area were known to be huge compared to other emission sources in the Arctic. Other sources were soil, marine, secondary LRT, and combustion-related LRT. According to trajectory analysis, both LRT factors came from the south, indicating sources from Finland and Eastern Europe/Western Russia. Of these, combustion-related long-range transport and soil sources were found to contribute most to PM mass at Pallas. 
For source apportionment of combined POP and trace element time series, a similar five-factor solution was found to best describe the data. This is a good thing because similar factors were expected to be found, and they also validated the model result. However, there were also few differences. Soil, marine, and heavy metal sources were quite similar to the trace elements PMF. Most PAHs were apportioned in the combustion factor related to energy production, with domestic Finland as the main source area. Wood burning traces were split into three sources, with half of the potassium coming from an LRT source from south of Pallas, domestic Finland, and Eastern Europe.

POPs were split into three main sources. One was a burning source with the majority of PAHs. Another was LRT from the south. These are expected results, as these compounds still exist in the environment, e.g., in soil particles, and even half of the PCBs ever produced are still lying somewhere in old landfills, disintegrating transformers, etc. The main finding of this study was that some POPs came along the marine source from clean areas north of Pallas, where there should be no remarkable POP sources. One interpretation for this is that these long-lived compounds that, for many decades, migrated into the Arctic from southern areas along the air and sea currents and deposited into ice, are now released back into the atmosphere from the melting Arctic ice cover due to global warming.

\subsection{Conclusions}

In general, air quality in Finland is good. However, there are also some air quality problems, such as PAH pollution from wood burning, that are not properly addressed due to relatively rare measurements, at least when comparing to common and widespread wood burning in Finland. There will be a transition from fossil fuels toward biofuels in energy production and in traffic as the need for more common and frequent PAH measurements increases in order to estimate the environmental impact of these changes.

Secondary organic aerosol production from vegetation, especially from forests, is still partly unknown. The effect of sesquiterpenes on aerosol production is probably underestimated, at least in boreal areas. There is intensive research on this topic. In this work, it was proven that PMF is a useful tool to address the sources even in quasistationary systems such as biogenic VOC emissions in the boreal forest. PMF is already a widely used source apportionment method and is the most used receptor modeling method nowadays, with many applications in the area of air pollution. However, the error estimation of the model result is still uncertain and difficult to estimate, and there is still work to improve the model in this area.

Trace element sources were estimated at Pallas. The major source of atmospheric $\mathrm{Ni}, \mathrm{Cu}$, and As and sulfuric emissions in the Arctic area at the Kola Peninsula has now announced the closing of its metal smelter, and sulfur emissions in air and emissions of some heavy metals are expected to decrease radically. Research and measurements are still needed to address the effect of these actions on air quality, and even more on the state of the environment in the Arctic area. 
POPs remain an environmental problem, even though manufacturing and the use of these compounds have been restricted or banned for decades. New POP compounds are also being developed. Global warming has also generated new problems here, as the Arctic has now turned from the sink into a source for some of these compounds, as was shown in this work, and even though primary emissions have decayed, some of these compounds are now coming back in detectable concentrations from their storage pools in the melting ice and warming ocean. There is a continuous need to monitor these compounds and research this topic to estimate the environmental impact of this change. 


\section{REFERENCES}

Almeida, S.M., Manousakas, M., Diapouli, E., Kertesz, Z., Samek, L., Hristova, E., Šega, K., Padilla Alvarez, R., Belis, C.A., Eleftheriadis, K. Ambient particulate matter source apportionment using receptor modelling in European and Central Asia urban areas, Environmental Pollution, Volume 266, No. 3, 2020, 115199, ISSN 0269-7491, https://doi.org/10.1016/j.envpol.2020.115199.

Alves, C.A., Vicente, A.M., Custódio, D., Cerqueira, M., Nunes, T., Pio, C., Lucarelli, F., Calzolai, G., Nava, S., Diapouli, E., Eleftheriadis, K., Querol, X., Bandowe, B.A.M.

Polycyclic aromatic hydrocarbons and their derivatives (nitro-PAHs, oxygenated PAHs, and azaarenes) in PM2.5 from Southern European cities, Science of The Total Environment, Volume 595, 2017, 494-504, ISSN 0048-9697, https://doi.org/10.1016/j.scitotenv.2017.03.256.

AMAP, 2009. Arctic Pollution 2009. Arctic Monitoring and Assessment Programme, Oslo. 83 pp. ISBN 978-82-7971-050-9

Anttila, P., Brorström-Lundén, E., Hansson, K., Hakola, H., Vestenius, M. Assessment of the spatial and temporal distribution of persistent organic pollutants (POPs) in the Nordic atmosphere, Atmospheric Environment, Volume 140, 2016, 22-33, ISSN 1352-2310, https://doi.org/10.1016/j.atmosenv.2016.05.044.

Aurela, M. Chemical and source characterisation of ambient fine particles with off-line and online methods, Finnish Meteorological Institute Contributions No. 120, FMI-CONT-120, May 2016.

Balmer, J.E., Hung, H., Yu, Y., Letcher, R.J., Muir, D.C.G. Sources and environmental fate of pyrogenic polycyclic aromatic hydrocarbons (PAHs) in the Arctic, Emerging Contaminants, Volume 5, 2019, 128-142, https://doi.org/10.1016/j.emcon.2019.04.002.

Barreira, L.M.F., Ylisirniö, A., Pullinen, I., Buchholz, A., Li, Z., Lipp, H., Junninen, H., Hõrrak, U., Noe, S.M., Krasnova, A., Krasnov, D., Kask, K., Talts, E., Niinemets, Ü., Ruiz-Jimenez, J., Schobesberger, S. The importance of sesquiterpene oxidation products for secondary organic aerosol formation in a springtime hemiboreal forest, Atmospheri Chemistry and Physics, Volume 21, 2021, 11781-11800, https://doi.org/10.5194/acp-21-11781-2021, 2021.

Baskaran, M. 2011. Po-210 and $\mathrm{Pb}-210$ as atmospheric tracers and global atmospheric $\mathrm{Pb}-210$ fallout: A Review. Journal of Environmental Radioactivity, Volume 102, 500-513.

Belis, C.A., Karagulian, F., Larsen, B.R., Hopke, P.K. Critical review and meta-analysis of ambient particulate matter source apportionment using receptor models in Europe, Atmospheric Environment, Volume 69, 2013, 94-108, ISSN 1352-2310, https://doi.org/10.1016/j.atmosenv.2012.11.009.

Belis, C.A., Pikridas, M., Lucarelli, F., Petralia, E., Cavalli, F., Calzolai, G., Berico, M., Sciare, J. Source apportionment of fine PM by combining high time resolution organic and inorganic 
chemical composition datasets, Atmospheric Environment: X, Volume 3, 2019, 100046, ISSN 2590-1621, https://doi.org/10.1016/j.aeaoa.2019.100046.

Bidleman, T.F., Jantunen, L.M., Hung, H., Ma, J., Stern, G.A., Rosenberg, B., Racine, J. Annual cycles of organochlorine pesticide enantiomers in Arctic air suggest changing sources and pathways, Atmospheric Chemistry and Physics, Volume 15, 1411-1420, https://doi.org/10.5194/acp-15-1411-2015.

Blomqvist, P., Persson, H., Van Hees, P., Holmstedt, G., Göransson, U., Wadsö, L., Sanati, M., Rupar-Gadd, K. 2007. An experimental study of spontaneous ignition in storages of wood pellets. In: Fire and Materials Conference (San Francisco, USA).

Bond, T. C., S. J. Doherty, D. W. Fahey, P. M. Forster, T. Berntsen, B. J. DeAngelo, M. G. Flanner, et al. 2013. "Bounding the Role of Black Carbon in the Climate System: A Scientific Assessment." Journal of Geophysical Research: Atmospheres 118 (11): 5380-5552. doi:10.1002/jgrd.50171.

Cabrerizo, A., Muir, D.C.G., De Silva, A.O., Wang, X., Lamoureux, S.F., Lafrenière, M.J. Legacy and emerging persistent organic pollutants (POPs) in terrestrial compartments in the High Arctic: Sorption and secondary sources, Environmental Science \& Technology,

Volume 52, No. 24, 2018, 14187-14197, DOI: 10.1021/acs.est.8b05011.

Carslaw, D.C. 2015. The Openair Manual. Open-source Tools for Analysing Air Pollution Data. Manual for Version 1.1-4, King's College London.

Carslaw, D.C., 2018. Package "Openair." Tools for the analysis of air pollution data. http://davidcarslaw.github.io/openair/.

Carslaw D.C., Ropkins K. 2012. Openair — an R package for air quality data analysis, Environmental Modelling Software , 2012, 27-28, 52-61.

CEN, 2014. Standard method EN 12341:2014. Ambient air - Standard gravimetric measurement method for the determination of the PM10 or PM2.5 mass concentration of suspended particulate matter.

CEN, 2008. UNE EN 15549:2008. Air quality. Standard method for the measurement of the concentration of benzo(a)pyrene in ambient air. European Committee for Standardization.

Cotham, W.E., Bidleman, T.F. Polycyclic aromatic hydrocarbons and polychlorinatedbiphenyls in air at an urban and rural site near Lake Michigan, Environmental Science and Technology, Volume 29, 1995, 2782e2789.

Crippa, M., Canonaco, F., Lanz, V., Aijala, M., Allan, J., Carbone, S., Capes, G., Ceburnis, D., Dall'Osto, M., Day, D., DeCarlo, P., Ehn, M., Eriksson, A., Freney, E., Hildebrandt Ruiz, L., Hillamo, R., Jimenez, J., Junninen, H., Kiendler-Scharr, A., Kortelainen, A., Kulmala, M., Laaksonen, A., Mensah, A., Mohr, C., Nemitz, E., O’Dowd, C., Ovadnevaite, J., Pandis, S., Petaja, T., Poulain, L., Saarikoski, S., Sellegri, K., Swietlicki, E., Tiitta, P., Worsnop, D., Baltensperger, U., Prevot, A. Organic aerosol components derived from 25 AMS data sets across Europe using a consistent ME-2 based source apportionment approach, Atmospheric Chemistry and Physics, Volume 14, 2014, 6159-6176. 
Crippa, M., DeCarlo, P.F., Slowik, J.G., Mohr, C., Heringa, M.F., Chirico, R., Poulain, L., Freutel, F., Sciare, J., Cozic, J., Di Marco, C.F., Elsasser, M., Nicolas, J.B., Marchand, N., Abidi, E., Wiedensohler, A., Drewnick, F., Schneider, J., Borrmann, S., Nemitz, E., Zimmermann, R., Jaffrezo, J.-L., Prévôt, A.S.H., Baltensperger, U. Wintertime aerosol chemical composition and source apportionment of the organic fraction in the metropolitan area of Paris, Atmospheric Chemistry and Physics, Volume 13, 961-981, https://doi.org/10.5194/acp-13-961-2013.

Cui, T., Zeng, Z., dos Santos, E.O., Zhang, Z., Chen, Y., Zhang, Y., Rose, C.A., Budisulistiorini, S.H., Collins, L.B., Bodnar, W.M. Development of a hydrophilic interaction liquid chromatography (HILIC) method for the chemical characterization of watersoluble isoprene epoxydiol (IEPOX)-derived secondary organic aerosol, Environmental Science: Processes \& Impacts, Volume 20, 2018, 1524, DOI: 10.1039/C8EM00308D.

Durnford, D., Dastoor, A., Figueras-Nieto, D., Ryjkov, A. Long range transport of mercury to the Arctic and across Canada, Atmospheric Chemistry and Physics, Volume 10, 2010, 60636086.

EC, 2021. Air Quality in Europe - 2020 Report, https://www.eea.europa.eu/publications/airquality-in-europe-2020-report, accessed 11.4.2021.

Eckley, C.S., Gustin, M., Lin, C.-J., Li, X., Miller, M.B. The influence of dynamic chamber design and operating parameters on calculated surface-to-air mercury fluxes, Atmospheric Environment, Volume 44, 2010, 194-203.

EEA. 2019a. European Union emission inventory report 1990-2017 under the UNECE Convention on Long-range Transboundary Air Pollution (LRTAP). EEA Report No 08/2019, European Environment Agency, Copenhagen. ISBN 978-92-9480-078-7, ISSN 1977-8449, 148 pp.

EEA. 2019b. Air quality in Europe - 2019 report. EEA Report No 10/2019. European Environment Agency, Luxembourg. ISBN 978-92-9480-088-6, ISSN 1977-8449, 104 pp.

Ehn, M., Thornton, J.A., Kleist, E., Sipilä, M., Junninen, H., Pullinen, I., Springer, M., Rubach, F., Tillmann, R., Lee, B., Lopez-Hilfiker, F., Andres, S., Acir, I-H. Rissanen, M., Jokinen, T., Schobesberger, S., Kangasluoma, J., Kontkanen, J., Nieminen, T., Kurtén, T., Nielsen, L.B., Jørgensen, S., Kjaergaard, H.G., Canagaratna, M., Dal Maso, M., Berndt, T., Petäjä, T., Wahner, A., Kerminen, V-M., Kulmala, M., Worsnop, D.R., Wildt, J., and Mentel, T.F,, A large source of low-volatility secondary organic aerosol, Nature, Volume 506, 2014, 476-479. https://doi.org/10.1038/nature13032.

EMEP. 1996. EMEP manual for sampling and chemical analysis. EMEP/CCC-Report 1/95. Norwegian Institute for Air Research, Kjeller. http://www.nilu.no/projects/ ccc/manual/

EMEP 2020. Gusev, A. and Batrakova, N., Assessment of PAH pollution levels, key sources and trends: contribution to analysis of the effectiveness of the POPs Protocol, MSC-E Technical Report 2/2020 June 2020

ETC/ACM. 2014. ETC/ACM Technical Paper 2014/6, European Topic Centre on Air 
Pollution and Climate Change Mitigation.

ETC/ACM. 2020. EEA Report No 9/2020. Air quality in Europe - 2020 report.

EU. 2004. Directive 2004/107/EC of the European Parliament and of the Council of 15 December 2004 relating to arsenic, cadmium, mercury, nickel and polycyclic aromatic hydrocarbons in ambient air. Off J, Volume 23, 2005, 3-16, URL: http://eurlex.europa.eu/LexUriServ/LexUriServ.do?uri=OJ:L:2005:023:0003:0016:EN:PDF, accessed 5.2021 .

EU. 2008. Directive 2008/50/EC of the European Parliament and of the Council of 21 May 2008 on ambient air quality and cleaner air for Europe. Off J 2008, L 152, 1-44, URL: http://eur-lex.europa.eu/legal-content/EN/TXT/PDF/?uri=CELEX:32008L0050\&from=EN, accessed 5.2021.

FMI. 2021. https://www.ilmatieteenlaitos.fi/pah-yhdisteet (23.9.2021).

Fritsche, J., Obrist, D., Zeeman, M.J., Conen, F., Eugster, W., Alewell, C. Elemental mercury fluxes over a sub-alpine grassland determined with two micrometeorological methods. Atmospheric Environment, Volume 42, 2008, 2922-2933.

Glasius, M., Hansen, A.M.K., Claeys, M., Henzing, J.S., Jedynska, A.D., Kasper-Giebl, A., Kistler, M., Kristensen, K., Martinsson, J., Maenhaut, W., Nøjgaard, J.K., Spindler, G., Stenström, K.E., Swietlicki, E., Szidat, S., Simpson, D., Yttri, K.E. Composition and sources of carbonaceous aerosols in Northern Europe during winter, Atmospheric Environment, Volume 173, 2018, 127-141, https://doi.org/10.1016/j.atmosenv.2017.11.005.

Glasius, M., Ketzel, M., Wåhlin, P., Bossi, R., Stubkjær, J., Hertel, O., Palmgren, F. Characterization of particles from residential wood combustion and modelling of spatial variation in a low-strength emission area. Atmospheric Environment, Volume 42, 2008, $8686 \mathrm{e} 8697$.

Griffin, R.J., Cocker, D.R., Seinfeld, J.H., Dabdub, D. Estimate of global atmospheric organic aerosol from oxidation of biogenic hydrocarbons, Geophysical Research Letters, Volume 26, No. 17, 1999, 2721-2724, DOI: 10.1029/1999GL900476.

Guenther, A., Jiang, X., Heald, C., Sakulyanontvittaya, T., Duhl, T., Emmons, L., Wang, X. The model of emissions of gases and aerosols from nature version 2.1 (MEGAN2.1): An extended and updated framework for modeling biogenic emissions. Geoscientific Model Development (GMD), Volume 5, 2012, 1471-1492.

Hakola, H., Laurila, T., Lindfors, V., Hellén, H., Gaman, A., Rinne, J. Variation of the VOC emission rates of birch species during the growing season. Boreal Environmental Research, Volume 6, 2001, 237-249.

Hakola, H., Tarvainen, V., Bäck, J., Ranta, H., Bonn, B., Rinne, J., Kulmala, M. Seasonal variation of mono- and sesquiterpene emission rates of Scots pine, Biogeosciences, Volume 3, 2006, 93-101, doi:10.5194/bg-3-93-2006, 2006.

Hallquist, M., Wenger, J.C., Baltensperger, U., Rudich, Y., Simpson, D., Claeys, M., Dommen, 
J., Donahue, N.M., George, C., Goldstein, A.H., Hamilton, J.F., Herrmann, H., Hoffmann, T., Iinuma, Y., Jang, M., Jenkin, M.E., Jimenez, J.L., Kiendler-Scharr, A., Maenhaut, W., McFiggans, G., Mentel, Th.F., Monod, A., Prévôt, A.S.H., Seinfeld, J.H., Surratt, J.D., Szmigielski, R., Wildt, J. The formation, properties and impact of secondary organic aerosol: Current and emerging issues, Atmospheric Chemistry and Physics, Volume 9, 2009, 51555236, doi:10.5194/acp-9-5155- 2009.

Haywood, J. \& Boucher, Olivier. (2000). Estimates of the direct and indirect radiative forcing due to tropospheric aerosols: A review. Reviews of Geophysics. 38. 10.1029/1999RG000078.

Hänninen, O., Knol, A.B., Jantunen, M., Lim, T.A., Conrad, A., Rappolder, M., Carrer, P., Fanetti, A.C., Kim, R., Buekers, J., Torfs, R., Iavarone, I., Classen, T., Hornberg, C., Mekel, O.C., EBoDE Working Group. Environmental burden of disease in Europe: Assessing nine risk factors in six countries. Environmental Health Perspectives, Volume 122, 2014, 439-446, http://dx.doi.org/10.1289/ehp.1206154.

Hedberg, E., Kristensson, A., Ohlsson, M., Johansson, C., Johansson, P.-Å., Swietlicki, E., Vesely, V., Wideqvist, U., Westerholm, R. Chemical and physical characterization of emissions from birch wood combustion in a wood stove. Atmospheric Environment, Volume 36, 2002, $4823 \mathrm{e} 4837$.

Hellén H., Praplan A.P., Tykkä T., Ylivinkka I., Vakkari V., Bäck J., Petäjä T., Kulmala M., Hakola H. Long-term measurements of volatile organic compounds highlight the importance of sesquiterpenes for the atmospheric chemistry of a boreal forest, Atmospheric Chemistry and Physics, Volume 18, 2018, 13839-13863.

Hellén, H., Hakola, H., Haaparanta, S., Pietarila, S., Kauhaniemi, M. Influence of residential wood combustion on local air quality. Science of the Total Environment, Volume 393, 2008, $283 \mathrm{e} 290$.

Hellén, H., Hakola, H., Pystynen, K.-H., Rinne, J., Haapanala, S. $\mathrm{C}_{2}-\mathrm{C}_{10}$ hydrocarbon emissions from a boreal wetland and forest floor, Biogeosciences, Volume 3, 2006, 167-174, doi:10.5194/bg-3-167- 2006.

Hellén, H., Praplan, A.P., Tykkä, T., Helin, A., Schallhart, S., Schiestl-Aalto, P.P., Bäck, J., Hakola, H. Sesquiterpenes and oxygenated sesquiterpenes dominate the VOC $\left(\mathrm{C}_{5}-\mathrm{C}_{20}\right)$ emissions of downy birches, Atmospheric Chemistry and Physics, Volume 21, 2021, 80458066, https://doi.org/10.5194/acp-21-8045-2021.

Hopke, P. Review of receptor modeling methods for source apportionment. Journal of the Air \& Waste Management Association, Volume 66, 2016, 237-259.

Hopke, P.K., Dai, Q., Li, L., Feng, Y. Global review of recent source apportionments for airborne particulate matter. Science of The Total Environment, Volume 740, 2020.

Hung, H., Katsoyiannis, A.A., Brorström-Lundén, E., Olafsdottird, K., Aas, W., Breivik, K., Bohlin-Nizzetto, P., Sigurdsson, A., Hakola, H., Bossi, R., Skov, H., Sverko, E., Barresi, E., Fellin, P., Wilson, S. Temporal trends of persistent organic pollutants (POPs) in Arctic air: 20 years of monitoring under the Arctic Monitoring and Assessment Programme (AMAP) Environmental Pollution, 2016, 10.1016/j.envpol.2016.01.079. 
Hyvärinen, A.P., Kolmonen, P., Kerminen, V.M., Virkkula, A., Leskinen, A., Komppula, M., Hatakka, J., Burkhart, J., Stohl, A., Aalto, P., Kulmala, M., Lehtinen, K.E.J., Viisanen, Y., Lihavainen, H. (2011) Aerosol black carbon at five background measurement sites over Finland, a gateway to the Arctic. Atmospheric.Environment, Volume 45, 2011, 4042-4050.

IEA. 2020., World Energy Balances: Overview, IEA, Paris, https://www.iea.org/reports/worldenergy-balances-overview.

Irei, S., Stupak, J., Gong, X., Chan, T-W., Cox, M., McLaren, R., Rudolph, J. Molecular marker study of particulate organic matter in Southern Ontario air, Journal of Analytical Methods in Chemistry, Volume 2017, 2017 Article ID 3504274, 19 pages, https://doi.org/10.1155/2017/3504274.

Isaacman, G., Kreisberg, N.M., Yee, L.D., Worton, D.R., Chan, A.W.H., Moss, J.A., Hering, S.V., Goldstein, A.H. Online derivatization for hourly measurements of gas-and particle-phase semi-volatile oxygenated organic compounds by thermal desorption aerosol gas chromatography (SV-TAG). Atmospheric Measurement Techniques (AMT), Volume 7, 2014, 4417-4429, DOI: 10.5194/amt-7-4417-2014, ISBN 978-92-9480-292-7, ISSN 1977-8449, doi: $10.2800 / 786656$.

Jimenez, J., Donahue, N., Prevot, A., Zhang, Q., Kroll, J., DeCarlo, P., Allan, J.D., Coe, H., Ng, N., Aiken, A., Docherty, K., Ulbrich, I., Grieshop, A., Robinson, A.L., Duplissy, J., Smith, J., Wilson, K., Lanz, V.A., Worsnop, D. Evolution of organic aerosols in the atmosphere, Science (New York, N.Y.), Volume 326, 2009, 1525-1529, 10.1126/science.1180353.

Johnson, D., Utembe, S.R., Jenkin, M.E. Simulating the detailed chemical composition of secondary organic aerosol formed on a regional scale during the TORCH 2003 campaign in the southern UK, Atmospheric Chemistry and Physics, Volume 6, 2006, 419-431, https://doi.org/10.5194/acp-6-419-2006.

Kampf, C., Corrigan, A., Johnson, A., Song, W., Keronen, P., Konigstedt, R., Williams, J., Russell, L., Petaja, T., Fischer, H., Hoffmann, T. First measurements of reactive alphadicarbonyl concentrations on PM2.5 aerosol over the Boreal forest in Finland during HUMPPA-COPEC 2010-source apportionment and links to aerosol aging, Atmospheric Chemistry and Physics, Volume 12, 2012, 6145-6155.

Kanakidou, M., Seinfeld, J.H., Pandis, S.N., Barnes, I., Dentener, F.J., Facchini, M.C., Van Dingenen, R., Ervens, B., Nenes, A., Nielsen, C.J., Swietlicki, E., Putaud, J.P., Balkanski, Y., Fuzzi, S., Horth, J., Moortgat, G.K., Winterhalter, R., Myhre, C.E.L., Tsigaridis, K., Vignati, E., Stephanou, E.G., Wilson, J. Organic aerosol and global climate modelling: A review, Atmospheric Chemistry and Physics, Volume 5, 2005, 1053-1123, doi:10.5194/acp-5-10532005.

Khan, M.A.H., Jenkin, M.E., Foulds, A., Derwent, R.G., Percival, C.J., Shallcross, D.E. A modeling study of secondary organic aerosol formation from sesquiterpenes using the STOCHEM global chemistry and trans port model, Journal of Geophysical Research: Atmospheres, Volume 122, 2017, 4426-4439, https://doi.org/10.1002/2016JD026415.

Kiendler-Scharr, A., Wildt, J., Dal Maso, M., Hohaus, T., Kleist, E., Mentel, T.F., Tillmann, R., Uerlings, R., Schurr, U., Wahner, A. New particle formation in forests inhibited by isoprene 
emissions. Nature, Volume 461, No. 7262, 2009 Sep 17, 381-384, doi: 10.1038/nature08292, PMID: 19759617.

Krauss, M., Wilcke, W. Sorption strength of persistent organic pollutants in particle-size fractions of urban soils, Soil Science Society of America Journal, Volume 66, 2002, 430-437, https://doi.org/10.2136/sssaj2002.4300.

Kukkonen, J., López-Aparicio, S., Segersson, D., Geels, C., Kangas, L., Kauhaniemi, M., Maragkidou, A., Jensen, A., Assmuth, T., Karppinen, A., Sofiev, M., Hellén, H., Riikonen, K., Nikmo, J., Kousa, A., Niemi, J.V., Karvosenoja, N., Santos, G.S., Sundvor, I., Im, U., Christensen, J.H., Nielsen, O.-K., Plejdrup, M.S., Nøjgaard, J.K., Omstedt, G., Andersson, C., Forsberg, B., Brandt, J. The influence of residential wood combustion on the concentrations of $\mathrm{PM}_{2.5}$ in four Nordic cities, Atmospheric Chemistry and Physics, Volume 20, 2020, 4333-4365, https://doi.org/10.5194/acp-20-4333-2020.

Kulkarni, P. Baron, P.A., Willeke, K. 2011. Aerosol Measurement, Principles, Techniques and Applications, 3rd ed., John Wiley \& Sons, New Jersey.

Kulmala, M., Suni, T., Lehtinen, K.E.J., Dal Maso, M., Boy, M., Reissell, A., Rannik, Ü., Aalto, P., Keronen, P., Hakola, H., Bäck, J., Hoffmann, T., Vesala, T., Hari, P. A new feedback mechanism linking forests, aerosols, and climate, Atmospheric Chemistry and Physics, Volume 4, 2004, 557-562, doi:10.5194/acp-4-557-2004.

Kulmala, M., Hienola, J., Hämeri, K., Pirjola, L., ja Vesala, T. Fysiikka, kemia ja ympäristöongelmat, Report series in aerosol science, part B, nr. B3, 1999.

Kyllönen, K. Fluxes, trends and source characterisation of atmospheric trace elements, Academic dissertation, Finnish Meteorological Institute contributions 164, 2020, ISBN 978952-336-104-1 (pdf), 978-952-336-103-4 (paperback).

Laakso, L., Hussein, T., Aarnio, P., Komppula, M., Hiltunen, V., Viisanen, Y., Kulmala, M. Diurnal and annual characteristics of particle mass and number concentrations in urban, rural and arctic environments in Finland. Atmospheric Environment, Volume 37, No. 19, 2003, $2629-2641$

Lammel G. Polycyclic aromatic compounds in the atmosphere - A review identifying research needs, Polycyclic Aromatic Compounds, Volume 35, Nos. 2-4, 2015, 316-329, DOI: 10.1080/10406638.2014.931870.

Lammel, G., Dvorská, A., Klanova, J., Kohoutek, J., Kukucka, P., Prokeš, R., Sehili, A. Longrange atmospheric transport of polycyclic aromatic hydrocarbons is worldwide problem Results from measurements at remote sites and modelling, Acta Chimica Slovenica, Volume 62, 2015, 729-735, 10.17344/acsi.2015.1387.

Lee, A., Goldstein, A.H., Keywood, M.D., Gao, S., Varutbangkul, V., Bahreini, R., Ng, N.L., Flagan, R.C., Seinfeld, J.H. Gas-phase products and secondary aerosol yields from the ozonolysis of ten different terpenes, Journal of Geophysical Research, Volume 111, 2006, D07302 DOI: 10.1029/2005JD006437. 
Letcher RJ, Bustnes JO, Dietz R, Jenssen BM, Jørgensen EH, Sonne C, Verreault J, Vijayan MM, Gabrielsen GW. Exposure and effects assessment of persistent organohalogen contaminants in arctic wildlife and fish. Science of Total Environment (2010) Jul 1;408(15):2995-3043. doi: 10.1016/j.scitotenv.2009.10.038. Epub 2009 Nov 12. PMID: 19910021.

Li, H., Riva, M., Rantala, P., Heikkinen, L., Daellenbach, K., Krechmer, J.E., Flaud, P.-M., Worsnop, D., Kulmala, M., Villenave, E., Perraudin, E., Ehn, M., Bianchi, F. Terpenes and their oxidation products in the French Landes forest: Insights from Vocus PTR-TOF measurements, Atmospheric Chemistry and Physics, Volume 20, 2020, 1941-1959. https://doi. org/10.5194/acp-20-1941-2020.

McCarthy, M.C., Aklilu, Y.-A., Brown, S.G., Lyder, D.A. Source apportionment of volatile organic compounds measured in Edmonton, Atmospheric Environment, Volume 81, 2013, $504-516$.

Makkonen, U. Measurement of inorganic ions and their precursors gases in ambient air in Finland, Finnish Meteorological Institute contributions 110, 2014, ISBN 978-951-697-791-1 (pdf), 978-951-697-791-4 (paperback).

Mattsson, R., Paatero J., Hatakka, J. Automatic alpha/beta analyser for air filter samples Absolute determination of Radon progeny by pseudo-coincidence techniques, Radiation Protection Dosimetry, Volume 63, 1996, 133-139.

Mesquita, S.R., van Drooge, B., Barata, C., Vieira, N., Guimarães, L., Piña, B. Toxicity of atmospheric particle-bound PAHs: An environmental perspective, Environmental Science and Pollution Research, Volume 21, No. 20, 2014, 11623-11633, https://doi.org/10.1007/S11356014-2628-Y.

NOAA. Stein, A., Draxler, R.R., Rolph, G., Stunder, B., Cohen, M.D., Ngan, F. NOAA's HYSPLIT atmospheric transport and dispersion modeling system. Bulletin of the American Meteorological Society, Volume 96, 2016, 150504130527006, 10.1175/BAMS-D-14-00110.1.

Nornickel. https://www.nornickel.com/news-and-media/press-releases-and-news/nornickelcuts-emissions-at-kola-peninsula-by-85-in-2021/type=esg, 2021, accessed 8.17.2021.

OECD. The economic cost of air pollution: Evidence from Europe, Economics Department Working Paper No 1584, Organisation for Economic Co-operation and Development, Paris, 2019, (http://www.oecd.org/officialdocuments/publicdisplaydocument.pdf/?cot $\mathrm{e}=\mathrm{ECO} / \mathrm{WKP}(2019) 54 \&$ docLanguage $=$ En), accessed 10.21.2020.

Paatero, J., Hatakka, J. 1997. Measurements of Long-lived Radioactivity in the Air and Precipitation in Finland 1991-1994. Publications on Air Quality No. 26, Finnish Meteorological Institute, Helsinki, 71 pp.

Paatero J., Dauvalter V., Derome J., Lehto J., Pasanen J., Vesala T., Miettinen J., Makkonen U., Kyrö E.-M., Jernström J., Isaeva L., Derome K. 2008. Effects of Kola Air Pollution on the Environment in the Western Part of the Kola Peninsula and Finnish Lapland - Final Report. ISBN 978-951-697-686-3, ISNN 0782-6079, 26 pp. 
Paatero P. Least squares formulation of robust non-negative factor analysis. Chemometrics and Intelligent Laboratory Systems., Volume 37, 1997, 23-35.

Paatero P., Tapper U. Positive matrix factorization: A non-negative factor model with optimal utilization of error estimates of data values. Environmetrics, Volume 5, 1994, 111-126.

Paatero P., Eberly S., Brown S.G., Norris G.A. Methods for estimating uncertainty in factor analytic solutions. Atmospheric. Measurement. Techniques., Volume 7, 2014, 781-797.

Paatero, P., Hopke, P.K., 2003. Discarding or downweighting high-noise variables in factor analytic models. Analytica Chimica Acta 490, 277e289.

Pachon J.E., Weber R.J., Zhang X., Mulholland J.A., Russell A.G. Revising the use of potassium $(\mathrm{K})$ in the source apportionment of PM2.5. Atmospheric Pollution Research, Volume 4, 2013, 14-21.

Pakkanen T.A., Kerminen V.-M., Korhonen C.H., Hillamo R.E., Aarnio P., Koskentalo T., Maenhaut W. Use of atmospheric elemental size distributions in estimating aerosol sources in the Helsinki area. Atmospheric Environment, Volume 35, 2001, 5537-5551.

Pant, P., Harrison, R.M. Estimation of the contribution of road traffic emissions to particulate matter concentrations from field measurements: A review, Atmospheric Environment, Volume 77, 2013, 78-97, ISSN 1352-2310, https://doi.org/10.1016/j.atmosenv.2013.04.028.

Park, M., Joo, H.S., Lee, K. Jang, M., Kim, S.D., Kin, I., Borlaza, L.J.S., Lim, H., Shin, H., Chung, K.H., Choi, Y-H., Park, S.G., Bae, M-S., Lee, J., Song., H., Park, K. Differential toxicities of fine particulate matters from various sources. Scientific Reports, Volume 8, 2018, 17007, https://doi.org/10.1038/s41598-018-35398-0.

Pope III, C.A., Dockery D.W. Health effects of fine particulate air pollution: Lines that connect, Journal of the Air \& Waste Management Association, Volume 56, No. 6, 2006, 709-742, DOI: 10.1080/10473289.2006.10464485.

Qian, Y., T. J. Yasunari, S. J. Doherty, M. G. Flanner, W. K. M. Lau, J. Ming, H. Wang, M. Wang, S. G. Warren, and R. Zhang. 2015. "Light-Absorbing Particles in Snow and Ice: Measurement and Modeling of Climatic and Hydrological Impact." Advances in Atmospheric Sciences 32 (1): 64-91. doi:10.1007/s00376-014-0010-0.

Quéléver, L.L.J., Kristensen, K., Normann Jensen, L., Rosati, B., Teiwes, R., Daellenbach, K.R., Peräkylä, O., Roldin, P., Bossi, R., Pedersen, H.B., Glasius, M., Bilde, M., Ehn, M. Effect of temperature on the formation of highly oxygenated organic molecules (HOMs) from alphapinene ozonolysis, Atmospheric Chemistry and Physics, Volume 19, 2019, 76097625, https://doi.org/10.5194/acp-19-7609-2019.

Rahman, M., Hopke, P. Mechanistic pathway of carbon monoxide off-gassing from wood pellets. Energy and Fuels., Volume 30, 2016, 5809-5815.

Ravindra, K., Sokhi, R., Van Grieken, R. Review: Atmospheric polycyclic aromatic hydrocarbons: Source attribution, emission factors and regulation, Atmospheric Environment, 
Volume 42, 2008, 2895-2921.

Rolph G., Stein A., Stunder B. Real-time Environmental Applications and Display sYstem: READY. Environmental Modelling \& Software, Volume 95, 2017, 210-228.

Rosenfeld, D., Lahav, R., Khain, A. \& Pinsky, M. The role of sea spray in cleansing air pollution over ocean via cloud processes. Science, published online doi: 10.1126/science.1074583, (2002)

Ruoho-Airola T., Anttila P., Hakola H., Ryyppö T., Tuovinen J.-P. Trends in the bulk deposition and atmospheric concentration of air pollutants in the Finnish integrated monitoring catchment Pallas during 1992-2012. Boreal Environmental Research, Volume 20, 2015, 553569.

Saarnio, K. Chemical characterization of fine particles from biomass burning, Finnish Meteorological Institute contributions 97, 2013, ISBN 978-951-697-791-1 (pdf), 978-951-697791-4 (paperback).

Sarigiannis, D.A., Kermenidou, M., , Nikolaki, S., Zikopoulos, D., Karakitsios, S.P. Mortality and Morbidity Attributed to Aerosol and Gaseous Emissions from Biomass Use for Space Heating Aerosol and Air Quality Research, 15: 2496-2507, 2015 Copyright (C) Taiwan Association for Aerosol Research ISSN: 1680-8584 print / 2071-1409 online doi: 10.4209/aaqr.2015.03.0149.

Sarkar, C.S., Sinha, V., Panday, B., Rupakheti, A.K., Lawrence, M.G.M. Source apportionment of NMVOCs in the Kathmandu Valley during the SusKat-ABC international field campaign using positive matrix factorization, Volume 17, 2017, 8129-8156.

Savolahti, M., Lehtomäki, H., Karvosenoja, N., Paunu, V.-V., Korhonen, A., Kukkonen, J., Kupiainen, K., Kangas, L., Karppinen, A., Hänninen, O. Residential wood combustion in Finland: $\mathrm{PM}_{2.5}$ emissions and health impacts with and without abatement measures. International Journal of Environmental Research and Public Health, Volume 16, 2019, 2920. https://doi.org/10.3390/ijerph16162920.

Schauer, J.J., Rogge, W.F., Hildemann, L.M., Mazurek, M.A., Cass, G.R., Simoneit, B.R.T. Source apportionment of airborne particulate matter using organic compounds as tracers, Atmospheric Environment, Volume 30, 1996, 3837-3855.

Schneidemesser, Von E., Schauer, J.J., Hagler, G.S.W., Bergin, M.H. Concentrations and sources of carbonaceous aerosol in the atmosphere of Summit, Greenland. Atmospheric Environment, Volume 43, 2009, 4155-4162.

Seinfeld, J.H., Pankow, J.F. Organic atmospheric particulate material, Annual Review of Physical Chemistry., Volume 54, 2003, 121-140, doi: 10.1146/annurev.physchem.54.011002.103756. Epub 2002 Mar 21. PMID: 12524426.

Seinfeld, J.H., Pandis, S.N. 1998. Atmospheric Chemistry and Physics, from Air Pollution to Climate Change, New York, Wiley.

Semeena, V.S., Lammel, G. The significance of the grasshopper effect on the atmospheric distribution of persistent organic substances, Geophysical Research Letters, Volume 32, 2005, L07804, doi:10.1029/2004GL022229. 
Sharma, S., Ishizawa, M., Chan, D., Lavoué, D., Andrews, E., Eleftheriadis, K., Maksyutov, S. 16-year simulation of Arctic black carbon: Transport, source contribution, and sensitivity analysis on deposition, JGR Atmospheres, Volume 118, 2013, 943-964.

Shimada, K., Nohchi, M., Yang, X., Sugiyama, T., Miura, K., Takami, A., Sato, K., Chen, X., Kato, S., Kajii, Y., Meng, F., Hatakeyama, S. Degradation of PAHs during long range transport based on simultaneous measurements at Tuoji Island, China, and at Fukue Island and Cape Hedo, Japan, Environmental Pollution, Volume 260, 2020, 113906, ISSN 0269-7491, https://doi.org/10.1016/j.envpol.2019.113906.

Shrivastava, M., Lou, S., Zelenyuk, A., Easter, R.C., Corley, R., Thrall, B.D., Rasch, P.J., Fast, J.D., Massey Simonich, S.L., Shen, H., Tao, S. 2017. Global Long-Range Transport and LungCancer Risk from Polycyclic Aromatic Hydrocarbons Shielded by Coatings of Organic Aerosol, Proceedings of the National Academy of Sciences of the United States of America, Volume 114 No. 6, 1246-1251. DOI:10.1073/pnas.1618475114.

Sillanpää, M., Frey, A., Hillamo, R., Pennanen, A.S., Salonen, R.O. Organic, elemental and inorganic carbon in in particulate matter in six urban environments in Europe, Atmospheric Chemistry and Physics, Volume 5, 2005, 2869-2879.

Sillanpää, M., Hillamo, R., Saarikoski, S., Frey, A., Pennanen, A., Makkonen, U., Spolnik, Z., Van Grieken R., Branis M., Brunekreef, B., Chalbot, M.-C., Kuhlblush, T., Sunyer, J., Kerminen, V.-M., Kulmala, M., Salonen, R.O. Chemical composition and mass closure of particulate matter in six cities in Europe, Atmospheric Environment, Volume 40 No. S2, 2006, 212-223.

Simoneit, B.R.T. Organic matter of the troposphere-III: Characterization and sources of petroleum and pyrogenic residues in aerosols over the western United States, Atmospheric Environment, Volume 18, 1984, 51-67.

Simoneit, B.R.T., Schauer, J.J., Nolte, C.G., Oros, D.R., Elias, V.O., Fraser, M.P., Rogge, W.F., and Cass, G.R.,Levoglucosan, a tracer for cellulose in biomass burning and atmospheric particles, Atmospheric Environment,Volume 33, Issue 2, 1999, Pages 173-182, ISSN 13522310, https://doi.org/10.1016/S1352-2310(98)00145-9.

Sobek, A., Gustafsson, Ö. Deep water masses and sediments are main compartments of polychlorinated biphenyls in the Arctic Ocean, Environmental Science and Technology, Volume 48 No. 12, 2014, 6719-6725.

Srivastava, D., Favez, O., Petit, J.-E., Zhang, Y., Sofowote, U.M., Hopke, P.K., Bonnaire, N., Perraudin, E., Gros, V., Villenave, E., Albinet, A. Speciation of organic fractions does matter for aerosol source apportionment. Part 3: Combining off-line and on-line measurements, Science of The Total Environment, Volume 690, 2019, 944-955, https://doi.org/10.1016/j.scitotenv.2019.06.378.

Steffen, A., Douglas, T., Amyot, M., Ariya, P., Aspmo, K., Ber, T., Bottenheim, J., Brooks, S., Cobbett, F, Dastoor, A., Dommergue, A., Ebinghaus, R., Ferrari, C., Gardfeldt, K., Goodsite, E., Lean, D., Poulain, A., Scherz, C., Skov, H., Sommar, J., Temme, C. A synthesis of atmospheric mercury depletion event chemistry linking atmosphere, snow and water, Atmospheric Chemistry and Physics, Volume 8, 2008, 1445-1482. 
Stein, A.F., Draxler, R.R., Rolph, G.D., Stunder, B.J.B., Cohen, M.D., Ngan, F. NOAA's Hysplit atmospheric transport and dispersion modeling system. The Bulletin of the American Meteorological Society, Volume 96, 2015, 2059-2077.

Steiner, A.H., Goldstein, A.L. 2007. Biogenic VOCs. In: Volatile Organic Compounds in the Atmosphere, Koppmann, R. (ed.), Blackwell Publishing Ltd, Oxford, 82-128.

Stohl, A., Seibert, P. Accuracy of trajectories as determined from the conservation of meteorological tracers, Quarterly Journal of the Royal Meteorological Society., Volume 124, 1998, 1465-1484.

Stohl, A., Wotawa, G., Seibert, P., Kromp-Kolb, H. Interpolation errors in wind fields as a function of spatial and temporal resolution and their impact on different types of kinematic trajectories. Journal of Applied Meteorology, Volume 34, 1995, 2149-2165.

SYKE. 2021. https://www.ymparisto.fi/fi-FI/Kartat ja tilastot/Ilman_epapuhtauksien paastot, accessed 8.17.2021.

Tarvainen, V., Hakola, H., Hellén, H., Bäck, J., Hari, P., Kulmala, M. Temperature and light dependence of the VOC emissions of Scots pine, Atmospheric Chemistry and Physics, Volume 5, 2005, 989-998, doi:10.5194/acp-5-989-2005.

Tarvainen, V., Hakola, H., Rinne, J., Hellén, H., Haapanala, S. Towards a comprehensive emission inventory of the boreal forest, Tellus, Volume 59 B, 2007, 526-534.

Thurston, G.D., Burnett, R.T., Turner, M.C., Shi, Y., Krewski, D., Lall, R., Ito, K., Jerrett, M., Gapstur, S.M., Diver, R.W., Pope, C.A. Ischemic heart disease mortality and long-term exposure to source-related components of U.S. fine particle air pollution, Environmental Health Perspectives, Volume 124, No. 6, 2016.

Timonen, H., Teinilä, K., Aurela, M., Reyes, F., Vásquez, Y., Bloss, M., Oyol, P., Hillamo, R., Asmi, E., Saarikoski, S. Sources and composition of particulate matter in boreal arctic environment next to an active mining area, Boreal Environmental Research, Volume 23, 2018, $105-125$.

Tissari, J., Väätäinen, S., Leskinen, J., Savolahti, M., Lamberg, H., Kortelainen, M., Karvosenoja, N., Sippula, O. Fine particle emissions from sauna stoves: Effects of combustion appliance and fuel, and implications for the Finnish Emission Inventory, Atmosphere, Volume 10, 2019, 775. https://doi.org/10.3390/atmos10120775

Tunved, P., Hansson, H.-C., Kerminen, V.-M., Ström, J., Dal Maso, M., Lihavainen, H., Viisanen, Y., Aalto, P.P., Komppula, M., Kulmala, M. High natural aerosol loading over boreal forests, Science, Volume 312, 2006, 261-263.

Ubl, S., Scheringer, M., Stohl, A., Burkhart, J.F., Hungerbuhler, K. Primary source regions of polychlorinated biphenyls (PCBs) measured in the Arctic, Atmospheric Environment, Volume 62, 2012, 391-399, ISSN 1352-2310, https://doi.org/10.1016/j.atmosenv.2012.07.061. 
UNECE. 1998. The 1998 Aarhus Protocol on Heavy Metals. United Nations Economic Commission for Europe. 33 pp. URL: http://www.unece.org/env/lrtap/hm h1.html, accessed 1.2021 .

UNEP. 2019. http://www.pops.int/Portals/0/download.aspx?d=UNEP-POPS-COPCONVTEXT-2021.English.pdf, accessed 8. 2021.

Uria-Tellaetxe, I., Carslaw, D., 2014. Conditional bivariate probability function for source identification. Environmental Modeling an Software 59, 1-9.

USEPA. 2008. Norris, G., Vedantham, R., Wade, K., Brown, S., Prouty, J., Foley, C. EPA Positive Matrix Factorization (PMF) 3.0 Fundamentals \& User Guide.

USEPA. 2013. National Ambient Air Quality Standards for Particulate Matter. Final rule. Federal Register 78: 3086-3287.

USEPA. 2014. Norris, G., Duvall, R., Brown, S., Bai, S., EPA Positive Matrix Factorization (PMF) 5.0 Fundamentals and User Guide, EPA/600/R-14/108, April 2014, https://www.epa.gov/sites/default/files/2015-02/documents/pmf 5.0 user_guide.pdf, accessed 8.18.2018.

Vestenius, M., Leppänen, S., Anttila, P., Kyllönen, K., Hatakka, J., Hellén, H., Hyvärinen, A., Hakola, H. Background concentrations and source apportionment of polycyclic aromatic hydrocarbons in South-Eastern Finland. Atmospheric Environment, Volume 45, 2011, 33913399.

Virkkula, A., Aurela, M., Hillamo, R., Mäkelä, T., Pakkanen, T., Kerminen, V.-M., Manhaut W., Francois F., Cafmeyer J. Chemical composition of atmospheric aerosol in the European subarctic: Contribution of the Kola Peninsula smelter areas, central Europe, and the Arctic Ocean. Journal of Geophysical Research: Atmospheres, Volume 104, No. D19, 1999, 2368123696.

Waldén J., Waldén T., Laurila S. and Hakola H. (2017) Demonstration of the equivalence of PM2.5 and PM10 measurement methods in Kuopio 2014-2015. Finnish Meteorological institute Reports, 1:2017. ISBN 978-952-336-010-5, 135 pp.

Walhout, E.Q., Dorn, S.E., Martens, J., Berden, G., Oomens, J., Cheong, P.H-Y, Kroll, J.H., O'Brien, R.E. Infrared ion spectroscopy of environmental organic mixtures: Probing the composition of $\alpha$-pinene secondary organic aerosol. Environmental Science \& Technology, Volume 53, No. 13, 2019, 7604-7612DOI: 10.1021/acs.est.9b02077

Wängberg, I., Munthe, J. 2001. Atmospheric mercury in Sweden, northern Finland and northern Europe. Results from national monitoring and European research. IVL Swedish Environmental Research Institute. IVL report B1399, 16 pp.

WHO. 2018. Ambient (outdoor) Air Pollution. Key Facts. Fact sheet available at https://www.who.int/news-room/fact-sheets/detail/ambient-(outdoor)-air-quality-and-health, accessed 1.2020.

WHO. 2006. WHO Air Quality Guidelines Global Update 2005, Particulate Matter, Ozone, Nitrogen Dioxide and Sulfur Dioxide, ISBN 9289021926. 
WHO. 2010. The WHO European Centre for Environment and Health, Bonn Office 2010, WHO Guidelines for Indoor Air Quality: Selected Pollutants, ISBN 9789289002134.

Wiedinmyer, C., Guenther, A., Harley, P., Hewitt, N., Geron, C., Artaxo, P., Steinbrecher, R., and Rasmussen, R. Global organic emissions from vegetation. In: Emissions of Atmospheric Trace Compounds, Granier, C., Artaxo, P., Reeves, C.E. (eds.), Kluwer Academic Publishers, Dordrecht, the Netherlands, 115-170, 2004, https://www.euro.who.int/_data/assets/pdf file/0009/128169/e94535.pdf, accessed 8. 2021.

Winiger, P., Andersson, A., Eckhardt, S., Stohl, A., Gustafsson Ö. The sources of atmospheric black carbon at a European gateway to the Arctic. Nature Communications, Volume 7, 2016, 12776.

Wöhrnschimmel, H., Tay, P., von Waldow, H., Hung, H., Li, Y.F., MacLeod, M., Hungerbuhler, K. Comparative assessment of the global fate of !- and àhexachlorocyclohexane before and after phase out, Environmental Science and Technology, Volume 46, 2012, 2047-2054.

Wong, F., Hung, H., Dryfhout-Clark, H., Aas, W., Bohlin-Nizzetto, P., Breivik, K., Mastromonaco Nerentorp, M., Brorström Lundén, E., Ólafsdóttir, K., Sigurðsson, A., Vorkamp, K., Bossi, R., Skov, H., Hakola, H., Barresi, E., Sverko, E., Fellin P., Li, H., Vlasenko, A., Zapevalov, M., Samsonov, D., and Wilson, S. Time trends of persistent organic pollutants (POPs) and Chemicals of Emerging Arctic Concern (CEAC) in Arctic air from 25 years of monitoring, Science of The Total Environment, Volume 775, 2021, 45109, ISSN 0048-9697, https://doi.org/10.1016/j.scitotenv.2021.145109.

Worton, D.R., Decker, M., Isaacman-Vanwertz, G., Chan, A.W.H., Wilson, K.R., Goldstein, A.H. Improved molecular level identification of organic compounds using comprehensive twodimensional chromatography, dual ionization energies and high resolution mass spectrometry, Analyst, Volume 142, 2017, 2395-2403, DOI: 10.1039/C7AN00625J.

Zhao, D., Pullinen, I., Fuchs, H., Schrade, S., Wu, R., Acir, I.-H., Tillmann, R., Rohrer, F., Wildt, J., Guo, Y., Kiendler-Scharr, A., Wahner, A., Kang, S., Vereecken, L., Mentel, T.F. Highly oxygenated organic molecule (HOM) formation in the isoprene oxidation by $\mathrm{NO}_{3}$ radical, Atmospheric Chemistry and Physics, Volume 21, 2021, 9681-9704, https://doi.org/10.5194/acp-21-9681-2021. 


\section{FINNISH METEOROLOGICAL INSTITUTE}

Erik Palménin aukio 1

P.O. Box 503

FI-00560 HELSINKI

tel. +358 295391000

\section{WWW.FMI.FI}

FINNISH METEOROLOGICAL INSTITUTE CONTRIBUTIONS NO. 178

ISSN 0782-6117

ISBN 978-952-336-147-8 (paperback)

ISBN 978-952-336-146-1 (pdf)

https://doi.org/10.35614/isbn.9789523361461

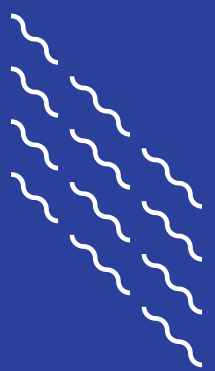

